\title{
APROVEITAMENTO DE RASPA DE MANDIOCA E FARELO DE ARROZ INTEGRAIS NA ALIMENTACÃO DE SUINNOS EM CRESCIMENTO E ACABAMENTO
}

\section{SANDRA MARA CURTARELLI}

Orientador: Prof. Dr. ABEL LAVORENTI

Dissertação apresentada à Escola Superior de Agricultura "Luiz de Queiroz", da Universidade de São Paulo, para obtenção do título de Mestre em Agronomia. Área de concentração: Nutrição Animal o Pastagons.

$P \mid R A C I C A B A$

Estado de São Paulo - Brasil Junho, 1985 
HOMENAGENS :

Prof. Dr. Agenor Cortarelli,

Prof. Dr. Rodolfo Nascimento Kronka,

Prof. Dr. Joji Ariki,

aos quais devemos nossa iniciação à vida profissional e à pes quisa. 
iii.

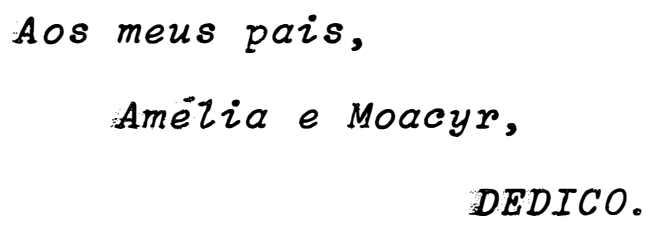

Aos meus irmãos:

Vera Iucia, Angelo Irineu,

Paulo Cësar,

Aos meus cunhados e sobrinhos, OFERECO. 


\section{AGRADECIMENTOS}

A Deus, por ter permitido que cumprỉssemos mais esta etapa em nossa vida.

Ao Prof. Dr. Abel Lavorenti, pela orientação, apoio, amizade e comreensão dedicados durante 0 desenvolvimento deste trabalho.

Ao Departamento de Produção Animal da Faculdade de Ciēncias Agrārias e Veterinārias - "Campus" de Jaboticabal, UNESP, pela oportunidade da realização do Curso de Mestrado.

Aos Profs. Dr. Agenor Cortarell i, Dr. David A. Banzatto, Dr. Sérgio do N. Kronka e Dr. Irineu Humberto Packer, pela colaboração nas anālises estatīsticas dos dados.

As Rações Anhanguera, nas pessoas do Dr. Jūlio J.M. Silveira e CarJos Roberto Viotto Monteiro Pacheco, pelo fornecimento e anāli se bromatológica dos ingredientes das rações experimentais.

A CAPES, pela concessão da Bolsa de Estudos, durante o Curso de Mes trado.

Aos funcionārios do Setor de Suinocultura do Departamento de Produção Animal da Faculdade de Ciências Agrārias e Veterinārias - "Campus" de Jaboticabal, UNESP, pelo auxỉlio na condução prātica da parte experimenta?

Ao Francisco M. Cardoso, pela amizade, dedicação e estīmulo nesses anos de convivência.

A Maria Izalina Ferreira Alves, pela datilografia deste trabalho. 
RESUMO $\ldots \ldots \ldots \ldots \ldots \ldots \ldots \ldots \ldots \ldots \ldots \ldots \ldots \ldots \ldots \ldots \ldots \ldots \ldots \ldots \ldots$

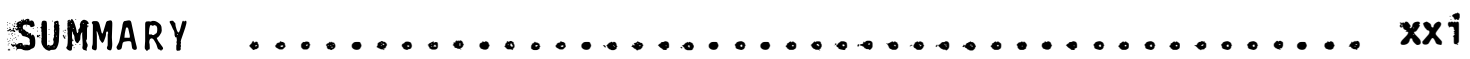

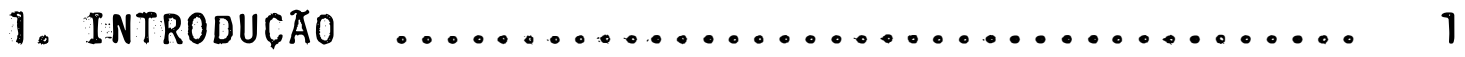

2. REVISÃO DE LITERATURA $\ldots \ldots \ldots \ldots \ldots \ldots \ldots \ldots \ldots \ldots$

2.1 - o Arroz (Oriza sativa L.) ............ 4

2.1 .1 - Estrutura do grão do arroz ..... 7

2.1.2 - Beneficiamento do arroz em casca .. 9

2.1 .3 - Classificacão comercial dos subprodu tos após o beneficiamento do arroz em casca .................. 12

2.1 .4 - 0 farelo de arroz integral ...... 15

2.1.5 - 0 farelo de arroz desengordurado ... 20

2.1.6 - Composição do farelo do arroz ...... 21

2.1.7 - Utilizačão do farelo de arroz na al $\underline{\mathbf{i}}$ mentacão dos suinos............ 26

2.1.7.1 - Desempenho .......... 26

2.1.7.2 - Caracteristicas de carcaca 32

2.2 - A Mandioca (Manihot sculenta Crantz) .... 35

2.2.1 - Colheita, secagem e armazenamento da mandioca ..................... 36

2.2 .2 - Fatores tóxicos ............ 42

2.2.3 - Métodos para reduzir os fatores tóx $\underline{i}$ cos existentes na mandioca.......... 
vi.

Pàg.

2.2.4 - Principais operacões na industrialização da raiz de mandioca e a obtenção dos seus subprodutos ........ 46

2.2.5 - Composição bromatológica da mandioca 48

2.2.6 - Utilização da mandioca na alimentacão dos suĩnos .............. 54

2.2.6.1 - Desempenho ......... 54

2.2.6.2 - Caracteristicas de carcaca 63

3. MATERIAL E METODOS $\ldots \ldots \ldots \ldots \ldots \ldots \ldots \ldots \ldots 6$

3.1 - Instalą̧ões e Equipamentos ........... 68

3.2 - Animais Util izados e Manejo ........... 69

3.3 - Rações Experimentais $\ldots \ldots \ldots \ldots \ldots \ldots .69$

3.4 - Abate dos Animais e Avaliação de Carcaça ... 77

3.5 - Dados de Desempenho e de Carcaca Estudados.. 78

3.5 .1 - Consumo de ração $\ldots \ldots \ldots \ldots \ldots \ldots . . .78$

3.5 .2 - Ganho de peso .............. 79

3.5.3 - Conversão alimentar .......... 79

3.5.4 - Caracteristicas de carcaca ...... 79

3.6 - Delineamento Experimental ........... 79

4. RESULTADOS E DISCUSSAO $\ldots \ldots \ldots \ldots \ldots \ldots \ldots \ldots . \ldots . \ldots 1$

4.1 - Desempenho $\ldots \ldots \ldots \ldots \ldots \ldots \ldots \ldots \ldots . \ldots 1$

4.1 .1 - Consumo de ração $\ldots \ldots \ldots \ldots \ldots \ldots . . .61$ 
vii.

Pāg

4.1.2 - Ganho de peso ............... 93

4.1.3 - Conversão alimentar ............ 105

4.2 - Qualidade de carcaca ................ 112

$5:$ CONCLUSOES $\ldots \ldots \ldots \ldots \ldots \ldots \ldots \ldots \ldots \ldots \ldots \ldots \ldots \ldots \ldots$

6. BIBLIOGRAFIA $\ldots \ldots \ldots \ldots \ldots \ldots \ldots \ldots \ldots \ldots \ldots \ldots \ldots \ldots \ldots \ldots$

7. APENDICE $\ldots \ldots \ldots \ldots \ldots \ldots \ldots \ldots \ldots \ldots \ldots \ldots \ldots \ldots$ 


\section{LISTA DE TABELAS}

TABELA

Pāg.

1 Evolução comparativa da ārea cultivada, produção e rendimento do arroz em casca, no Brasil no perj̃odo de 1974/75 a 1978/79 ...............................

2 Area, produção e rendimento da cultura do arroz no Esta do de São Paulo e na Região Centro. Sul do Brasil, no pe ríodo de $1980 / 81$ a $1982 / 83$...................... 6

3 Aparecimento dos ácidos graxos liures no farelo de arroz e poliduras, em diferentes datas após o processamento do grão do arroz .........................

4 Resultados de tratamentos térmicos no farelo de arroz, em diferentes dias após a obtenção do subproduto .....

$5 \quad$ Nutrientes brutos e coeficientes de digestibilidade do

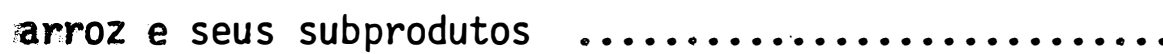

6. Nutrientes digestiveis do arroz e sem s, subprodutos ....

7 Composição em aminoācidos do farelo do arroz ............. 25

8 Influência de diferentes nỉveis de farelo de arroz em raçoes de suinos em fases de crescimento-acabamento

9 Efeitos da substituição do milho pelo farelo de arroz nas fases de crescimento e acabamento 
ix.

TABELA

Pāg.

10 Efeitos da substituição do milho por farelo de arroz no desempenho dos suinos

11 Efeito de diferentes niveis de farelo de arroz sobre o desempenho de suỉnos

12 Efeito da substituição do milho por farelo de arroz, so bre algumas características de carcaça dos suinos ....

13 Area (1.000 ha), produção (1.000 t) e rendimento (kg/ha) de mandioca nos principais paises produtores, no período de 1978 a 1980

14 Area colnida, quantidade produzida, rendimento médio de mandioca nos doze estados brasileiros produtores, no pe rỉodo de 1979 a 1981

15 Dados referentes a ārea plantada (ha), produção $(t)$ e rendimento $(\mathrm{kg} / \mathrm{ha})$ da mandioca no Estado de São Paulo e no Brasil, no período de 1970/78 ................. 39..

16 Area, produção e rendimento de mandioca no Estado de São Pau10, 1980/81 a 1982/83

17 Composição óromatológica de 15 variedades colombianas

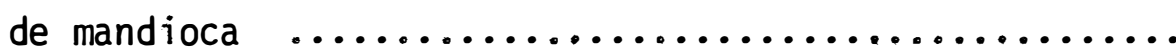

18 Conteūdo de minerais de 10 variedades colombianas de man dioca 
19 Efeito do estágio de maturação e o conteūdo de nitrogēnio total e nitrogênio não protéico das raỉzes de man-

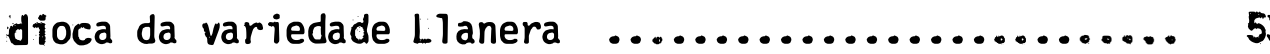

20 Resumo de trabaihos realizados no periodo de 1927 a 1941 , utilizando-se a mandioca como alimento para suīnos .... 54

21 Desempenho dos suĩnos, durante a período experimenta].. 56

22 Desempenho dos suinos, durante 140 dias de experimento

23 Dados referentes a características de carcaça, dos suinos al imentados com milho e farinha de mandioca ......

24 Influência do mitho e na farinha de mandioca sobre o de sempentio dos suinos

25 Características das carcaças de suinos alimentados com ração contendo alto teor de mandioca $(50 \%)$ na forma farelada e prensada

26 Composição quỉmica dos ingredientes $\ldots \ldots \ldots \ldots \ldots \ldots .72$

27 Composição em aminoācidos dos ingredientes $\ldots \ldots \ldots \ldots 73$

28 Composição porcentual das rações experimentais na fase de crescimento

29 Composição porcentual das rações experimentais na fase

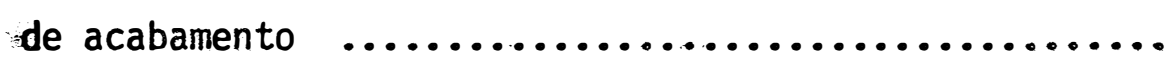


TABELA

Pāg.

30 Composição do suplemento mineral, vitamỉnico, com aditi vos utilizados nas rações experimentais, nas fases de crescimento e acabamento ......................... 76

31 Consumos mëdios de ração $(\mathrm{kg})$ durante o perīodo experimental, nos diferentes tratamentos (médias de 3 animais) 82

32 Consumo total de ração $(\mathrm{kg})$ nas fases de crescimento, acabamento e crescimento-acabamento, durante o periodo experimental

33 Consumos diārios de ração $(\mathrm{kg})$, nos diferentes tratamen tos

34 Quadrados médios obtidos nas anālises de variância dos consumos médios diārios de ração $(\mathrm{kg})$ nas fases de cres cimento, acabamento e crescimento-acabamento ........

35 Pesos médios dos suỉnos $(\mathrm{kg})$ no periodo experimental, nos diferentes tratamentos (médias de 3 animais) ........ 94

36 Ganhos de peso total $(\mathrm{kg})$ dos suinos nas fases de cres cimento, acabamento e crescimento-acabamento

37 Ganho de peso diārio $(\mathrm{kg})$, nos diferentes tratamentos.. 96

38 Quadrados médios obtidos nas anālises de variāncia dos ganhos de peso diärios $(\mathrm{kg})$, nas fases de crescimento, acabamento e crescimento-acabamento 
39 Conversões al imentares médias, durante o perīodo experi mental (médias de 3 animais) $\ldots \ldots \ldots \ldots \ldots \ldots \ldots . . \ldots 6$

40 Conversão al imentar nas fases de crescimento, acabamento e crescimento-acabamento durante 0 periodo experimen tal

41 Quadrados médios obtidos nas anälises de variância das conversões diārias nas fases de crescimento, acabamento e crescimento-acabamento

42 Caracteristicas de carcaça dos animais, nos diferentes tratamentos

43 Médias das caracterîsticas de carcaça, ajustadas por co variāncia para 0 peso de abate $(90,25 \mathrm{~kg}) \ldots \ldots \ldots . .116$

44 Quadrados médios ajustados obtidos nas anālises de variância das características de carcaças com ajustamento por covariância para o peso de abate $(90,25 \mathrm{~kg}) \ldots \ldots 118$ 


\section{LISTA DE FIGURAS}

FIGURA

Pāg.

1 Esquema das estruturas macroscópicas do grão do arroz.. 7

2 Representação esquemática do beneficiamento do arroz ..

3 Representação esquemātica do beneficiamento do grão do arroz

4 Representação, atravēs de histogramas dos con sumos diārios de ração $(\mathrm{kg})$, pelos suínos duran te as fases de crescimento, acabamento e crescimento-aca

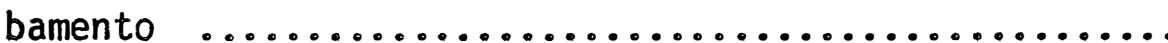

5 Efeitos dos niveis de farelo de arroz integral e de raspa de mandioca integral na ração, sobre o consumo diārio de ração $(\mathrm{kg})$ pelos suĩnos, na fase de crescimen to

6 Efeitos dos nîveis de farelo integral na raçāo, sobre o consumo diārio de ração $(\mathrm{kg})$ dos suīnos, durante a fase de acabamento $\ldots . . \ldots \ldots \ldots \ldots \ldots . . . \ldots . . .$.

7 Efeitos dos niveis de farelo de arroz integral e ras pa de mandioca integral na raçăo, sobre o consumo diário de ração $(\mathrm{kg})$ dos , suĩnos, durante a fase de crescimento-acabamento

8 Representação, atravēs de histogramas dos ga nhos diārios de pesos $(\mathrm{kg})$ pelos suĩnos, durante as fases de crescimento, acabamento e crescimento-aca

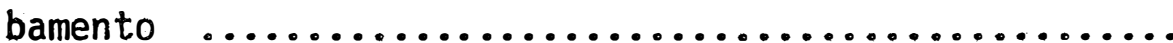


9 Efeitos dos niveis de farelo de arroz integral e ras pa de mandioca integral, sobre o ganho diārio $(\mathrm{kg})$ pelos suinos, durante a fase de crescimento .......... 100

10 Efeitos dos niveis de farelo de arroz integral na ra cão sobre o ganho diärio de peso $(\mathrm{kg})$ pelos suīnos, durante a fase de acabamento

11 Efeitos dos niveis de farelo de arroz integral na ra cão sobre o ganho diārio de peso $(\mathrm{kg})$ pelos suĩnos, durante a fase de crescimento-acabamento

12 Representação, atravēs de histogralias da conversão mē dia, dos suinos durante as fases de crescimento, acaba mento e crescimento-acabamento .................. 108

13 Efeitos dos niveis de farelo de arroz integral na ra cão sobre a conversão al imentar obtida pelo suĩnos, du rante a fase de acabamento..................

14 Representação, atravēs de histogramas, das às caracte rīsticäs de carcaças ........................... 11

15 Efeitos dos niveis de raspa de mandioca integral na racão sobre a espessura de toicinho $(\mathrm{cm})$..............

16 Efeitos dos niveis de raspa de mandioca integral na raçāo sobre a ārea de olho do lombo $\left(\mathrm{cm}^{2}\right)$ 
Xv .

\section{LISTA DO APENDICE}

TABELA

Pāg.

A-1 Consumos de ração $(\mathrm{kg})$ dos animais, no período experimental

A-2 Pesos dos animais $(\mathrm{kg})$ dos tratamentos no período expe rimental

A-3 Ganhos de pesos dos animais $(\mathrm{kg})$, no período experimen tal

A-4 Conversões alimentares dos animais, no período experi mental.

A-5 Pesos de abate e valores auxiliares para avaliação da qualidade da carcaça dos suinnos ............... 150 
$x v i$.

\title{
APROVEITAMENTO DA RASPA DE MANDIOCA \\ E FARELO DE ARROZ INTEGRAIS NA ALIMIENTACĀO \\ DE SUÍNOS EM CRESCIMENTO E ACABAMENTO
}

\author{
Candidata: Sandra Mara Curtarelli \\ Orientador: Prof. Dr. Abel Lavorenti
}

\section{RESUMO}

A presente pesquisa teve como objetivo estü dar a possibilidade da inclusão de diferentes nî́veis de raspa de mandioca e farelo de arroz integrais, em racões isoproteĩcas na alimentação de suínos em fases de cresci mento, acabamento e crescimento + acabamento, e seus efe tos sobre o desempenho e características de carcaca dos anima is

Foram utilizadas 27 fêmeas tri-cross (Lạ ge-White $x$ Wessex $x$ Duroc), distribuidas de acordo com 0 peso em 3 blocos. O delimento experimental foi o de blocos casualizados e 3 repetições, em esquema fatorial com 3 ní veis de substituicão do farelo de arroz integral $(0,15$ e 
xvi

$30 \%)$ e 3 niveis de raspa de mandioca integral $(0,15$ e $30 \%) .0$ s tratamen tes foram: $T_{1}-0 \%$ de raspa de mandioca integral e $0 \%$ de $f \underline{a}$ relo de arroz integral; $T_{2}-15 \%$ de raspa de mandioca inte gra 1; $T_{3}-30 \%$ de raspa de mandioca integral; $T_{4}-15 \%$ de farelo de arroz integral; $T_{5}-15 \%$ de raspa de mandioca in tegral e $15 \%$ de farelo de arroz integral; $\mathrm{T}_{6}-30 \%$ de ras pe de mandioca integral e $15 \%$ de farelo de arroz integral; $T_{7}-30 \%$ de farelo de arroz integral; $T_{8}-15 \%$ de raspa de mandioca integral e $30 \%$ de farelo de arroz integral e $T_{9}$ $30 \%$ de raspa de mandioca integral e $30 \%$ de farelo de arroz integral.

A raspa de mandioca e o farelo de arroz in tegral, substituiram parte do milho e farelo de soja, man tendo os niveis de 15 e $13 \%$ de proteina nas racões de cres cimento $(23,86$ a $58,29 \mathrm{~kg}$ de peso vivo) e acabamento $(58,29$ a $93,47 \mathrm{~kg}$ de peso vivo), respectivamente.

Na fase de crescimento, para os tratamentos de $T_{1}$ a $T_{9}$, foram observados, respectivamente, ganhos diā rios de peso $(\mathrm{kg})$, consumos diärios de racão e conversões al imentares de: 0,$70 ; 0,66 ; 0,60 ; 0,65 ; 0,58 ; 0,60 ; 0,61$; 0,60 e 0,51 e 2,$07 ; 1,87 ; 1,78 ; 1,95 ; 1,68 ; 1,64 ; 1,89$; 1,73 e 1,50 e 2,$94 ; 2,86 ; 2,94 ; 2,97 ; 2,89 ; 2,72 ; 2,85 ;$ 2,90 e 2,93. Nesta fase, embora a raspa de mandioca e o fa relo de arroz integrais não tenham afetado 0 -desempenho 
xvi i i.

dos animais, foram obsevados efeitos lineares e depress $\underline{i}$ vos tanto para consumo diário de racao como para ganho diārio de peso. Para a conversão alimentar não foi observa do efeito significativo $(P>0,05)$ para o farelo de arroz e raspa de mandioca integrais.

Na fase de acabamento, para os tratamentos de $T_{1}$ a $T_{9}$, foram observados, respectivamente, ganhos diā rios de peso $(\mathrm{kg})$, consumos diārios de racão e conversões a 1 imentares de: 0,$86 ; 0,85 ; 0,84 ; 0,72 ; 0,76 ; 0,77 ; 0,73$; 0,71 e 0,64 e 3,$04 ; 2,97 ; 3,10 ; 2,94 ; 2,84 ; 2,92 ; \quad 2,99 ;$ 2,81 e 2,$71 ;$ e 3,$56 ; 3,54 ; 3,68 ; 4,15 ; 3,72 ; 3,77$; 4,13; 3,95 3,95 e 4,29. Nesta fase, embora a raspa de mandioca integral nao tenha afetado o desempenho dos animais, o farelo de arroz integral apresentou efeitos li neares depressivos sobre o consumo diārio de ração $\quad(P<$ $0,05)$, ganho diário de peso $(P<0,01)$ e conversão alimen $\operatorname{tar}(P<0,05)$.

No periodo total (crescimento + acabamento) para os tratamentos de $T_{1}$ a $T_{9}$,foram observados, respecti vamente; ganhos de peso $(\mathrm{kg})$, consumo de racão e conver soes alimentares de: 0,$77 ; 0,75 ; 0,72 ; 0,68 ; 0,66 ; 0,68 ; 0,66$; 0,$65 ;$ e 0,57 e 2,$51 ; 2,37 ; 2,37 ; 2,40 ; 2,20 ; 2,22 ; 2,39$; 2,22 e 2,05 e 3,$25 ; 3,21 ; 3,33 ; 3,52 ; 3,33 ; 3,26 ; 3,65$; 3,42 e 3,61. Nesta fase o farelo de arroz integral apre- 
$x i x$

sentou efeitos lineares depressivos para ganho diārio de peșo $(P<0,01)$ e consumo diārio de racão $(P<0.05)$. A ras pa de mandioca integral apresentou efeitos lineares depres sivos somente para consumo diārio de racão $(P<0,01)$. Não foi observado efeito significativo $(P>0,05)$ sobre a con versão alimentar quando foi incluido a raça o farelo de arroz e raspa de mandioca integrais.

Os dados médios para as caracteristicas de carcaca nos tratamentos de $T_{1}$ a $T_{9}$ foram, respectivamente 77,$89 ; 76,94 ; 76,24 ; 77,05 ; 76,23 ; 75,26 ; 75,78 ; 76,71 \quad$ e $77,60 \%$ para rendimentos de carcaca; 29,57;29,35;29,23 ; 30,$88 ; 32,40 ; 29,70 ; 29,49 ; 32,74$ e $30,41 \%$ para porcenta gem de pernil;91,49;95,87;93,79;94,64;92,28;94,55; 93,77; 94,43 e 92,92 cm para comprimento de carcaca; 3,81; 3,$01 ; 2,93 ; 3,50 ; 2,74 ; 3,03 ; 3,47 ; 2,94$ e $3,30 \mathrm{~cm}$ para es pessura de toicinho; 35,$36 ; 28,94 ; 31,15 ; 34,88 ; \quad 31,88$; 30,$48 ; 35,91 ; 35,24$ e $30,84 \mathrm{~cm}^{2}$ para ärea de olho de $10 \mathrm{mb} 0$ e 0,$69 ; 0,72 ; 0,65 ; 0,64 ; 0,63 ; 0,77 ; 0,58 ; 0,60$ e 0,73 pa ra relação gordura: carne. A inclusão da raspa de mandioca integra 1 à racão apresentou efeito linear depressivo para área de olho de lombo $(P<0,05)$ e efeito quadratico para a espessura de toicinho $(P<0,05)$ ressaltando que, para as dema is $c$ a 
racterísticas de carcaça não foi observado efeito signifi cativo $(P>0,05)$. O farelo de arroz integral não afetou significativamente nenhuma das características de carcaca estudada.

Os resultados do presente estudo, com a in clusão do nĩvel de até $15 \%$ do farelo de arroz ou raspa de mandioca integrais, separados ou em combinações, indicam a possibilidade de utilização dos citados ingredientes nas fases de criação estudadas. Apesar do nível de $30 \%$ do fare To de arroz ou raspa de mandioca integrais, separados ou em combinações quando incluĩdos à ração terem causado efeito prejudicial tanto para desempenho como para a área de olho do lombo e espessura de toicinho, a utilização dos referidos ingredientes em estudo dependerá do custo e dis ponibilidade, quando comparados com os demais alimentos que poderão fazer parte da ração. 
$x x i$.

\section{USE UF CASSAVA MEAL AND RICE BAN IN DIETS FOR GROWING AND FINISHING SWINE}

Author: Sandra Mara Curtarelli

Adviser: Prof. Dr. Abel Lavorenti

\section{SUMMARY}

In this research several levels of cassava meal and rice bran were used in sioproteic diets for growing and finishing pigs.

Twenty seven Large-White $x$ Wessex $x$ Duroc crossbred gilts were alloted on the basis of body weight in three lots to study a factorial $3^{2}$ ( 3 levels of cassava meal and 3 levels of rice bran replacing corn-soybean in the basal diet, following a randomized completely block design with nine treatments and one animal per plot. The treatments were as follow: $T_{1}$ - corn-soybean basal diet; $\mathrm{T}_{2}-15 \%$ cassava meal; $\mathrm{T}_{3}-30 \%$ cassava meal $; \mathrm{T}_{4}-15 \%$ rice bran; $\mathrm{T}_{5}-15 \%$ cassava meal and $15 \%$ rice bran; $\mathrm{T}_{6}$ - 
$x \times i i$

$30 \%$ cassava meal and $15 \%$ rice bran; $T_{7}-30 \%$ rice bran;

$\mathrm{T}_{8}-15 \%$ cassava meal and $30 \%$ rice bran, and $\mathrm{T}_{9}-30 \%$ cassava meal and $30 \%$ rice bran.

Cassava meal and rice bran replaced corn and soyben meal maintaining $13 \%$ and $15 \%$ crude protein in growing diets $(23,86$ to $58,29 \mathrm{~kg}$ BW) and finisghing diets $(52,29$ to $93,47 \mathrm{~kg}$ BW) respectively. the diets were supplemented with vitamins, minerals, antibiotics, and an antioxidant.

In the growing phase daily feed intake was depressed by cassava meal $(P<0,01)$ and rice bran $(P<0,05)$ but there were no effects of these ingredients on average daily gain and feed/gain ratio. Average dayly gain (kg) dally feed intake $(\mathrm{kg})$, and were feed gain/ratio ( $\mathrm{kg}$ ) feed gain/ ratio $0.70,2.07,2.94 ; 0.66,1.87,2.86 ; 0.60,1.78,2.94$; $0.65,1.95,2.97 ; 0.58,1.68,2.89 ; 0.60,1.64,2.72 ; 0.61$, $\therefore 1.89,2.85 ; 0.60,1.73,2.90$ and $0.51,2.93$, respectively for treatments $T_{1}$ through $T_{9}$.

Average daily gain $(P<0,01)$ daily feed intake and feed/gain ratio $(P<0.05)$ were depressed when rice bran was added to finishing diets. Average daily gain $(\mathrm{kg})$, daily feed intake $(\mathrm{kg})$, and feed/ gain ratio were: $0.86,3.04,3.56 ; 0.85,2.97,3.54 ; 0.84,3.10$, $3.68 ; 0.72,2.94,4.15 ; 0.76,2.84,3.72 ; 0.77,2.92,3.77$; $0.73,2.99,4.13 ; 0.71,2,81,3.95$, and $0.64,2.71,4.29$ respectively for treatments $T_{1}$ through $T_{9}$. 
$x \times i i j$

In the growing finishing phase, average daily gain was depressed $(P<0.05)$ by rice bran. Daily ration intake was lower $(P<0.05)$, when cassava meal and rice bran were added to the diets. Feed/gain ratio was not affected $(P>0.05)$ by these ingredients. Average daily gain $(\mathrm{kg})$, daily feed intake $(\mathrm{kg})$ and feed/gain ratio were: $0.77,2.51,3.25 ; 0.75$, $2.37,3.21 ; 0.72,2.37,3.33 ; 0.68,2.40,3.52 ; 0.66,2.20,3.33$; $0.68,2.22,3.26 ; 0.66,2.39,3.65 ; 0.65,2.22,3.42$, and 0.57 , $2.05,3.61$ respectively for treatments $T_{1}$ through $T_{9}$.

Rice bran did not affect $(P<0,05)$ the studied carcass characteristics: dressing percentage, ham percentage, carcass length, back-fac thickness, loin-eye area, and fat/lean ratio. Cassava meal increased $(P<0.05)$ loin-eye area and up to $15 \%$ of cassava meal in the diet reduced 10 in-eye area but an increase was observed in back-fat thickness when the diet contained $30 \%$ of cassava meal. Dressing percentage, ham percentage, carcass length $(\mathrm{cm})$, back-fat thickness $(\mathrm{cm})$, loing-eye area $\left(\mathrm{cm}^{2}\right)$, and fat/lean ratio were: $77.89,29.57$, $91.49 ; 3.81,35.36,0.69 ; 76.94,29.35,95.87 ; 3.01,28.94$, $0.72 ; 76.24,29.23,93.79,2.93,31.15,0.65 ; 77.05,30.88$, $94.64 ; 3.50,34.88,0.64 ; 76.33,32.40,92.28 ; 2.74,31.88,0.63$; $75.26,29.70,94.55 ; 3.03,30.48,0.77 ; 75.78,29.49,93,77$; $3.47,35.91,0.58 ; 76.71,32.74,94.42 ; 2.94,35.24,0.60$; $77.60,30.41,92.92,3.30,30.84$, and 0.73 respectively for treatments $T_{1}$ through $T_{9}$. 
$x x i v$.

The results of this research indicate that rice bran and cassava meal, alone or mixed can be used up to $15 \%$ in diets for growing, finishing and growing-finishing pigs. When rice bran and or cassava meal represented up to $30 \%$ in the diets the performance, loin-yee area, and back-fat thichess were affected. Therefore, their use will depend of availability and costs of other ingredients of the ration.

Adequate levels of cassava meal and rice bran in pig diets should be studied in order to obtain the best economical results, performance, and carcass characteristics. 


\section{INTRODUÇĀO}

0 aumento da populacão humana no mundo resulta em uma crescente demanda de alimentos para satisfazer as necessidades de consumo.

Os cereais, empregados parcialmente na alimen tacão animal, são atualmente utilizados diretamente, em quase sua totalidade, na alimentação humana, sendo cada vez ma is reduzida sua utilização no arroçoamento animal.

Nos países latinoamericanos, hā uma grande tendéncia em se aumentar a produção de alimentos de origem animal, principalmente os de origem suinicola, devendo ser ressaltado que um dos fatores limitantes é a disponibilidade de alimentos que poderiam ser utilizados eficientemente para uma melhor produção de suínos (GOMEZ et alii, 1978). 
Assim os produtores de suínos devem procurar os subprodutos agroindustriais, numa tentativa de reduzir a competicão com o họmem, por alimentos convencionais, tais co mo os cereais. Entretanto, deve-se tomar cuidado na utiliza cão desses subprodutos, para que o desempenho dos animais não seja prejudicado. Por outro lado, um dos fatores que de ve ser considerado como positivo, é o barateamento do custo de produção, no qual a alimentação estā em torno de $80 \%$.

Entre os subprodutos agroindustriais que poderiam ser utilizados na alimentação dos suĩnos, temos o farelo de arroz, resultante do beneficiamento do grão de arroz, e sua disponibilidade está em torno de $10 \%$ do total do grão proces sado. A mandioca tambēm è um dos alimentos que poderia ser utilizada de várias maneiras, como a raiz inteira, raspas, farinha, etc.

Considerando-se que a produção nacional do grão de arroz está em torno de 9.114 .700 toneladas, e a produção da mandioca em cerca de 23,4 milhões de toneladas (PROGOSTICO, 83/84), esses são dois alimentos que merecem ser pesquisados para serem incluĩdos na alimentacão dos suínos. 
O presente trabalho teve por objetivo estudar a possibilidade de utilização dos níveis de farelo de arroz e raspa de mandioca, integrais, em rações de suínos, e seus efeitos no desempenho e características de carcaça. 
4 .

2. REVISAO DE LITERATURA

2.1 - 0 Arroz (Oriza sativa L.)

A producão mundial do arroz em casca, em 1981/82, estimada em 412,2 milhões de toneladas pela Orga nização Mundial para a Agricultura e Alimentação (FAO), apresentou um aumento de $3 \%$ em relaça ao ano anterior e novo recorde de produção (PROGNÓSTICO, 83/84).

Na Tabela 1 pode ser observada a evolução comparativa da área cultivada, producão e rendimento do arroz em casca, no Brasil, no período de 1974/75 a 1978/79 (PROGNUSTICO, 79/80). 
Tabela 1 - Evolução comparativa da ārea cultivada, produção e rendimento do arroz em casca, no Brasil, no periodo de \$974/75 a $1978 / 79$.

\begin{tabular}{cccc}
\hline ANO & $\begin{array}{c}\text { AREA } \\
(1.000 \mathrm{ha})\end{array}$ & $\begin{array}{c}\text { PRODUCAO } \\
(1.000 \mathrm{t})\end{array}$ & $\begin{array}{c}\text { RENDIMENTO } \\
(\mathrm{kg} / \mathrm{ha})\end{array}$ \\
\hline $1974 / 75$ & $5.221,70$ & $7.537,60$ & $1.444,00$ \\
$1975 / 76$ & $6.587,90$ & $9.560,40$ & $1.451,00$ \\
$1976 / 77$ & $5.908,80$ & $8.940,70$ & $1.513,00$ \\
$1977 / 78$ & $5.551,00$ & $7.242,00$ & $1.305,00$ \\
$1978 / 79 *$ & $5.723,00$ & $8.173,70$ & $1.428,00$ \\
\hline
\end{tabular}

Fonte: PROGNŌSTICO $(1979 / 80)$.

* Dados preliminares.

No Brasil, a producão de arroz em casca na safra de 1980 foi de 9.775 .720 toneladas (ANUARIO ESTATIS TICO DO BRASIL, 1980), sendo os cinco principais produtores os seguintes estados: Rio Grande do Sul, Goiās, Mato Grosso, Mạ *ăna e Minas Gerais. Es ses estados são responsāveis por $72 \%$ da produção total do país. Entretanto, a estrmativa da safra nacional para 1982/83, de arroz em casca, foi de 7,8 milhões de toneladas, informação esta obtida atravēs da Fundação do Instituto Brasileiro de Geografia e Es tatîstica, citado no PROGNOSTICO $(83 / 84)$.

Na Tabela 2 pode ser observada a evolucão comparativa da ārea cultivada, produção e rendimento da 


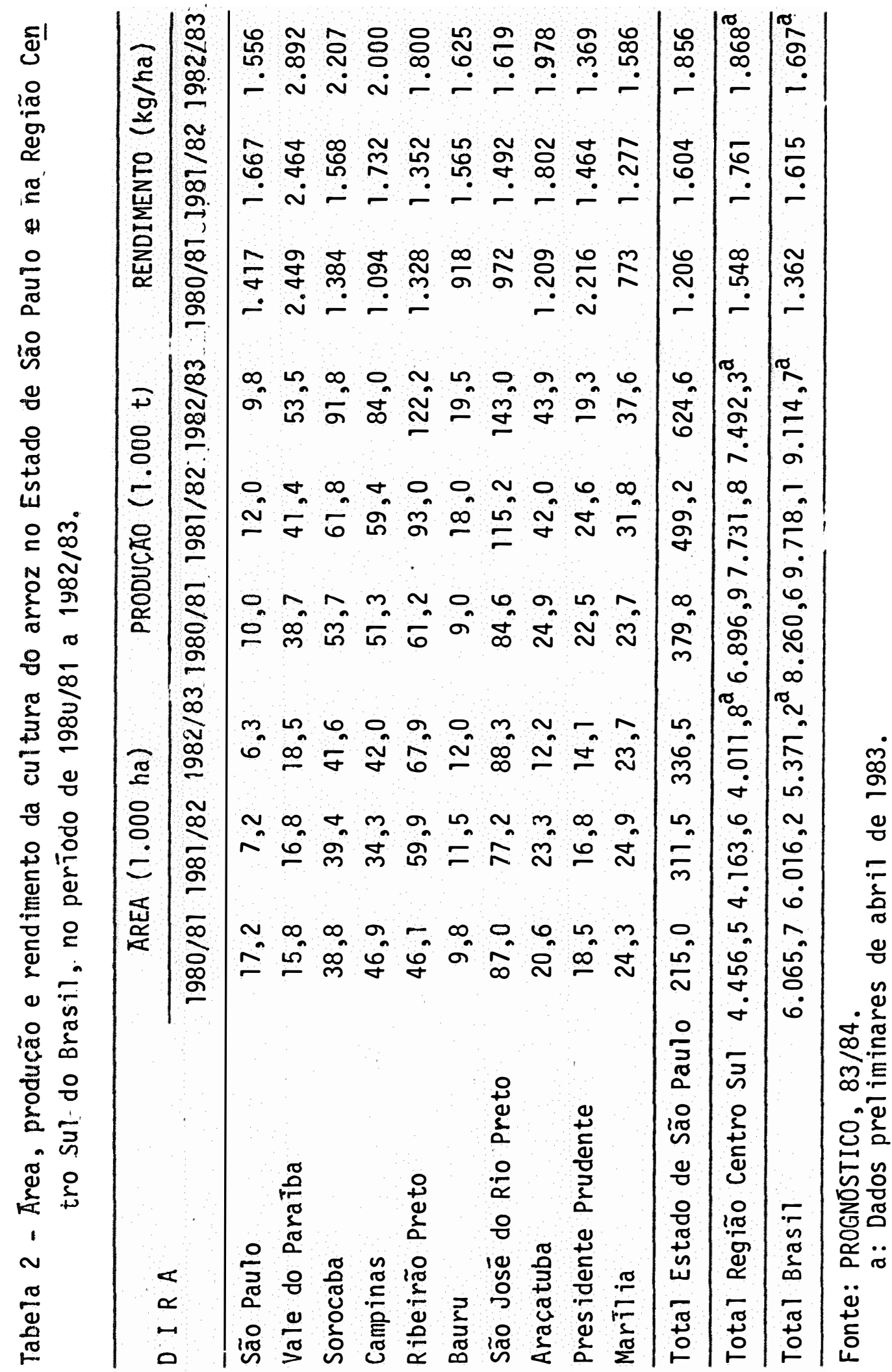


cultura do arroz em casca, obtidas no Estado de São Paulo e Região Centro Sul do Brasil, no período de 1980/81 a 1982/83 (PROGNOSTICO, 83/84).

\subsection{1 - Estrutura do grão do arroz}

Na Frgura 1 podem ser observadas as estrú turas macroscópicas do grão do arroz (Winton e : Winton, 1932, citados por KOK, 1942).

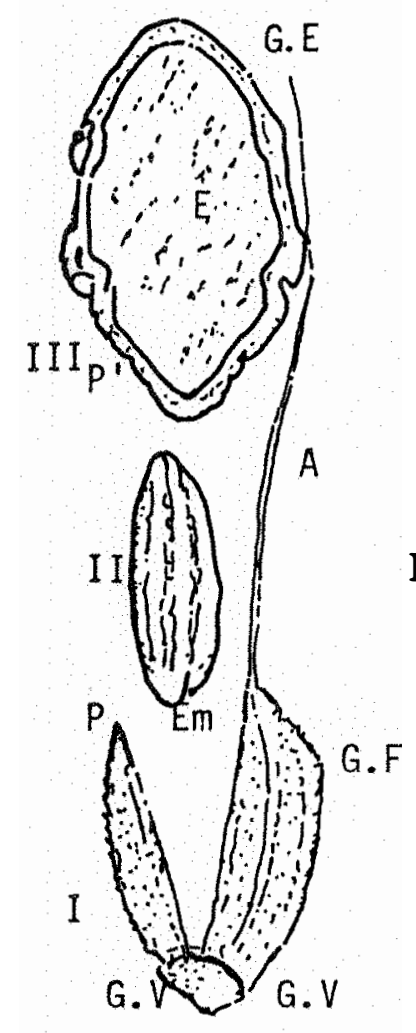

$$
\begin{aligned}
& \text { I - Invōlucros (aumento } \\
& \text { de } 3 \text { vezes) } \\
& \text { II - Grão (aumento de } 3 \\
& \text { vezes) } \\
& \text { III - Seção transversal do } \\
& \text { grão e seus invōlu - } \\
& \text { cros (aumento de } 3 \\
& \text { vezes) } \\
& G . V=\text { glumas vazias } \\
& \text { G.F }=\text { alluma floral } \\
& P=\text { pālea } \\
& A=\text { arista } \\
& \text { Em }=\text { embrião } \\
& G . E=\text { camadas envol } \\
& \text { ventes } \\
& E=\text { endosperma }
\end{aligned}
$$

Figura 1 - Esquema das estruturas macroscōpicas do grão de arroz. 
Segundo Winton e Winton (1932), citados por KOK (1942), o grão de arroz, através de sua estrutura macroscópica, pode ser descrito da seguinte maneira:

- As espiguilhas são formadas por uma única flor, com duas pequenas glumas vazias (G.V.), por uma gluma floral (G.F.), com ou sem arista (A) no āpice e por uma pálea (P) menor. A gluma floral apresenta gera 1 mente cinco nervuras e a pálea (glumula) trēs nervu ras. Observados através de microscópio, os iñvolucros florais mostram uma espécie de desenho cruzado com marcas longitudinais pronunciadas e marcas trans versais mais finas.

- Separadosdas cascas, os grãos (cariópses) (II) são caracterizados por vārios sulcos longitudinais, que sāo formados pelo contato com as saliências da parte interna das glumas florais e da pálea. O embrião está situado na parte inferior, em frente à gluma floral e é relativamente pequeno.

- As camadas que envolvem o endosperma (pericarpo, es permoderma e perisperma) são usualmente designadas pelo nome de peliculas envolventes (C.E.). Essas pe liculas, juntamente com o embrião e parte das cama-das de aleurona e amido do endosperma, constituem 
o farelo grosso, o fino e o extra-fino de arroz. o arroz limpo é formado quase exclusivamente pelo endosperma amiláceo, por pequena porcão das camadas de aleurona e por vestigios das peliculas envolventes e dos germens.

\subsection{2 - Beneficiamento do arroz em casca}

Para ser utilizado na alimentação humana,o arroz bruto, ou seja, o arroz em casca, deve ser beneficiado. O beneficiamento consiste na retirada das cascas e das películas que envolvem os grãos (KOK, 1942).

0 beneficiamento do arroz em casca, segundo KOK (1942), constitui-se essencialmente na retirada gra dual das camadas protetoras do grão do cereal, as quais sáo separadas por jogos de peneiras, obedecendo à seqüēn cia apresentada esquematicamente na Figura 2.

No Brasil existem dois tipos de máquinas beneficiadoras, sendo que uma delas processa o grão de a $\underline{r}$ roz de maneira semelhante ao descrito por KOK (1942), en-

quanto que a do outro tipo é geralmente representada por beneficiadoras pequenas, não apresentando tantas peneiras separadoras, levando a um único tipo de farelo, onde as cascas são moídas com o farelinho e o pó do arroz, dando origem ao farelo grosso de arroz (BRAGA, 1939). 
10.

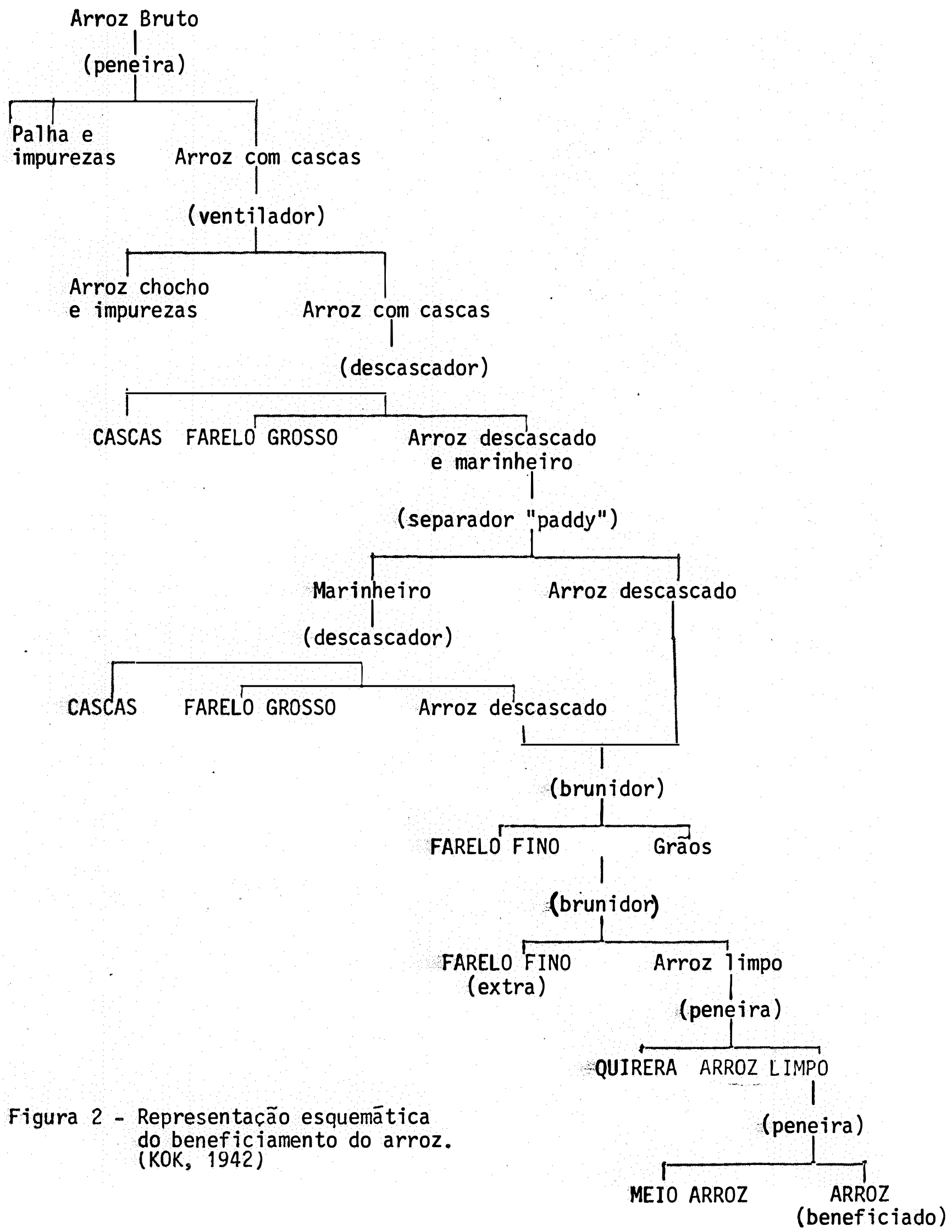


Nas beneficiadoras do primeiro tipo, consi derando que $100 \mathrm{~kg}$ de arroz em casca processados, são obtidos os seguintes produtos e subprodutos: arroz limpo $(60 \mathrm{~kg})$, cascas $(20 \mathrm{~kg})$, farelo grosso $(8 \mathrm{~kg})$, farelo $\mathrm{fi}$ no $(5 \mathrm{~kg})$, meio arroz $(5 \mathrm{~kg})$ e quirera $(2 \mathrm{~kg})(\mathrm{KOK}, 1942)$. Usando-se beneficiadoras do segundo tịpo, obtêm-se os seguintes rendimentos no beneficiamento do arroz em casca, conforme Ribeiro (1983), citado por FONSECA (1984), representado esquematicamente na Figura 3.

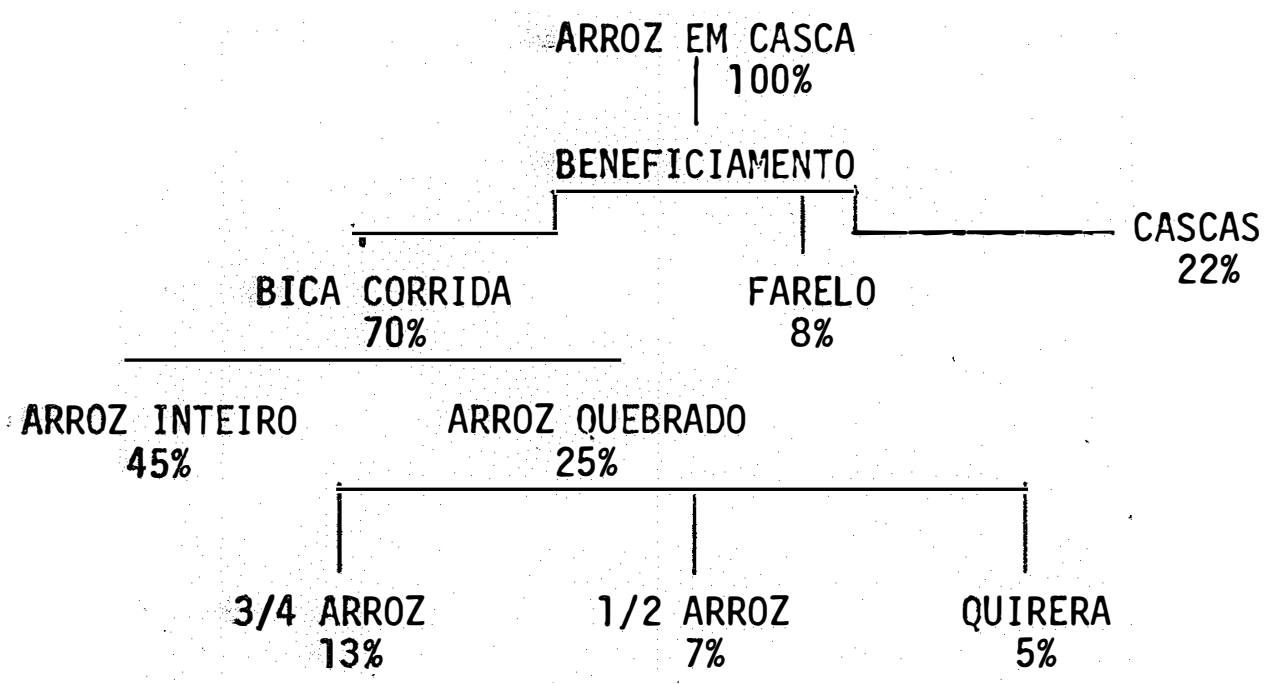

Figura 3 - Representação esquemática do beneficiamento do grão do ar roz (Ribeiro, 1983, citado por FONSECA, 1984). 
Sob o ponto de vista da alimentação humana, existe atualmente a tendéncia a se evitar o brunimen to excessivo do grão do arroz, devido ao fato de que quan do as películas aderentes aos grãos são retiradas,esse ce real perde sua maior fonte de vitaminas do complexo B. En tretanto, o grão do arroz imperfeitamente brunido não é apreciado pelo comércio consumidor, devido sua cor escu ra, ao gosto e à consistēncia que apresenta quando cozido (KOK, 1942).

2.1.3 - Classificação comercial dos subprodutos após o bene ficiamento do arroz em casca

Enquanto o arroz bruto, a quirera e a casca do arroz apresentam composição bromatológica pouco variável, os outros subprodutos tèm composições que diferem bastante entre si. Essas variacões na composicão dos subprodutos devem ser atribuidas, em grande parte, à diversi dade dos processos de beneficiamento do grão do arroz e tambēm às misturas ou a inclusão de outros ingredientes, que levam à adulteração dos subprodutos.

Podem aparecer no comércio numerosas partị das de farelo de arroz cuja composicão bromatológica não corresponde ao que seria de se esperar. Certos fornecedo- 
res de farelos misturam o farelo fino ao grosso, ou adicionam cascas moîdas, colocando à venda subprodutos sob as denominacões de "farelo misturado" ou "farelo do tipo ünico", ou simplesmente "farelo de arroz" (KOK, 1942).

Devido aos fatos acima descritos, 0 Governo do Estado de São Paulo, com o objetivo de padronizar as denominacões dos subprodutos resultantes do beneficiamento do farelo do arroz, através do artigo 120 do Decreto 7.556 , citado por KOK (1942), que dispõe sobre a fisca lização do comércio dos subprodutos, elaborou uma denominação, a qual conceitua os subprodutos da seguinte maneira:

a) Farelo extra-fino ou farelinho extra: é o resīduo do brunimento do arroz no 29 ou 30 brunidor, após a remocão das camadas externas que envolvem os grãos e das cascas, apresentando menos de $3,3 \%$ de fibra bruta.

b) Farelo fino ou farelinho: é o resỉduo do brunimen to do arroz, podendo apresentar uma porcentagem variāvel de pedacos de grãos. Este subproduto deve apresentar de 3,0 a $7,0-7,1 \%$ de fibra bruta na sua composição.

c) Farelo grosso: é o resỉduo mais grosseiro, obtido na remocão das películas que envolvem os grãos, 
podendo conter pedacos pequenos de grāos, germe e uma porcentagem pequena de cascas, podendo apresentar de $7,0-7,1$ a $10,5 \%$ de fibra bruta.

d) Farelo com cascas: é o subproduto do beneficiamen to do arroz, no qual se observa uma regular porcentagem de cascas. Não deve conter mais de $15 \%$ de fibra bruta.

e) Forragem com cascas: é o subproduto no qual se observa uma grande quantidade de cascas, apresentando mais de $15 \%$ de fibra bruta na sua composiçào.

f) Quirera: é o subproduto constituido de fragmentos de grãos, total ou parcialmente limpos.

g) Cascas moídas: é o subproduto da moagem das cascas do arroz.

Levando-se em conta as considerações descritas anteriormente, os diversos subprodutos podem ser reconhecidos através de suas características físicas. Assim, o farelo extra fino apresenta cor branco-amarelada e é muito denso e untuoso ao tato; o farelo fino apresenta caracteristicas semelhantes ao extra-fino, porém é mais escuro e menos macio; o farelo grosso é amarelo ou pardacento-avermelhado, mais áspero ao tato e menos denso que 
- farelo fino; o farelo e a forragem com cascas sáo subprodutos de cor amarelada e palhosa, diferindo entre si pela porcentagem de cascas que contêm (KOK, 1942).

\subsection{4 - 0 farelo de arroz integral}

0 óleo de farelo do arroz pertence ao gru-po dos óleos vegetais, cujos ácidos graxos livres sáo re-presentados por àcidos com 16 e 18 carbonos, contendo uma ou duas duplas ligacões. Cerca de 15 a $20 \%$ de txaido do farelo do arroz.

0 óleo de farelo do arroz é formado predominantemente por triglicerídeos, que são ésteres do glice rol e uma classe particular de ácidos normais,monobásićos e al ifáticos, conhecidos como ácidos graxos. Os ràdicás de ácidos graxos, sendo de alto peso molecular, perfazem a maior parte da molécula do triglicerídeo. Por esta ra-zão, tanto as propriedades químicas como físicas dos óleose gorduras são grandemente determinados pelos ácidos gra xos que eles contêm (FONSECA, 1984).

0 farelo de arroz contém enzimas lipoliticas que se tornam acentuadamente ativas, tão logo o fare10 é removido do arroz. Na presença de umidade os glicerî̉ 
deos da hidrōlise do óleo do arroz passam a glicerol e uma mistura de ācidos livres. Baseando-se nessas condicóes, a rancificação do farelo pode ser causada pela oxidação ou pela ação hidrolitica no óleo que adquire então, odor e sabor desagradāveis. Geralmente, óleos com alto teor em ācidos graxos livres apresentarão odor e sabor de sagradāveis, características associadas com a rancifica cão (ARNOTT e LIM, 1966).

0 aparecimento de ácidos graxos livres no farelo ocorre rapidamente após o processamento do grão do arroz (ARNOTT e LIM, 1966). Na Tabela 3 pode-se observar os resultados obtidos através de anālises de farelo de a $\underline{r}$ roz e poliduras, considerando-se o aparecimento dos ácidos graxos livres, em diferentes dias de coleta. Através dos resultados apresentados na Tabela 3 , os autores constataram que os ācidos graxos livres presentes no farelo de arroz, referente à amostra $B$, aumentaram de 9,2 para $78,0 \%$, após 32 dias de obtenção e na amostra $C$ ocorreu um acréscimo de 5,4 para $46,4 \%$, considerando o mesmo tempo de obtenção do farelo. Com base nessas considerações, os autores ressaltaram que, qualquer que seja o tratamento com o objetivo de se evitar o desenvolvimento dos ácidos graxos livres e consequentemente a deterioracão do farelo, o mesmo deve ser aplicado o mais cedo possivel. 
Tabela 3 - Apareciniento dos ácidos graxos livres no farelo de arroz e poliduras, em diferentes datas após o processamento do grão do arroz.

\begin{tabular}{|c|c|c|c|}
\hline \multirow{2}{*}{$\begin{array}{l}\text { DIAS APOS A } \\
\text { OBTENCAO DOS } \\
\text { SUBPRODUTOS }\end{array}$} & \multicolumn{3}{|c|}{ Expresso com àcido oléico (como \% total do ōleo) } \\
\hline & $\begin{array}{l}\text { Poliduras } \\
\text { Amostra A }\end{array}$ & $\begin{array}{c}\text { Farelo do Arroz } \\
\text { Amostra B }\end{array}$ & $\begin{array}{c}\text { Farelo do Arroz } \\
\text { Amostra C }\end{array}$ \\
\hline 0 & 7,0 & 9,2 & n.d. 17 \\
\hline 1 & 11,8 & 15,8 & n.d. $1 /$ \\
\hline 2 & 15,0 & 19,6 & 5,4 \\
\hline 4 & 20,4 & 26,6 & 9,7 \\
\hline 8 & 29,4 & 38,0 & 75,2 \\
\hline 16 & 40,6 & 51,0 & 24,1 \\
\hline 32 & 68,0 & 78,0 & 46,4 \\
\hline
\end{tabular}

Fonte: ARNOTT e LIM (1966).

$\underline{1} / n_{0}$ = resultado de anālise não obtido.

Com o objetivo de permitir um maior tempo de estocagem do farelo de arroz integral, ARNOTT e LIM (1966) realizaram uma pesquisa submetendo o farelo do arroz às seguintes temperaturas: 105,110 e $120^{\circ} \mathrm{C}$, durante períodos de 3,$0 ; 4,30$ e 6,0 horas. Com base nos resultados obtidos, os autores chegaram às seguintes conclusōes: ocorre perda de peso do farelo, com o aumento da temperatura, associada com o tempo a que foi aquecido e que a temperatura de $105^{\circ} \mathrm{C}$ durante 4,30 horas forneceu uma estimativa satisfatória do conteúdo de umidade do farelo 
e poliduras; os tratamentos por aquecimento foram satisfa tórios no que diz respeito aos impedimentos do desenvolvimento dos ācidos graxos livres, mas, a temperatura de $120^{\circ} \mathrm{C}$ por um periodo de 6 horas, proporciona uma maior segurança pa ra a conservação do farelo.

ARNOTT e LIM (1966) conduziram um outro ex perimento, submetendo o farelo de arroz a temperaturas de 120,160 e $200^{\circ} \mathrm{C}$ durante periodos de 5,15 e 25 minutos, para cada temperatura. Atravēs dos resultados obtidos, ob servaram que o curto período de aquecimento e altas tempe raturas, tornou-se um fator critico, ressaltando que essas temperaturas devem ser cuidadosamente controladas. I to se prende ao fato de que temperatura em torno de $150^{\circ} \mathrm{C}$ não ataca os glicerỉdeos, mas temperatura em torno de $200^{\circ} \mathrm{C}$ ou superior, eleva a hidrólise dos triglicerídeos a glice rol e ācidos graxos o que torna necessārio dar bastante atenção a temperatura a ser utilizada. Os autores concluîram que o perīodo ótimo de aquecimento está em torno de 10 minutos. Os resultados obtidos nesse experimento são mostra dos na Tabela 4. 
Tabela 4 - Resultados de tratamentos térmicos no farelo de arroz, em diferentes dias apōs a obtenção do subproduto.

\begin{tabular}{|c|c|c|c|c|c|c|c|c|c|c|}
\hline \multirow{3}{*}{$\begin{array}{l}\text { DIAS APOS } \\
0 \\
\text { TRATAMENTO }\end{array}$} & \multirow[b]{3}{*}{ (Minúges) } & \multicolumn{9}{|c|}{ Acidos graxos livres (\% do ácido oléico) } \\
\hline & & \multicolumn{6}{|c|}{$\begin{array}{c}\text { Temperatura } \\
160\end{array}$} & \multicolumn{3}{|c|}{200} \\
\hline & & 5 & 15 & 25 & 5 & 15 & 25 & 5 & 15 & 25 \\
\hline & Controle & & & & & & & & & \\
\hline 1 & 3,1 & 3,1 & 3,1 & 3,1 & 3,1 & 3,1 & $3,1 *$ & 3,1 & 3,1 & $3,1^{*}$ \\
\hline 2 & 5,4 & 4,5 & 3,6 & 3,3 & 4,2 & 3,4 & 3,1 & 3,2 & 3,2 & 3,2 \\
\hline 4 & 7,8 & 6,1 & 3,8 & 3,9 & 4,8 & 3,7 & 3,1 & 3,9 & 3,4 & 3,2 \\
\hline 9 & 15,9 & 11,8 & 6,8 & 3,9 & 6,2 & 4,0 & 3,3 & 4,0 & 3,3 & 3,3 \\
\hline 16 & 24,2 & 17,9 & 8,7 & 5,2 & 9,0 & 5,2 & 3,2 & 5,2 & 3,2 & 3,4 \\
\hline 32 & 36,6 & 29,2 & 9,5 & 8,6 & 15,5 & 6,9 & 2,8 & 7,4 & 3,7 & 3,0 \\
\hline
\end{tabular}

Fonte: ARNOTT e LIM (1966).

* Material não controlado nesses tratamentos

Os antioxidantes também são agentes usados na preservaçăo dos ácidos graxos insaturados e das vi taminas lipossolūveis, prevenindo contra a oxidação (KOLB, 1971). Quando o farelo de arroz integral e armazenado sem antioxidantes, ocorre a oxidaçäo dos ácidos graxos e das vitaminas lipossolūveis. Esta reaçao é catalizada pelos minerais presentes no farelo ...der.arroz integral. Para estabilizar os componentes sensiveis à oxidação, a adição de antioxidantes se reveste de grande importáncia. Os antioxidantes proporcionam economia de vitamina $E$ e evitam 
a ocorrēncia de alteracões no odor e sabor dos alimentos (KOLB, 1971).

Considerando-se a nivel de grandes fabrican tes de ração, os antioxidantes utilizados são: o etoxiquim (6-etoxi-2,2,4-trimetil-1,2 dihidroquinidina); O BHA (butil-hidroxi-aiosil), O BHT (butil-hidroxi-tolueno) e o DPPD (difenil-parafenileno-diamina) os quais são eficazes quando as rações ou ingredientes são armazenados . O BHT é util izado na dosagem de $125 \mathrm{~g} / \mathrm{t}$ quando o alimento possui menos de $3 \%$ de óleo, na dosagem de $250 \mathrm{~g} / \mathrm{t}$ para alimentos com mais de $3 \%$ de óleo e na dosagem de $500 \mathrm{~g} / \mathrm{t}$ para estabilizar gorduras e óleos durante o armazenamento. 0 etoxiquim é utilizado na dosagem de $125 \mathrm{~g} / \mathrm{t}$ e O BHA na dosagem de $400 \mathrm{~g} / \mathrm{t}$ de alimento (KOLB, 1971). Em geral, os antioxidantes são utilizados em dosagens que variam entre 50 a $500 \mathrm{~g} / \mathrm{t}$ de alimento (PACHECO, 1979).

\subsection{5 - o farelo de arroz desengordurado}

Segundo ARNOTT e LIM (1966), os farelos de arroz de boa qualidade apresentam de 15 a $20 \%$ de óleo. 0 oleo do farelo de arroz pode ser extraido comercialmente usando-se hexana, obtendo-se, dessa forma, o farelo de a $\underline{r}$ roz desengordurado. Esse sub-produto é utilizado nas ra- 
cões dos animais, tendo a vantagem de ser de mais fäcil conservação.

\subsection{6 - Composição do farelo do arroz}

A composicão bromatológica dos subprodutos resultantes do processamento do grão do arroz foi estudada por vārios autores, os quais concluỉram que a composição e, conseqüentemente, o valor nutritivo pode ser al terado atravēs da inclusão de cascas de arroz moĩdas,as quais apresentam elevado teor em celulose e silica (TORRES, 1949; VIANA, 1956 e MAYMONE et alii, 1962).

VELLOSO (1962) e FONSECA (1984) ressaltaram que a composicão dos subprodutos do arroz pode variar dependendo da variedade do arroz, condicões ecológicas em que foi instalada a cultura, grau de extração no brunimen to, ou seja, tipo de processamento utilizado no beneficia mento do grão do arroz.

Com o intuito de conhecer o real valor nutritivo do arroz e dos subprodutos do arroz, vários estudos foram feitos por KOK (1942), os quais permitiram chegar aos valores em nutrientes brutos e coeficientes de di gestibilidade, cujos resultados são apresentados na Tabe1a 5. Deve-se ressaltar que os coeficientes de digestibi- 


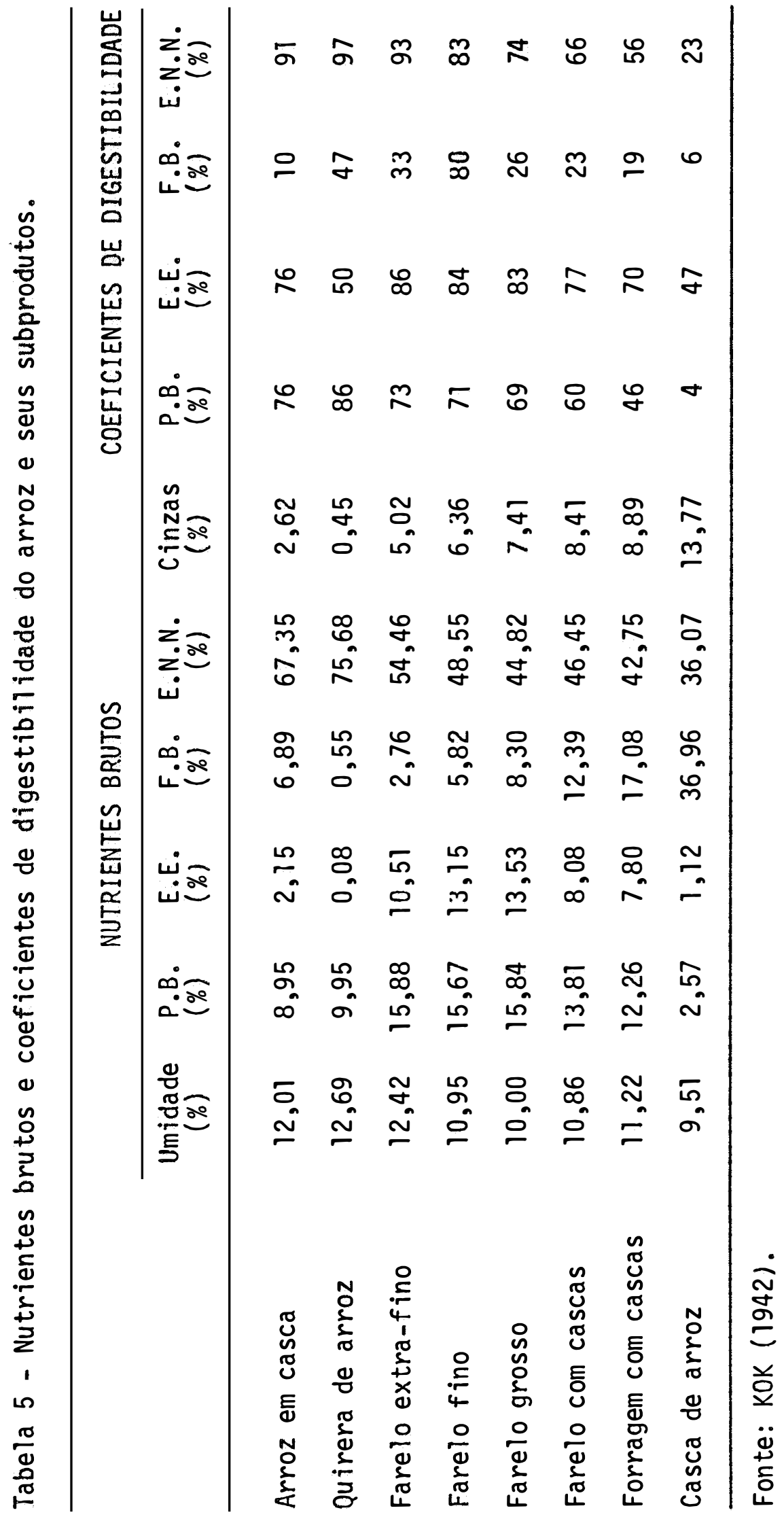


Didade do arroz em casca. do farello extra fitio, do fareIo grosso das cascas, são baseados em morrisom, cittados por KOK (1942). Os resultados são apresemtados ma Tabela 6.

Tabeia 6 - Nu trientes digestiveis do arroz e seus subprodu tos.

\begin{tabular}{|c|c|c|c|c|c|}
\hline \multirow[b]{2}{*}{$\begin{array}{l}\text { SUBPRODUTOS DE } \\
\text { BENEFICIAMENTO } \\
\text { DO GRAO DO ARROZ }\end{array}$} & \multicolumn{4}{|c|}{ NUTRIENTES DIGESTIVEIS (\%) } & \multirow{2}{*}{$\begin{array}{l}\text { Mutrien- } \\
\text { tes Di- } \\
\text { gestiveis } \\
\text { Jotais } \\
\text { (NDT) (\%) }\end{array}$} \\
\hline & Proteîna & $\begin{array}{l}\text { Extrato } \\
\text { Etereo }\end{array}$ & Fibra & $\begin{array}{l}\text { Extrati- } \\
\text { vos não } \\
\text { nitroge- } \\
\text { nados }\end{array}$ & \\
\hline Arroz em casca & 6,80 & 1,68 & 0,69 & 61,29 & 72,45 \\
\hline Quirera de arroz & 8,50 & 0,34 & 0,26 & 73,41 & 82,43 \\
\hline Farelo extra-fino & 11,56 & 9,04 & 0,91 & 50,65 & 81,59 \\
\hline Farelo fino & 11,13 & 11,05 & 1,60 & 40,30 & 77,89 \\
\hline Farelo grosso & 10,58 & 11,23 & 2,16 & 33,17 & 71,18 \\
\hline Fare10 com cascas & 8,29 & 6,22 & 2,85 & 30,66 & 55,79 \\
\hline forragem com cascas & 5,64 & 5,46 & 3,24 & 23,94 & 45,10 \\
\hline Cascas do arroz & 0,00 & 0,53 & 2,22 & 8,30 & 11,81 \\
\hline
\end{tabular}

Fonte: KOK (1942).

Estudando a composição bromatológica do fa relo do arroz, BRAY (1943) obteve aproximadamente 12\% de proteina bruta, $15 \%$ de extrato etéreo, $12 \%$ de fibra bruta, $40 \%$ de extrativos não nitrogenados e $84 \%$ de nutrientes digestiveis totais. Resultados semelhantes foram ob- 
servados por MORRISON (1966), obtendo, atravēs de anālise, valores de $12,4 \%$ de proteina bruta, $13,6 \%$ de extrato etéreo e $11,6 \%$ de fibra bruta.

JULIANO (1972) observou que a relacão cālcio:fósforo do farelo de arroz é muito baixa $(1: 10)$, considerando como desejāvel 1:1. O fósforo $(21,4 \%)$ é o componente mais abundante na matéria mineral do farelo, seguido do potássio $(18,0 \%)$, magnésio $(10,4 \%)$. Os demais mi nerais apresentam-se em menor quantidade como o cálcio, sódio, ferro, cloro e aluminio. 0 autor ressalta ainda que as tabelas de composicão da proteina do farelo, em aminoācidos, apresentam discrepāncias às vezes muito gran des, devidas, principalmente, às diferentes condicões de hidrōlise utilizadas pelos pesquisadores. Na Tabela 7 podem ser observados, segundo JULIANO (1972), os valores médios dos aminoácidos no farelo de arroz.

$$
\text { Referindo-se aos lipideos, FONSECA }
$$

relata que o farelo integral apresenta cerca de $16 \%$ de 1 i pídeos e o desengordurado tem 0,5 a $1,0 \%$. 0 farelo integral é energeticamente melhor, pois o óleo presente resulta num maior potencial calorifico, observando que o óleo pode fornecer $9,5 \mathrm{Kcal} / \mathrm{g}$, enquanto que os carboidratos apenas $4,0 \mathrm{Kcal} / \mathrm{g}$. O farelo de arroz desengordurado é nutricialmente melhor, pois o teor de proteina aumenta pro 
Tabela 7 - Composição em aminoācidos do farelo do arroz.

\begin{tabular}{lc}
\hline AMINOACIDO & $\mathrm{g} / 16,8 \mathrm{~g}$ de Nitrogēnio \\
\hline Alanina & 7,10 \\
Arginina & 6,10 \\
Acido aspärtico & 9,60 \\
Acido glutâmico & 16,80 \\
Cistina & 1,20 \\
Fenilalanina & 6,10 \\
Glicina & 4,10 \\
Histidina & 1,40 \\
Isoleucina & 4,90 \\
Leucina & 9,20 \\
Lisina & 4,20 \\
Prolina & 5,20 \\
Serina & 5,20 \\
Tirosina & 5,00 \\
Treonina & 3,30 \\
Triptofano & 1,40 \\
Valina & 5,60 \\
\hline
\end{tabular}

Fonte: JULIANO (1972).

porcionalmente com a extracäo do 01 eo. 0 autor ressalta que o farelo é uma excelente fonte de vitaminas do complexo B e de vitamina E. Entretanto, as vitaminas A (provitami nas), C e D são escassas. A vitamina E é extraída juntocom - óleo, e o farelo desengordurado fica muito pobre nesse nu triente. 
2.1.7 - Util ização do farelo de arroz integral na al imentação dos suĩnos

\subsubsection{1 - Desempenho}

Ainda é pequeno o número de trabalhos visando à utilização do farelo de arroz na alimentação dos suinos. Entretanto, pode ser considerado como um ingrediente de boa qualidade, para ser incluído nos vārios tipos de racões para os animais. Os estudos realizados são insu ficientes para uma indicacão segura dos nỉveis do farelo de arroz integral ou desengordurado que podem ser utiliza dos nas diversas fases da vida dos suinos.

BRAY (1943) utilizou o milho e o farelo de

arroz integral como fonte de energia em rações de suĩnos. Con tatou que os melhores ganhos de peso foram obtido pelos animais que receberam ração contendo $75 \%$ de milho e $25 \%$ de farelo de arroz como fonte de energia, ressaltando que a racão mais econōmica foi a que apresenta o suplemento composto de $70 \%$ de milho e $30 \%$ de farelo de arroz.

DURAN (1959) constatou que o farelo de arroz substituiu omilho satisfatoriamente em racões de suínos, proporcionando os melhores ganho de peso e convérsão alimentar. Esses resultados confirmaram os dadós apresen- 
tados por CUNHA (1957), MORRISON (1966) e PINHEIRO MACHADO (1967). VIANA (1956) reportou que em racões de suinos o farelo de arroz, substituindo até $50 \%$ do milho, não afe tou o desempenho dos animais.

NOLAND et alii (1960), estudando a substituicão do milho pelo farelo de arroz, numa raça constituída basicamente de milho, farelo de soja e gordura animal estabilizada, obtiveram bons resultados de desempenho até o nível de substituicão de $40 \%$ do milho por farelo de arroz. Ressaltaram ainda que, acima desse nivel ocorreu menor ganho de peso e pior conversão alimentar.

COMBS (1961) relatou que o farelo de arroz integral não deve ser incluỉdo em rações de suinos em níveis superiores a 30 ou $40 \%$ do total da racão, considerando-se que esse alimento apresenta altos teores em ácidos graxos, ocasionando a rancificacão e proporcionando uma raço pouco palatável.

Segundo estudos realizados por NOLAND e SCOTT (1963), o farelo de arroz é um alimento que ocasiona resultados negativos no desempenho dos suinos quando esse subproduto substitui o mil ho em niveis crescentes, ou seja, em até $100 \%$. Os resultados obtidos são mostrados na Tabela 8. 
Tabela 8 - Influencia de diferentes nỉveis de fareío de arroz em rá ções de suĩnos em fases de crescimento-acabamento.

\begin{tabular}{|c|c|c|c|c|c|}
\hline \multicolumn{2}{|c|}{ Niveis de substituicão } & o milho & \multicolumn{2}{|c|}{ pelo farelo de } & $\operatorname{rroz}(\%)$ \\
\hline & 0 & 25 & 50 & 75 & 100 \\
\hline so médio inicial $(\mathrm{kg})$ & 23,00 & 20,00 & 21,00 & 20,00 & 20,00 \\
\hline eso mëdio final $(\mathrm{kg})$ & 89,60 & 88,20 & 87,80 & 79,60 & 70,90 \\
\hline ianho médio diārio (kg) & 0,81 & 0,80 & 0,75 & 0,66 & 0,57 \\
\hline Consumo médio diārio $(\mathrm{kg})$ & 2,63 & 2,73 & 2,67 & 2,57 & 2,16 \\
\hline Conversão al imentar & 3,23 & 3,41 & 3,58 & 3,87 & 3,77 \\
\hline
\end{tabular}

Fonte: NOLAND e SCOTT (1963).

NUGARA (1966), pesquisando a utilização do farelo do arroz na alimentacão de suínos em fase de crescimento, obteve resultados satisfatórios para ganho de pe so, qando este subproduto substitui o milho em atè $30 \%$.

TRASHER et alii (1966) reportaram que a substituicão de 20 e $30 \%$ do milho por farelo de arroz em dieta constituida de milho e farelo de soja, para suinos, Jevou a uma reducão de ganho de peso em 8 e $15 \%$ respectivamente.

ROJAS E BRAVO (1971) conduziram um experimento com suínos, os quais foram alimentados com ração à base de milho e farelo de soja, onde o milho foi substituĩdo em $0 \%, 7,5 \%, 15,0 \%, 22,5 \%$ e $30,0 \%$ pelo farelo de ar 
roz, na fase de crescimento. Na fase de acabamento o miTho foi substituido em $0 \%, 15,0 \%, 30,0 \%, 45,0 \%$ e $60,0 \%$. Os resultados obtidos nas duas fases são apresentados na Tabela 9. Considerando os dados obtidos, os autores conclui

Jabela 9 - Efeitos da súbstituição do milho pelo farelo de arroz nas racões de suĩnos em fases de crescimento e acabamento.

\begin{tabular}{|c|c|c|c|c|c|c|}
\hline \multirow{2}{*}{$\begin{array}{l}\text { Indices } \\
\text { Controlados }\end{array}$} & \multicolumn{6}{|c|}{ Niveis de substituição do millho pelo farelo de arroz(\%) } \\
\hline & & 0,0 & 7,5 & 15,0 & 22,5 & 30,0 \\
\hline & & \multicolumn{5}{|c|}{ FASE DE CRESCIMENTO } \\
\hline Peso médio & icial $(\mathrm{kg})$ & 15,80 & 16,30 & 17,00 & 16,80 & 16,20 \\
\hline Ganho diāric & (kg) & 0,445 & 0,432 & 0,459 & 0,484 & 0,372 \\
\hline Consumo diar & $0(\mathrm{~kg})$ & 1,48 & 1,34 & 1,55 & 1,53 & 1,39 \\
\hline \multirow{3}{*}{\multicolumn{2}{|c|}{ Conversão al imentar }} & 3,33 & 3,10 & 3,38 & 3,16 & 3,74 \\
\hline & & 0,0 & 15,0 & 30,0 & 45,0 & 60,0 \\
\hline & & \multicolumn{5}{|c|}{ FASE DE ACABAMENTO } \\
\hline Peso médio & icial $(\mathrm{kg})$ & 40,70 & 40,50 & 42,70 & 43,90 & 37,00 \\
\hline Ganho médio & iārio (kg) & 0,746 & 0,729 & 0,688 & 0,736 & 0,620 \\
\hline Consumo méd & diārio $(\mathrm{kg})$ & 2,97 & 2,55 & 2,55 & 2,45 & 2,17 \\
\hline Conversão al & mentar & 3,98 & 3,50 & 3,71 & 3,33 & 3,44 \\
\hline
\end{tabular}

Fonte: ROJAS e BRAVO (1971).

ram que o farelo de arroz pode substituir o milho em até $22,5 \%$ na fase de crescimento e $45 \%$ na de acabamento.

CHICCO et alii (1974) substituíram o milho por polidura de arroz em niveis de $0,0,33,0,66,0$ e $100,0 \%$. 
em racões para suĩnos. Os dados obtidos são apresentados na Tabela 10. Através dos resultados observados, os autores não encontraram diferencas significativas entre os tra tamentos, concluindo que a polidura de arroz pode substituir totalmente o milho na racão, sem prejuízos no desempenho dos animais.

Tabela 10 - Efeitos da substituição do milho por farelo de arroz no desempenho dos suĩnos.

\begin{tabular}{lrrrr}
\hline & \multicolumn{4}{l}{$\begin{array}{l}\text { Niveis de substituição do milho pela polidu } \\
\text { ra de arros }(\%)\end{array}$} \\
\cline { 2 - 5 } INDICES CONTROLADOS & \multicolumn{1}{c}{0,0} & \multicolumn{1}{c}{33,0} & 66,0 & 100,0 \\
\hline Peso inicial (kg) & 38,000 & 38,200 & 38,300 & 38,200 \\
Peso final (kg) & 90,800 & 89,800 & 85,200 & 89,000 \\
Ganho diārio (kg) & 0,880 & 0,861 & 0,781 & 0,847 \\
Conversão al imentar & 3,700 & 3,800 & 4,100 & 3,800 \\
\hline
\end{tabular}

Fonte: CHICCO et alii (1974).

Com a finalidade de verificar o valor nutritivo do farelo de arroz, SHARDA et alii (1977) desenvolveram um experimento com suínos em fase de crescimento, levando em conta o nível de farelo de arroz integral $(0,15$ e $30 \%$ ) em substituição ao milho no desempenho dos animais. os resultados obtidos são mostrados na Tabela 11 , e permi tiram aos autores concluirem que a té o nível de $15 \%$ de 
substituicão, o farelo de arroz não afetou o desempenho dos suinos. Entretanto, o nīvel de $30 \%$ de substituição resultou em reducão do ganho de peso, do consumo de racão e da eficiēncia alimentar.

Tabela 11 - Efeito de diferentes nïveis de farelo de arroz sobre o desempenho de suĩnos.

\begin{tabular}{lccc}
\hline & \multicolumn{3}{c}{$\begin{array}{c}\text { Níveis de substituicão do milho } \\
\text { pelo farelo de arros }(\%)\end{array}$} \\
\cline { 2 - 4 } INDICES CONTROLADOS & 0,0 & 15,0 & 30,0 \\
\hline Peso inicial (kg) & 14,400 & 13,900 & 14,700 \\
Peso final (kg) & 42,700 & 41,200 & 29,600 \\
Ganho diärio (kg) & 0,367 & 0,356 & 0,194 \\
Consumo diārio (kg) & 1,320 & 1,380 & 0,780 \\
Eficiēncia alimentar & 0,278 & 0,257 & 0,246 \\
\hline
\end{tabular}

Fonte: SHARDA et alii (1977).

MOURA et alii (1982) estudaram a possibili dade da utilização de altos níveis de farelo de arroz no arracoamento de suinos, em fases de crescimento-acabamento, submetidos aos seguintes tratamentos: $T_{1}=0 \%$ (testemunha), $T_{2}=50 \%$ e $T_{3}=100 \%$ de substituicão do milho por farelo de arroz integral. Os ganhos mēdios diārios de peso foram: $T_{1}=0,706 \mathrm{~g} ; T_{2}=0,677 \mathrm{~g} \mathrm{e} T_{3}=0,528 \mathrm{~g}$, e a conversão alimentar $3,78,3,78$ e 4,33 , respectivamente, 
não apresentando diferenças estatisticamente significativas entre os dois primeiros tratamentos, mas foram dife-rentes do 30 a o nível de $5 \%$ de probabilidade.

\subsubsection{Características de carcaça}

Alguns trabalhos têm sido realizados com o objetivo de estudar os efeitos da substituição do milho por farelo de arroz ou outras fontes energēticas, sobre as características de carcaca dos suĩnos.

CHICCO et alii (1974) estudaram o efeito da substituição do milho por farelo de arroz, em niveis de 0,33 , 66 e 100\%. Analisando os resultados obtidos e apresentados na Tabela 12, os autores não observaram diferenças es tatisticas entre os tratamentos. Entretanto, verificaram que à medida em que o nível de substituicão foi aumentan do, houve uma tendēncia a se obter carcaças de qualidade inferior comparando-se com a testemunha.

PINEDA et alii (1975) substituiram o milho por farelo de arroz integral, em niveis de $0,20,40,60$ e $80 \%$, com o objetivo de verificar os seus efeitos sobre 
Tabela 12 - Efeito da substituição do milho por farelo de arroz, sobre algumas características de carcaça dos suĩnos.

\begin{tabular}{lrrrr}
\hline \multirow{2}{*}{ OBSERVAÇES } & \multicolumn{3}{c}{$\begin{array}{c}\text { Níveis de substituicão do milho } \\
\text { pelo farelo de arroz }\end{array}$} \\
\cline { 2 - 5 } & 0,0 & 33,0 & 66,0 & 100,0 \\
\hline Peso da carcaça $(\mathrm{kg})$ & 72,80 & 71,10 & 69,10 & 68,90 \\
Rendimento da carcaça $(\mathrm{kg})$ & 80,20 & 79,20 & 81,10 & 77,40 \\
Comprimento da carcaça $(\mathrm{cm})$ & 77,30 & 79,20 & 78,70 & 77,50 \\
Espessura do toucinho $(\mathrm{cm})$ & 4,27 & 3,97 & 3,93 & 4,20 \\
\hline
\end{tabular}

Fonte: CHICCO et alii (1974).

a espessura do toucinho nos suinos. Os autores observaram que $\bar{a}$ medida em que o nỉvel de substituição foi aumentando houve tendēncia em se obter toucinho mais espesso(2,52; $3,10 ; 3,38 ; 4,32$ e 4,51$)$, 1evando a uma depreciação da qua lidade da carcaca.

Com a finalidade de determinar o nivel mais adequado de substituição do milho por farelo de arroz integral, RIBEIRO (1980) relata um trabalho com suinos das raças Piau, Wessex e Mestiços, os quais foram al imentados com rações contendo 0 e $30 \%$ de fare10 de arroz integral, sendo avaliadas as características de car caça. Através dos resultados obtidos, os autores puderam observar que, para rendimento de carcaca, não houve dife- 
renca entre os tratamentos. Entretanto, o tratamento cons tituĩdo por $30 \%$ do farelo apresentou a ārea de 01 ho do 10 m bo inferior ao do tratamento com $15 \%$, principalmente para a raca Wessex. Para a espessura de toucinho, o teste mostrou efeitos negativos para todos os níveis de farelo tes tados. Para comprimento da carcaca, os animais alimentados com racão contendo $30 \%$ do farelo de arroz integral apresentaram resultados inferiores ao com 15\%. Considerando-se as propriedades físico-químicas do toucinho, as anā 1 ises mostraram toucinho de consistēncia mole e de cor amarelada, para os animais alimentados com racáo contendo $30 \%$ de farelo de arroz integral.

MOURA et alii (1982) substituiram o milho por farelo de arroz integral em níveis de 0,50 e $100 \%$ e, apōs o abate dos animais, chegaram aos seguintes resultados: comprimento de carcaca $(\mathrm{cm}): 100,16,100,36$ e 100,14; espessura média de toucinho $(\mathrm{cm}): 2,99,2,92$ e 2,29; ārea do olho do lombo $\left(\mathrm{cm}^{2}\right): 36,53,36,28$ e 37,41 ; peso do per nil $(\mathrm{kg}): 10,94,11,29$ e 10,74 ; porcentagem do perni1(\%): $28,10,28,90$ e 29,00; e teor de gordura no músculo (\%): $1,85,1,52$ e 1,48. Nestas características não foram obser vadas diferenças estatisticamente significativas entre os tratamentos. Foi também analisado o indice do iodo do tou cinho, e os resultados foram $61,47,80,62$ e 91,71 , respec 
tivamente para os niveis de 0,50 e $100 \%$ de substituicão do milho pelo farelo, tendo sido observada diferenca somente entre o nīvel zero e os demais níveis.

\section{2 - A Mandioca (Manihot scuZenta Crantz)}

A mandioca (Manihot scuzenta Crantz) é um alimento que apresenta um grande potencial na alimentação dos suinos, sendo esse potencial ainda pouco conhecido em muitas regiões tropicais. A mandioca pertence à familia Euforbiaceae, gēnero Manihot, o qual apresenta várias espécies e um grande nümero de variedades (GODOY, 1940 e NORMANHA e PEREIRA, 1950). A utilização da mandioca é tradicional na região tropical sul-americana, princi palmente a raiz, que é utilizada tanto na alimentação humana como na alimentação animal (GODOY, 1940; JUAREZ GA LIANO, 1955; Normanha e Pereira, citados por MELOTTI, 1972)

A mandioca apresenta variedades com alto grau de adaptação e resistēncia à seca, a alta precipita cão pluvial anual e a quase todo o tipo de solo,mesmo aos solos pobres, sendo, portanto, um alimento fácil de ser produzido (MANER et azii, s/d). 
os dados referentes à ārea plantada, produ cão e rendimento da mandioca, nos doze países de maior pro ducão, nos Estados Brasileiros, no Estado de São Paulo e Brasil, e nas principais DIRAs do Estado de São Paulo são apresentados nas Tabelas $13,14,15$ e 16, respectivamente. Deve ser salientado que o aumento da produ cão da mandioca no Brasil e no mundo está diretamente relacionado com a utilizaçäo de seus derivados no setor industrial e à crescente substituicão dos grãos de cereais por sub-produtos da industrialização da raiz da imandioca nas fābricas de rações.

\subsection{1 - Colheita, secagem e armazenamento da mandioca}

A mandioca, para ser aproveitada convenien temente, tanto na alimentaça humana como na alimentaça animal, apresenta problemas relacionados com a colheita, o processamento e o armazenamento deste tubérculo.

A raiz a ser colhida apresenta forma bastante irre lar, occupando uma área relativamente grande no solo. Nos solos areno sos ou úmidos, a colheita é uma operaça bastante fácil. Enou ümidos, a colheita é uma operação bastante fācil. Entretanto, os solos compactos ou secos apresentam problemas como a dificuldade em retirar do solo a raiz inteira. 
37.

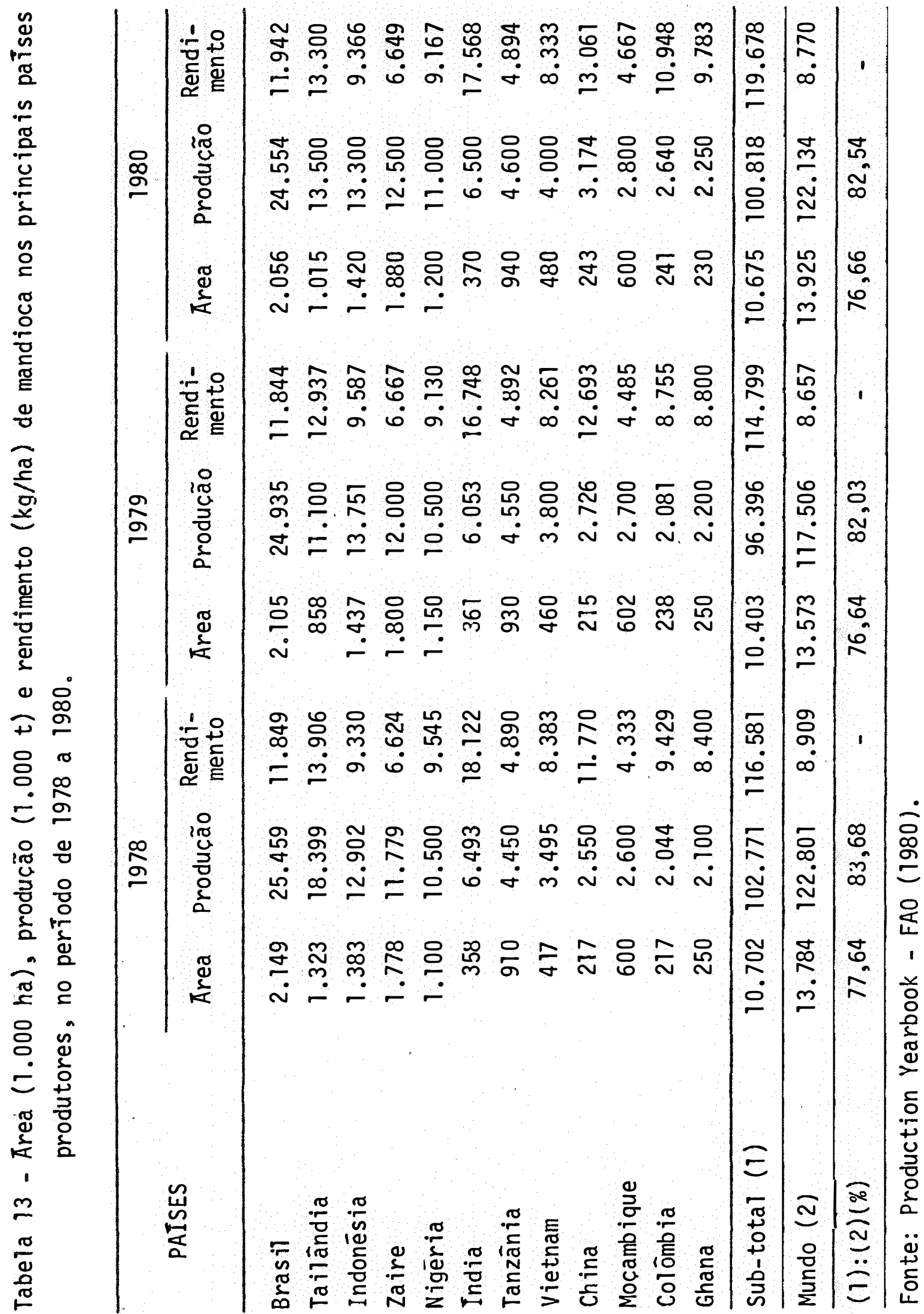




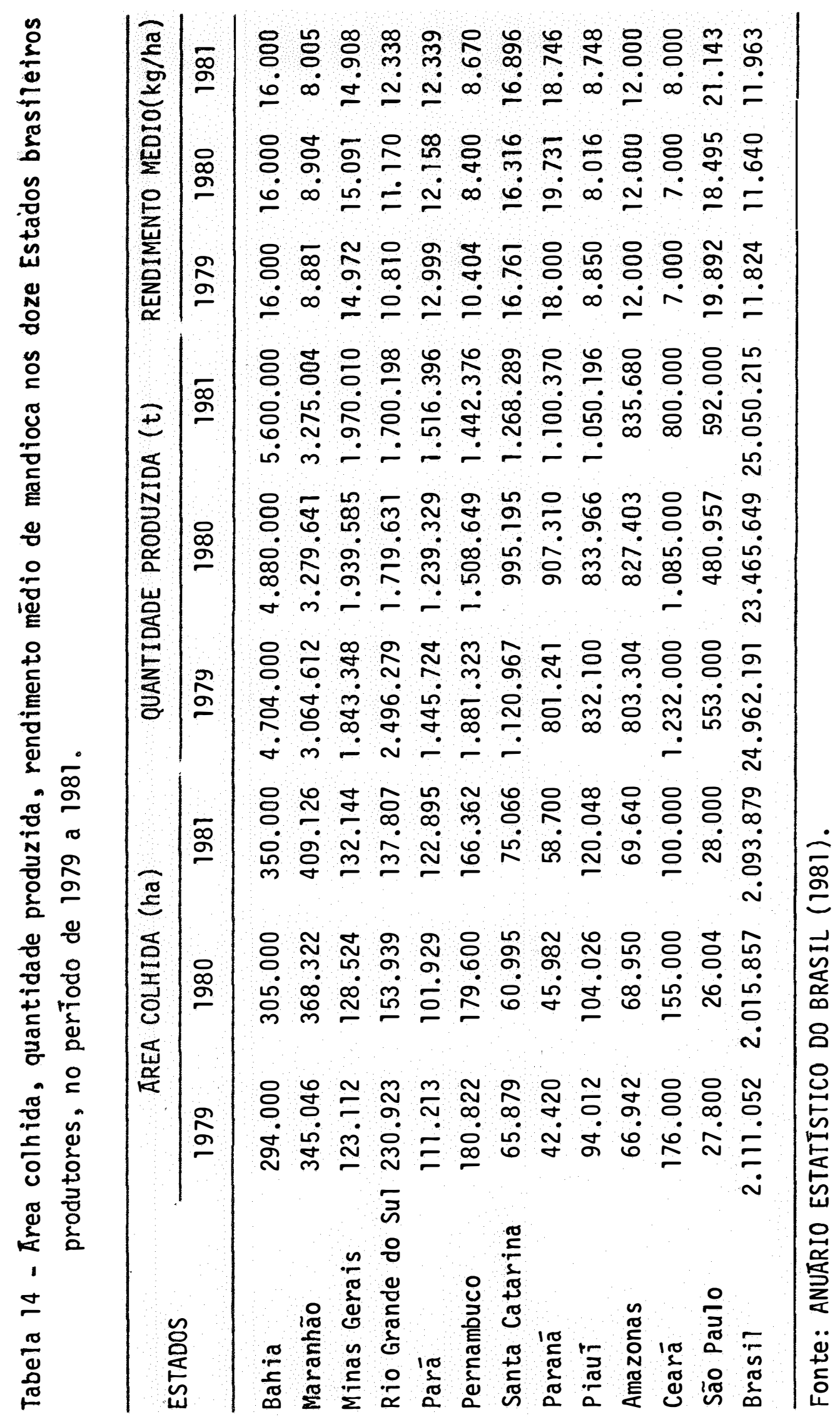

38. 


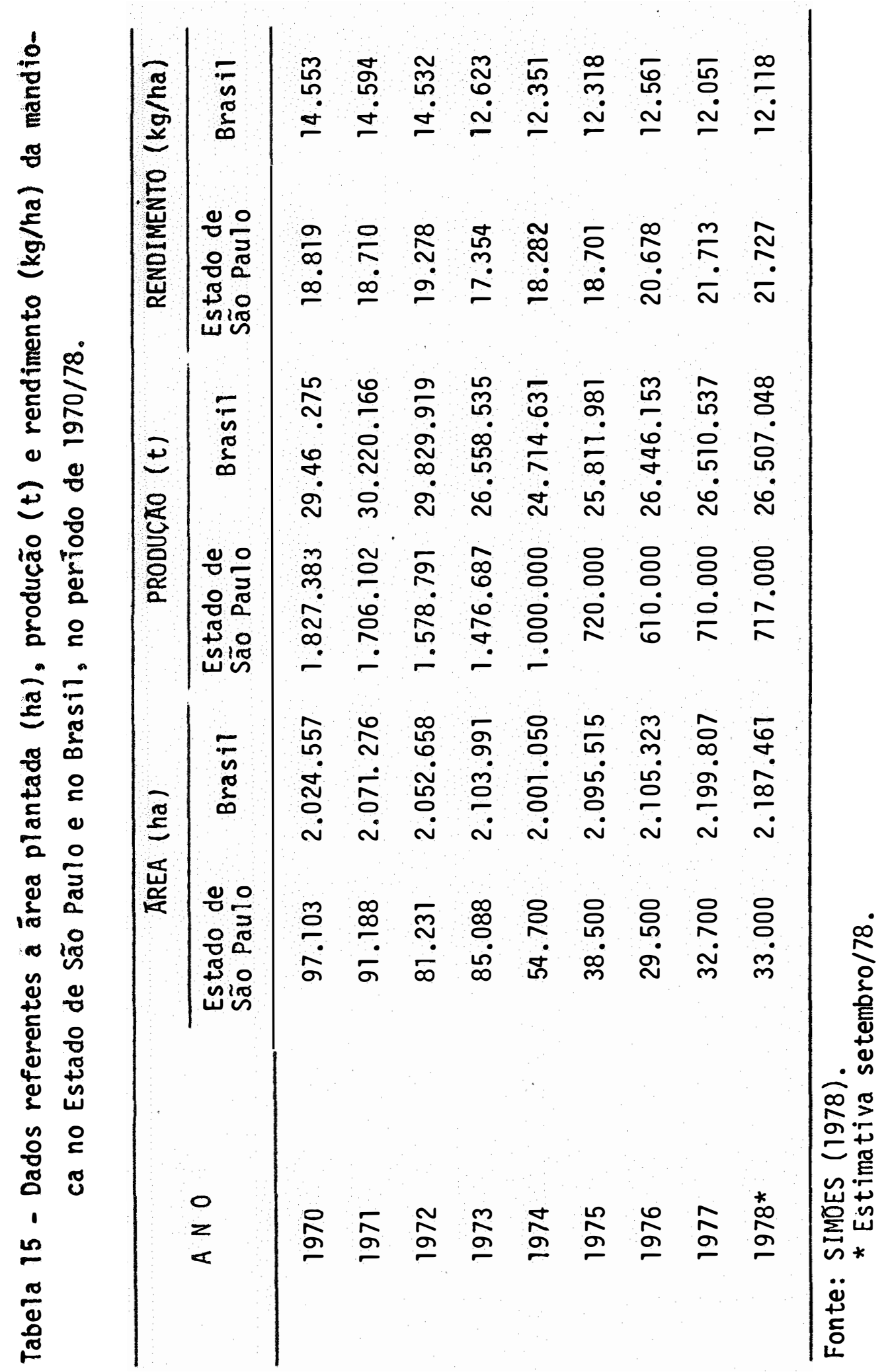


40.

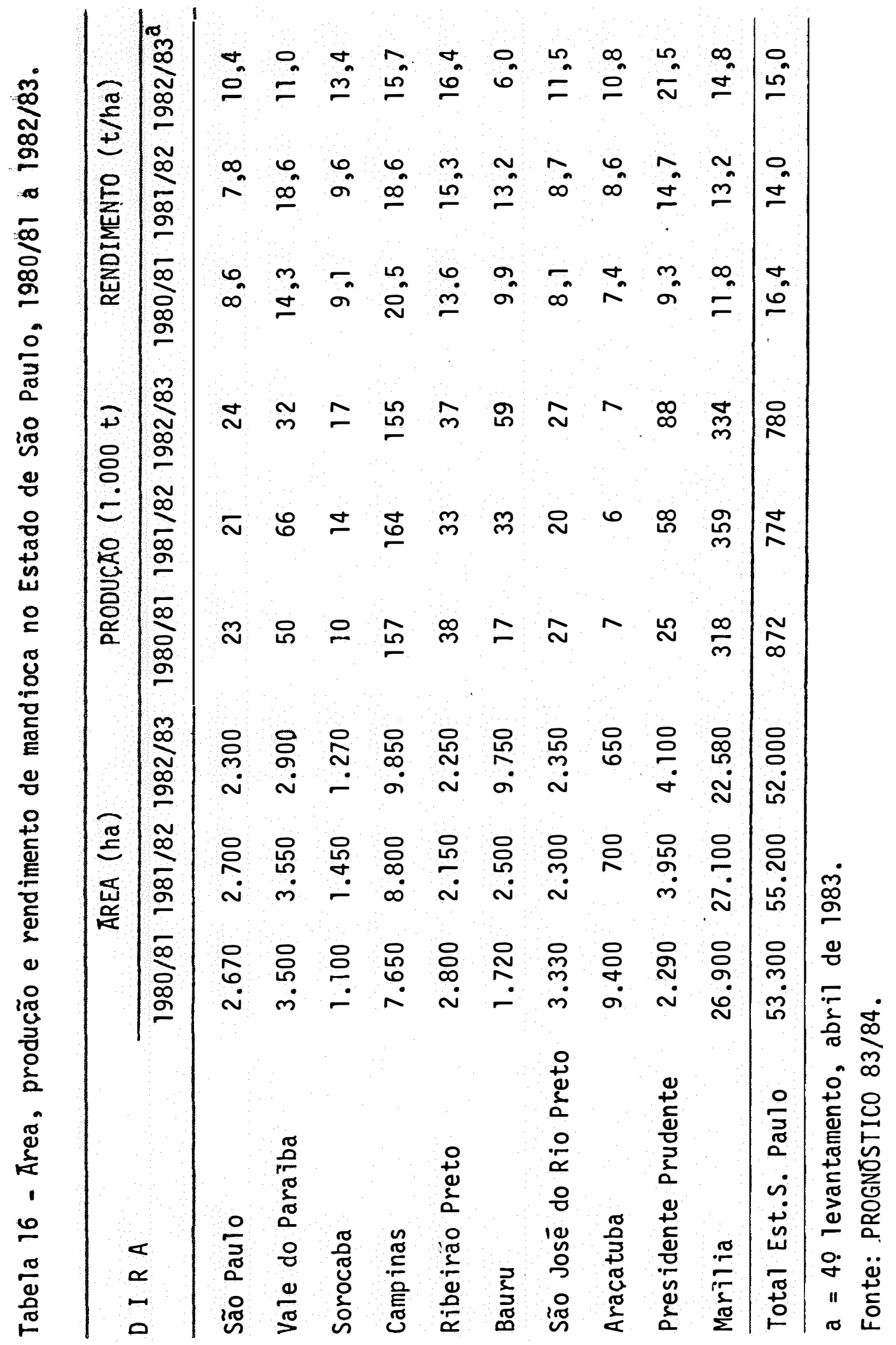


Neste caso, poderia ser utilizado um trator equipado para retirar as raizes do solo, ou mesmo uma māquina para cavar e levantar as raizes (MANER et alii, s/d). Entretanto, deve-se considerar que o uso de equipamentos pode onerar o custo final de produção desse alimento.

A raiz da mandioca fresca apresenta al to teor em umidade. Devido a esta caracteristica, nāo pode ser armazenada por mais de 3 ou 4 dias após a colheita, sem que ocorra a fermentação e, conseqüentemente, a dete-rioração das raizes. Com base nessas considerações, algu- mas das maneiras de se conservar a mandioca para poste-rior aproveitamento seria picar em fatias e expor ao sol por um periodo de 3 ou 4 dias para a completa desidrata-ção, para ser posteriormente moída e armazenada, ou manterial e ensilar ou, ainda, manter as raizes inteiras no solo e colher de acordo com a necessidade (MANER et alii,s/d). Após a desidrataçāo, se o conteūdo em umidade da mandioca for reduzido a $10 \%$ ou menos, este alimento po de ser armazenado por periodos superiores a um ano, sem apresentar grandes alterações no valor nutritivo. 
42.

\subsection{2 - Fatores tōxicos}

Do ponto de vista alimentar, a mandioca $\bar{e}$ representada por dois grupos: as mandiocas amargosas ou bravas e as doces ou mansas (NORMANHA e PEREIRA, 1950), de pendendo do maior ou menor teor de ācido cianídrico, o qual é considerado como fator tóxico.

A mandioca é considerada doce quando contēm menos que $50 \mathrm{mg}$ de ácido cianîdrico por quilograma do produto e amarga ou' tóxica quando a concentração em ácido cianidrico for superior a $100 \mathrm{mg}$ por quilograma do produto (BOLHUIS, 1954). Entretanto, JONES (1959) relata que as variedades doces apresentam uma concentracáo de ācido cia nidrico de $70 \mathrm{mg}$ por quilograma do produto, enquanto nas variedades amargás a concentração varia entre 200 a $300 \mathrm{mg}$ por quilograma do produto.

o ácido cianídrico livre não existe como tal, mas, sim, como componente de $\beta-g l i c o s i d e o s ~(1$ inamarina se e lotaustralina) existentes na mandioca. 0s glicosideos são formados através da combinação química do ácido cianidrico e glicose, os quais são liberados mediante a hidrōlise enzimātica (linamarinase). Nem os glicosideos, nem a enzima são tóxicos, se forem considerados isoladamente (couch, 1932, citado por MANER et alii, s/d). 
A hidrólise enzimática pode ser acelerada quando as raízes são imersas em água ou submetidas à ação do calor, sem exceder à temperatura de $75^{\circ} \mathrm{C}$, pois a enzima seria destruida (JONES, 1959). Entretanto, quando as raizes são lavadas e, posteriormente, secas ao sol ou em estufas, o ácido cianídrico é eliminado.

Quando a mandioca é fornecida aos animais, sem que o fator tóxico (o ācido cianîdrico) seja eliminado, pode causar problemas como respiraça acelerada e pro funda, pulsação acelerada, falta de estimulos e movimentos musculares espasmáticos. A maioria dos sintomas por intoxicação podem ser explicados através da afinidade entre o ácido cianỉdrico e íons metálicos, como o cobre e o ferro, que são considerados como componentes de metabōiitos de muita importāncia no organismo (hemoglobina, enzimas oxidativas, etc.), segundo OKE (1969).

o organismo possui a propriedade de eliminar certas quantidades de ácido cianídrico, que varia segundo a espécie animal, a condição física, o consumo de nutrientes e, provavelmente, a existēncia de outros fatores não identificados. Sabe-se que a enzima chamada rodanasa causa a reaça entre o ácido cianídrico e o tiosulfa to ou com o enxofre coloidal, produzindo o tiocianato que é um produto de desintoxicacão. A referida enzima encon- 
44.

tra-se distribuida em todos os tecidos do organismo, mas a maior concentração ocorre no fígado. A desintoxicação pode ocorrer em todas as partes do organismo, mas se dá principalmente no figado (MANER et alii, s/d).

Entretanto, o mecanismo da rodanasa não é a única forma de desintoxicação, através do qual o tiocia nato é produzido a partir do ácido cianídrico. E possível que o ácido $\beta$-mercaptopiruvico pode resultar em efeito tão rápido quanto o tiossulfato em caso de desintoxicacão. E provāvel que a vitamina $B_{12}$ também desempenhe um papel di reto ou indireto no caso de intoxicacão por ácido cianîdrico (MANER et alii, s/d).

2.2.3 - Métodos para reduzir os fatores tóxicos existentes na mandioca

Existem vārios métodos de processamento,com o objetivo de reduzir ou eliminar o fator tóxico (ácido cianidricol contido na raiz de mandioca.

Segundo MANER et alii ( $\mathrm{s} / \mathrm{d})$, a secagem da raiz de mandioca em forno com circulacão de ar forcada, a temperaturas moderadamente altas $\left(70\right.$ a $\left.80^{\circ} \mathrm{C}\right)$, a coccão em àgua e a desidratação através do sol são alguns dos méto-dos mais efetivos. 
A desidratacão da raiz da mandioca em forno com ausēncia de umidade permite a eliminação do ācido cianỉdrico livre e a destruição da enxima linamarase, a. qual é necessāria para hidrolisar o glicosīdeo e formar o ácido cianidrico. o calor seco quase não tem efeito na elimi nação do glicosídeo presente, e este se conserva na raiz. Considerando-se que após a ingestão da mandioca o ácido cianîdrico é liberado do glicosídeo através da hidrölise, pode-se considerar que pequenas quantidades do referido ácido poderão ser absorvidas pelo organismo animal quando a raiz da mandioca for desidratada através do calor seco (MANER et alii,s/d). Os mesmos autores relataram que,atra vés do processo de cocção em água, ocorre a destruição do ācido cianídrico livre, causando uma redução da quantidade total do glicosídeo, o qual é solūvel em ägua. Entretanto, se o cozimento for rāpido e continuo, durante curtos periodos de tempo, quantidades significativas de glicosideo podem permanecer na raiz, e quando esta raiz for ingerida, pode ocorrer a absorção do ácido cianỉdrico, da mesma forma explicada anteriormente (desidrataça da raiz da mandioca em forno).

Segundo CORREA (1947), o calor è o agente que permite a eliminação do ācido cianîdrico existente na raiz de mandioca. Cerca de $60 \%$ do total do referido ácido 
46.

se concentra na casca, e quando as raỉzes permaneceram ex postas ao sol durante 3 dias, cerca de $73 \%$ do total do àcido é eliminado. De acordo com MANER et a $z_{i} i(\mathrm{~s} / \mathrm{d})$, este processo se inicia atravēs da acão da enzima sobre o glicosídeo, o que causa a liberação do ācido cianídrico, atravēs de dissipação.

2.2.4 - Principais operaçoes na industrialização da raiz de mandioca e a obtenção dos seus subprodutos

A raiz de mandioca é colhida com 16 a 20 meses de estāgio vegetativo, devendo ser industrializada dentro de 36 horas, a contar da colheita, devido à ação de enzimas sobre substāncias tōxicas que a mandioca con-tēm, ocasionando no seu interior veias escuras ou azula-das, as quais levam á depreciação do produto.

\section{A. Operacões}

Segundo os estudos realizados por LEME JUNIOR (1965), a industrializacão da raiz da mandioca pode ser feita da seguinte maneira:

a) Lavagem e descascamento: essa operacão é feita atravēs de um aparelho denominado lavador-descascador, onde as raizes de mandioca sao lavadas e descascadas, opera 
ção essa em que saem as cascas, película parda e casca branca. Nessa operaço são separadas da raiz as impurezas como pedras e terra.

b) Ralaçäo: é feita para produção da farinha de mesa.

c) Corte das raizzes: é feito para produçăo de farinha de raspas.

d) Prensagem e expremedura: nesta fase as raĩzes se encontram raladas e cortadas. A massa obtida apresenta grande quantidade de àgua, tornando-se necessārio eliminar a umidade para facilitar a industrialização.

e) Secagem: é feita em secadores a ar quente ou a va por, ou em torradores, como é o caso da farinha de mesa.

\section{B. Produtos obtidos}

De acordo com PEIXOTO (1963) e LEME JUNIOR (1965), apōs o processamento da raiz de mandioca obtēm-se os seguintes produtos e subprodutos, respectivamente: 0 amido e farelo de amido ou de bagaco; farinha de mesa e fa relo de farinha de mesa; farinha de raspas e farelo de farinha de raspas. o farelo de varredura e do lavador é um subproduto obtido através do processamento para a obtencão do amido, farinha de mesa e de raspas, onde todo o ma terial perdido no chão é juntado ao do resíduo do lavador 
após a secagem e moagem deste. 0 farelo de varredura é,ge ralmente, um subproduto escuro, devido à presença de terra.

\subsection{5 - Composição bromatológica da mandioca}

A raiz de mandioca fresca contém, em média, $65 \%$ de umidade e $35 \%$ de matéria seca. Na Tabela 17 pode ser observada a composicão bromatológica de diversas varieda des de mandioca (MANER et alii, s/d).

Tabela 17 - Composição tromatológïca de 15 variedàdes colombianas de mand ioca . !

\begin{tabular}{|c|c|c|c|c|c|c|}
\hline VARIEDADES & $\begin{array}{l}\text { Umi- } \\
\text { dade } \\
(\%)\end{array}$ & $\begin{array}{c}\text { Prote } \bar{i} \\
\text { na bru } \\
\text { ta } \\
(\%)\end{array}$ & $\begin{array}{c}\text { Fibra } \\
\text { bruta } \\
(\%)\end{array}$ & $\begin{array}{l}\text { Extrato } \\
\text { etéreo } \\
(\%)\end{array}$ & $\begin{array}{c}\text { Matéria } \\
\text { mineral } \\
(\%)\end{array}$ & $\begin{array}{c}\text { Extrati- } \\
\text { vos não } \\
\text { nitroge- } \\
\text { nados } \\
(\%)\end{array}$ \\
\hline $\begin{array}{l}\text { Lhanera } \\
\text { Santa Catalina } \\
\text { H-50 } \\
\text { Tolima } \\
\text { C.M.C.-50 } \\
\text { I-35 Brava } \\
\text { Blanca - no } 2 \\
\text { C.M.C.-1 } \\
\text { C.M.C.-3 } \\
\text { C.M.C. -4 } \\
6 \text { meses comum } \\
\text { Amarilla } \\
\text { Tempratina } \\
\text { La Respetada } \\
\text { Barbolita }\end{array}$ & $\begin{array}{l}67,90 \\
64,76 \\
66,71 \\
61,85 \\
60,61 \\
61,21 \\
62,70 \\
62,18 \\
61,50 \\
67,59 \\
65,35 \\
64,16 \\
77,32 \\
62,84 \\
68,81\end{array}$ & $\begin{array}{l}2,33 \\
2,14 \\
0,56 \\
0,40 \\
1,55 \\
2,06 \\
1,25 \\
1,97 \\
1,70 \\
1,71 \\
0,67 \\
0,59 \\
0,63 \\
1,03 \\
0,18\end{array}$ & $\begin{array}{l}0,97 \\
1,16 \\
2,03 \\
1,35 \\
1,09 \\
1,18 \\
1,02 \\
2,16 \\
1,77 \\
3,46 \\
1,00 \\
1,64 \\
1,07 \\
1,02 \\
0,77\end{array}$ & $\begin{array}{l}0,18 \\
0,24 \\
0,35 \\
0,25 \\
0,36 \\
0,31 \\
0,29 \\
0,30 \\
0,24 \\
0,35 \\
0,43 \\
0,33 \\
0,24 \\
0,22 \\
0,25\end{array}$ & $\begin{array}{l}0,95 \\
1,00 \\
1,71 \\
1,54 \\
1,40 \\
1,03 \\
1,36 \\
2,49 \\
1,38 \\
1,59 \\
1,29 \\
1,81 \\
1,58 \\
1,26 \\
0,94\end{array}$ & $\begin{array}{l}27,67 \\
30,71 \\
28,58 \\
34,61 \\
35,07 \\
34,14 \\
33,36 \\
30,89 \\
33,34 \\
25,27 \\
31,35 \\
35,90 \\
19,17 \\
33,49 \\
29,05\end{array}$ \\
\hline
\end{tabular}

Fonte: MANER et alii $(\mathrm{s} / \mathrm{d})$.

I/ Laboratōrio de Nutrição - Centro Internacional de Agricultura (I. C.A.), Colômbia. 
Considerando-se os dados da Tabela 17, os autores ressaltaram que $31 \%$ da raiz fresca é constituida por extrativos não nitrogenados, composto principalmente por amido e açūcares. A fração de extrativo não nitrogena do é constituída aproximadamente por $80 \%$ de amido e $20 \%$ de açūcares e amidas (VOGT, 1966), sucrosol em quantidades variāveis, as quais atingem, em até $5 \%$ em algumas variedades, segundo Brandtlecht (1953), citado por MANER et $\operatorname{arii}(\mathrm{s} / \mathrm{d})$.

A unidade básica da molécula do amido é a d-glicose. Os componentes principais do amido são a amilo se, de estrutura reta e, a amilopectina, cuja estrutura estā ramificada em várias cadeias. Segundo KERR (1950) e JOHNSON e RAYMOND (1965), o amido da mandioca contém apró ximadamente $20 \%$ de amilose e $70 \%$ de amilopectina. Com ba se no conteúdo em amilose, pode-se considerar que seja es ta a causa da propriedade viscosa, caracteristica do amido da mandioca.

Considerando-se ainda a Tabela 17 , pode ser observado que a mandioca apresenta porcentagens baixas de fibra bruta $(1,45 \%)$ e porcentagem quase desprezivel de ex trato etéreo $(0,20 \%)$. 0 conteúdo em matéria mineral é de aproximadamente $1,5 \%$. os teores em cālcio, fósforo, sódio, 
50 .

magnēsio e potássio, observados em anālises realizadas por MANER et $a Z_{i} i \cdot(s / d)$ são apresentados na Tabela 18.

Tabela 18 - Conteúdo de minerais de 10 variedades colonbianas de mandioca I'.

\begin{tabular}{lccccc}
\hline VARIEDADES & $\begin{array}{c}\text { Cálcio } \\
(\%)\end{array}$ & $\begin{array}{c}\text { Fósforo } \\
(\%)\end{array}$ & $\begin{array}{c}\text { Sōdio } \\
(\%)\end{array}$ & $\begin{array}{c}\text { Potāssio } \\
(\%)\end{array}$ & $\begin{array}{c}\text { Magnésio } \\
(\%)\end{array}$ \\
\hline Lhanera & 0,06 & 0,17 & 0,05 & 0,92 & 0,40 \\
Sta. Catalina & 0,09 & 0,15 & 0,04 & 0,66 & 0,40 \\
H - 50 & 0,14 & 0,23 & 0,04 & 1,30 & 0,30 \\
Tolitma & 0,06 & 0,20 & 0,04 & 1,07 & 0,22 \\
C.M.C.-50 & 0,06 & 0,15 & 0,07 & 0,80 & 0,22 \\
I- 35 & 0,05 & 0,16 & 0,07 & 0,70 & 0,34 \\
Blanca no 2 & 0,07 & 0,17 & 0,04 & 1,05 & 0,31 \\
C.M.C. - 1 & 0,28 & 0,10 & 0,09 & 0,84 & 0,45 \\
C.M.C. - 3 & 0,13 & 0,11 & 0,08 & 0,72 & 0,35 \\
C.M.C. - 4 & 0,21 & 0,19 & 0,05 & 0,58 & 0,70 \\
\hline MEDIA & 0,12 & 0,16 & 0,06 & 0,86 & 0,37 \\
\hline
\end{tabular}

Fonte: MANER et alii ( $\mathrm{s} / \mathrm{d})$.

1/ Amostra de mandioca seca ao ar com 10\% de umidade, aproxi-madamente.

A maioria das variedades de mandioca produ zidas atualmente apresentam pequenas quantidades de nitro gênio. O conteúdo em proteína $(N \times 6,25)$ na maioria das variedades de mandiocas analisadas não excede a $3,0 \%$, qua $\underline{n}$ do expressa com base na matēria seca ao ar (10\% de umidade), se gundo MANER et alii $(s / d)$. Entretanto, conteúdos mais ele 
vados em proteína bruta podem ser observados em algumas variedades da coleção mundial de Manihot carthagenensis, as quais apresentam cerca de $15,4 \%$ de proteina bruta na matēria seca (LOPEZ e HERRERA, 1970).

Os estudos realizados por Maner e Daniels (1970), citados por MANER et alii (s/d), mostraram que a totalidade do nitrogēnio na mandioca não se encontra na forma de proteina. Os dados apresentados na Tabela 19 mos tram o alto conteūdo em nitrogénio, observados nas amostras da variedade "Lhanera", colhidas aproximadamente a cada duas semanas, durante o período de sete meses. 0 total de nitrogénio na raiz inteira variou de 0,74 a $1,02 \%$ $(4,63$ a $6,35 \%$ de proteĩna total), e também que esse conteūdo em nitrogēnio é maior no cortex quando comparado com a raiz inteira e polpa.

Os estudos realizados por Calderon (1971), citados por MANER et $a$ lii (s/d), com relação à fração $n i-$ trogenada em 15 variedades de mandioca, permitiram constatar que o conteūdo total de nitratos, nitritos e àcido cianídrico representam aproximadamente $1,0 \%$ do $n i-$ trogënio total. Baseando nesses mesmos estudos, o citado autor concluiu que os àcidos glutāmico e aspārtico podem estar presentes na raiz da mandioca, na forma de aminoācidos $1 \underline{i}$ 
vres e representam uma porcão do nitrogēnio nao protéico, os qquais não precipitam com óácido tricloroacētico.

Algumas pesquisas foram desenvolvidas por SREERAMANURTHY (1945), as quais mostraram que os aminoácidos essenciais existentes na mandioca estão presentes na proteina total (1,33\% na amostra) e são representados por $7,74 \%$ de arginina, $15 \%$ de histidina, $5,33 \%$ de isoleucina, $5,56 \%$ de 1 eucina, $6,23 \%$ de 1 isina, $0,60 \%$ de metionina, $3,45 \%$ de fenilalanina, $3,83 \%$ de treonina, $0,53 \%$ de triptofano e 4,51 de valina.

Close et alii (1953), citados por MANER et alii $(\mathrm{s} / \mathrm{d})$, constátaram que a proteina da farinha de man dioca apresenta os seguintes'aminoácidos: $4,4 \%$ de ácido aspártico, 2,1\% de treonina, $1,9 \%$ de serina, $12,7 \%$ de áci do glutāmico, $1,6 \%$ de prolina, $2,4 \%$ de glicina, $4,6 \%$ de alanina, 2,6\% de valina, $0,6 \%$ de cistina, $1,0 \%$ de metion $\underline{i}$ na, 2,0\% de isoleucina, $219 \%$ de leucina, $1,6 \%$ de tirosina, $2,3 \%$ de fenilalanina, $3,5 \%$ de 1 isina, $0,5 \%$ de triptofano, $10,4 \%$ de ornitina, $1,2 \%$ de histidina e $3,7 \%$ de arginina. 
53.

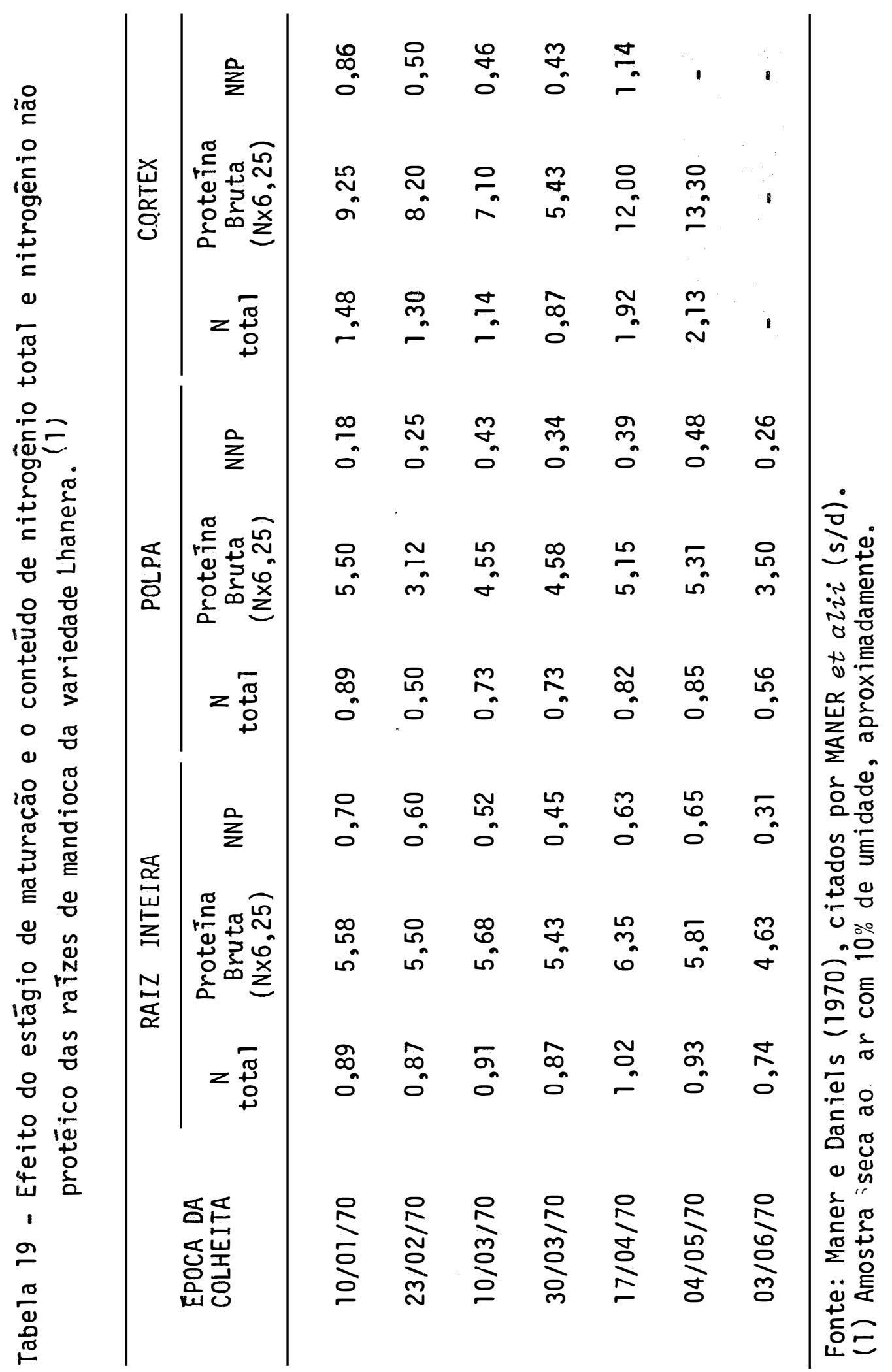


54.

\subsection{6 - Utilização da mandioca na alimentação dos suínos}

\subsubsection{1 - Desempenho}

Desde o inīcio do sēculo tem-se mencionado em literatura a realização de pesquisas, com o objetivo de se determinar o valor nutritivo da mandioca como fonte de energia na alimentacão dos suínos (HENKE, 1923; MONDONEDO e BAYAN, 1927; ALBA, 1937; ÁSICO, 1941; PEIXOTO, 1965 e SHIMADA, et alii 1970).

Um resumo de trabalhos realizados por $\bar{v}$ rios pesquisadores, no período de 1927 a 1941 , citados por MANER et alii (s/d) è apresentado na Tabela 20.

Tabela 20 - Resumo de trabalhos realizados no período de 1927 a 1941 , utilizando-se a mandioca como alimento para suínos.

\begin{tabular}{ccccccc}
\hline $\begin{array}{c}\text { NIVEL DE } \\
\begin{array}{c}\text { MANDIOCA } \\
(\%)\end{array}\end{array}$ & $\begin{array}{c}\text { PESO } \\
\text { MEDIO } \\
(\mathrm{kg})\end{array}$ & $\begin{array}{c}\text { GANHO DE } \\
\text { PESO DIA } \\
\text { RIO }(\mathrm{kg})\end{array}$ & $\begin{array}{c}\text { CONVERSAO } \\
\text { ALIMENTAR }\end{array}$ & AUTOR & ANO \\
\hline 20 & $11-26$ & 0,206 & 2,65 & MANDONEDO e BAYAN & 1927 \\
20 & $28-40$ & 0,175 & 2,52 & MANDONEDO e BAYAN & 1927 \\
30 & $39-62$ & 0,325 & 6,46 & MANDONEDO e BAYAN & 1927 \\
20 & $32-60$ & 0,396 & 4,76 & MANDONEDO & 1928 \\
$24-40$ & $35-82$ & 0,609 & 4,03 & HOODMAN & 1931 \\
15 & $12-30$ & 0,250 & 3,51 & ASICO & 1941 \\
20 & $30-50$ & 0,280 & 6,35 & ASICO & 1941 \\
25 & $50-70$ & 0,300 & 6,86 & ASICO & 1941 \\
$15-25$ & $12-70$ & 0,270 & 5,68 & ASICO & & 1941 \\
\hline
\end{tabular}

Fonte: MANNER et $a z_{i} i$ (s/d). 
Estudando a Tabela 20 , MANER et alii ( $\mathrm{s} / \mathrm{d}$ ) observaram que a mandioca pode fazer parte da alimentacão dos suỉnos até o nīvel de $40 \%$. Entretanto, vários trabaIhos mostraram que nîveis menores que $40 \%$ podem afetar 0 desempenho dos animais, afetando o ganho de peso.

TORRES (1958) realizou um experimento com suinos em fases de crescimento e terminação, utilizando a raspa de mandioca e o farelinho de trigo desintegrado. Os tratamentos foram: $T_{1}=70 \mathrm{~kg}$ de ração basal (milho desin tegrado + farelo de babaçu + farelo de algodão + soja mo $\mathrm{da}+$ tancage $)+30 \mathrm{~kg}$ de farelinho moido de trigo; $\mathrm{T}_{2}=70$ $\mathrm{kg}$ de ração basal + $15 \mathrm{~kg}$ de farelinho de trigo remoído + $+15 \mathrm{~kg}$ de raspa de mandioca e $\mathrm{T}_{3}=70 \mathrm{Kg}$ de ração basa $+30 \mathrm{Kg}$ de raspa de mandioca. Os resultados obtidos pelo autor, referentes ao desempenho dos suínos, são mostrados na Tabela 21. 0 autor concluiu que, apesar das diferencas entre os tratamentos não terem sido significativas, os resultados obtidos indicaram uma tendencia de inferioridade do tratamento em que foi feita a substituição total do farelo de trigo por raspa de mandioca. 
Tabela 21 - Desempenho dos suĩnos, durante a fase experimental.

\begin{tabular}{lrrr}
\hline \multirow{2}{*}{ INDICES ESTUDADOS } & \multicolumn{3}{c}{ TRATAMENTOS } \\
\cline { 2 - 4 } & \multicolumn{1}{c}{1} & \multicolumn{1}{c}{2} & 3 \\
\hline Peso mëdio inicial $(\mathrm{kg})$ & 14,200 & 13,500 & 15,750 \\
Peso mëdio final $(\mathrm{kg})$ & 106,050 & 112,700 & 103,350 \\
Ganho médio total $(\mathrm{kg})$ & 91,850 & 99,350 & 75,550 \\
Ganho médio diärio $(\mathrm{kg})$ & 0,547 & 0,591 & 0,449 \\
Consumo mëdio total/animal $(\mathrm{kg})$ & 2,552 & 2,635 & 2,499 \\
Conversão al imentar & 4,665 & 4,459 & 5,143 \\
\hline
\end{tabular}

Fonte: TORRES (1958).

TORRES (1956/1959) conduziu outro experimento com suĩnos, testando a utilização da raspa de mandioca. A ração basal era constituĩda de farelinho de trigo $(15 \mathrm{~kg})$, remoído de trigo $(15 \mathrm{~kg}$ ), farelo de babaçu ( 5 $\mathrm{kg}$ ), farelo de algodão $(5 \mathrm{~kg})$, soja moĩda $(4 \mathrm{~kg})$, tancage $(4 \mathrm{~kg})$, mistura mineral $(2 \mathrm{~kg})$. Os tratamentos foram: $T_{1}=$ ração basal $(50 \mathrm{~kg})+$ milho desintegrado $(50 \mathrm{~kg}) ; \mathrm{T}_{2}=$ ra cão basal $(50 \mathrm{~kg})+$ milho desintegrado $(35 \mathrm{~kg})+$ raspa moîda $(15 \mathrm{~kg})$; e $\mathrm{T}_{3}=$ racao basal $(50 \mathrm{~kg})$ + milho desinte grado $(20 \mathrm{~kg})+$ raspa moída $(30 \mathrm{~kg})$. Ao final do experimento, foram obtidos os dados de desempenho dos suínos,os quais são apresentados na Tabela 22. 0 autor concluiu que os dois níveis de substituicăo, 15 e $30 \%$ de milho desinte grado por raspa moîda de mandioca diferiram significativa 
mente em seus efeitos sobre os ganhos de peso. A racão sem raspa de mandioca teve efeito intermediārio entre aque las duas. Para consumo de racão, observou que houve um consumo de $12 \%$ a mais para a ração com nîvel de $15 \%$ de raspa de mandioca e $13 \%$ a menos para a ração com $30 \%$ de raspa de mandioca em relação ao tratamento testemunha,não sendo, entretanto, observadas diferencas estatisticamente significativas. Quanto à conversão alimentar, os dados ob tidos nos 3 tratamentos foram mu ito prōximos, não diferin do estatisticamente:

Tabela 22 - Desempenho dos suĩnos, durante 140 dias de experimento.

\begin{tabular}{|c|c|c|c|}
\hline \multirow{2}{*}{ INDICES CONTROLADOS } & \multicolumn{3}{|c|}{ TRATAMENTOS } \\
\hline & 1 & 2 & 3 \\
\hline Peso mëdio inicial $(\mathrm{kg})$ & 18,333 & 18,767 & 18,400 \\
\hline Peso médio final $(\mathrm{kg})$ & 93,033 & 105,000 & 86,300 \\
\hline Ganho médio total $(\mathrm{kg})$ & 74,700 & 86,233 & 67,900 \\
\hline Ganho médio diārio $(\mathrm{kg})$ & 0,533 & 0,616 & 0,485 \\
\hline Consumo médio total $(\mathrm{kg})$ * & 395,100 & 444,000 & 341,800 \\
\hline Consumo médio diärio $(\mathrm{kg})$ & 2,822 & 3,172 & 2,441 \\
\hline Converșão al imentar & 5,289 & 5,149 & 5,034 \\
\hline
\end{tabular}

Fonte: TORRES (1956/1959). * Consumo médio total/animal. 
MEJIA (1960), testou niveis de 20 e $40 \%$ de farinha de mandioca seca ao sol, em substituicão ao mi lho na alimentação de suinos, nas fases de crescimento e terminação. Através dos resultados obtidos, o autor pōde observar que os animais que receberam racão com $40 \%$ de fa rinha de mandioca apresentaram ganho de peso superior $(0,607 \mathrm{~g} / \mathrm{dia})$ quando comparados com a raça sem farinha $(0,527 / d i a)$. Quando considerou a conversão al imentar, verificou que os animais, recebendo $40 \%$ de raspa de mandio$\mathrm{ca}$, consumiram menor quantidade de alimento por $\mathrm{kg}$ por ganho. de peso.

PEIXOTO (1965) conduziu um experimento com suínos, com peso médio inicial em torno de $20 \mathrm{~kg}$, sendo testados os seguintes tratamentos: $T_{1}=$ farinha de mandio ca + suplemento protéico I (22\% de farinha de carne $+25 \%$ de farelo de soja $+20 \%$ de farelo de trigo $+2,5 \%$ de mine ral + 0,5\% de óleo de bacalhau); $T_{2}=$ farinha de mandioca + suplemento protéico $\underline{2}$ (30\% de farinha de carne $+67 \%$ de farelo de soja $+3 \%$ de mineral); $T_{3}=$ milho + suplemento protéico I; e $T_{4}=$ milho + suplemento protéico 2. 0 milho e a farinha de mandioca foram fornecidos à vontade e os suplementos protéicos duas vezes ao dia. Ao final do expe rimento o autor constatou que os animais alimentados com a farinha de mandioca atingiram o peso de abate $(93,16 \mathrm{~kg}$ em 
59 .

105 dias) mais lentamente do que os alimentados com milho $(99,55 \mathrm{~kg}$ em 77 dias $)$.

VELLOSO et alii $(1965 / 1966)$ testaram a in clusão do farelo de mandioca em nîveis de 0,$0 ; 22,0 ; 45,0$ e $62,0 \%$, em substituição ao milho em rações para suỉnos com peso inicial de $54 \mathrm{~kg}$. Os ganhos de pesos médios foram: $73,70 \mathrm{~kg}$ para ração sem farelo; $64,10 \mathrm{~kg}$ para ração com $22,0 \%$ de farelo; $60,60 \mathrm{~kg}$ para ração com $45,0 \%$ de farelo de $46,40 \mathrm{~kg}$ para ração com $62 \%$ de farelo de mandioca em substituicão a milho: Os autores observaram que o desempenho dos animais foi afetado com o aumento do nivel de farelo de mandioca em substituição ao milho. A eficiência alimentar ligeiramente inferior, quando comparando a racão contendo farelo de mandioca e raça sem farelo de mandioca, seria explicável, segundo ALBA (1951), como decorrente do al to conteúdo de amido existente no farelo de mandioca, ou, de acordo com 01 son et alii (1969), citados por HERNANDEZ e BRANBILLA (1969), pelo fato de que a energia metabolizável desse amido é inferior à do amido do milho, contrariando TRINDADE et alii (1974), os quais mencionaram que a ener- 
60.

gia metabolizável da mandioca e do milho sáo semelhantes. MAUST et alii (1969) substituiram o milho por farinha de mandioca, em värios niveis, em racões de suinos em fase de terminação. Os autores observaram que, com o nivel de $36 \%$ de substituicão, os animais tiveram o consumo afetado e também o aparecimento de paraqueratose. $\mathrm{Na}$ tentativa de evitar o problema surgido no experimento citado anteriormente, MAUST et alii(1972) utilizaram leitões em fase de crescimento, suplementando com zinco uma dieta constituida de farelos de mandioca e arroz, como fonte principal de energia, comparada com outra à base de milho. Quanto ao zinco, apesar dos niveis serem semelhantes nas duas dietas ( 40 e 48 ppm), os leitões submetidos à dieta baseada em farelo de mandioca e farelo de arroz ainda apre sentaram deficiencias, as quais foram corrigidas com nīvel de $52 \mathrm{ppm}$ de zinco $\left(\mathrm{Zn}_{\mathrm{CO}_{3}}\right)$ a partir do 330 dia de vi da dos animais. Esta suplementação de zinco levou a um melhor ganho de peso, sugerindo que a mistura mandioca mais arroz leva a uma diminuicão da disponibilidade bioló gica do zinco. Observaram também que a dieta à base de mi tho levou a um melhor desempenho dos suinos, quando compa rada com as demais.

A mandioca tem sido comparada com muitas fontes de energia. Desta forma, MESA et alii (1970) reali 
zaram pesquisas com milho, açúcar refinado, açūcar não re finado, melaco de cana, mandioca seca e banana seca na al imentação dos suinos. As fontes energéticas substituíram o milho cuja proporcão variou juntamente com a do suplemento protéico para que todas as dietas tivessem $16 \%$ de proteina bruta. Os autores concluíram que, com exceção da dieta à base de banana seca, que pareceu conter o maisba $\underline{i}$ xo nível de energia utilizável, todas as outras fontes de energia se mostraram satisfatōrias, embora os melhores re sultados de ganho de peso tivessem sido obtidos comos an mais alimentados com dietas à base de acúcar (refinado ou não refinado).

MANER èt alii (1970) realizaram uma série de experimentos utilizando a mandioca juntamente com dife rentes fontes protéicas, tais como farelo de algodão, farelo de soja, farinha de carne, farinha de sangue associa da à farinha de carne e farinha de peixe associada com fa relo de algodão. Em todas as dietas testadas, os animais apresentaram desempenho semelhante, exceção feita à dieta à base de farelo de algodão que, pelo conteúdo em lisina, resultou em um desempenho significativamente inferior.

SHIMADA et alii (1970) utilizaram 0, 22, 44 e $66 \%$ de mandioca seca ao sol, em substituicão ao milho, na alimen tação de suínos com peso entre 30 e $90 \mathrm{~kg}$. Apesar do autor ressaltar que utilizou número inadequado de animais 
para se fazer uma anāitise estatistica, os resultados do experimento indicaram que $44 \%$ de farinha de mandioca pode substituir o milho, sem afetar o desempenho dos animais. Entretanto, o nivel de $66 \%$ levou a um menor ganho de peso e a uma pior conversāo alimentar.

Uma pesquisa foi realizada por CHICCO et alii (1972), utilizando 24 suinos com peso médio inicial de $43 \mathrm{~kg}$, os quais foram alimentados com dietas contendo $60 \%$ de milho (ração basal), sendo o milho substituído em 25, 50 e $100 \%$ por farinha de mandioca. Ao término do expe rimento, quando os animais atingiram em média $82,50 \mathrm{~kg}$ de peso vivo, os autores observaram ganho de peso médio de $804 \mathrm{~g} / \mathrm{dia}$ e conversão alimentar de 3,45 , nāo tendo sido observadas diferencas estatísticas entre os tratamentos.

Pesquisas tentando verificar o efeito da substituicão de cereais por farinha de mandioca, em diferentes formas (farelada e peletizada) na proporcāo de 40 a $75 \%$ da ração basal, foram realizadas por MULLER et a $i$ i (1974), os quais descreveram não haver efeito prejudicial em nenhum dos níveis de substituicão. Os autores constata ram uma preferēncia dos animais pelas raçoses com mandioca e na forma peletizada e que o desempenho dos animais não foi afetado, qualquer que fosse a proporcão de farinha de man dioca fornecida, desde que devidamente equilibrada com re 
63.

1 ação a todos os fatores 1 imitantes. Esses resultados foram confirmados por PEIXOTO et alii (1973), os quais forneceram aos suínos dieta contendo $50 \%$ de mandioca seca mo da ou na forma peletada.

Vārias pesquisas realizadas por SANTANA et alii (1978) levaram os autores a concluir que os subprodu tos da raiz da mandioca podem substituir o milho em racões de suínos, desde que os niveis de proteína e energia sejam os adequados para as diversas fases da vida dos an $\underline{i}$ mais, além de se adicionar DL metionina quando o farelo de soja for empregado como fonte protéica. Em condicões semelhantes, ZOBY (1967) chegou às mesmas conclusões.

\subsubsection{2 - Características de carcaça}

As pesquisas ainda são escassas no que diz respeito à utilização da mandioca ou de seus subprodutos na alimentação de suínos e seus efeitos nas características de carcaca. 
PEIXOTO (1965) testou a farinha de mandioca como ingrediente de rações de suĩnos, e seus efeitos nas caracteristicas de carcaca, sendo que os resultados obtidos são apresentados na Tabela 23. Considerando os da dos obtidos,observaram que a racão com farinha de mandioca proporcionou carcacas mais compridas, porem com maior espessura de toicinho e menos carne. 0 rendimento das carca cas dos suinos alimentados com farinha de mandioca foi su perior em $3,8 \%$, apresentando também toicinho mais firme, quando comparado com a ração à base de milho.

Tabela 23 - Dados referentes a características de carcaça, dos suínos al imentados com milho e farinha de mandioca.

INDICES CONTROLADOS

Peso vivo $(\mathrm{kg})$

Carcaça quente $(\mathrm{kg})$

Carcaça fria $(\mathrm{kg})$

Rendimento da carcaça (\%)

Comprimento da carcaça $(\mathrm{cm})$

Area de olho do lombo $\left(\mathrm{cm}^{2}\right)$

Espessura do toucinho $(\mathrm{cm})$
Farinha de Mandioca

101,20

83,00

81,30

80,20

76,20

22,80

0,52
Mitho 99,50 77,70 76,10 76,40 73,70 25,50 0,46

Fonte: PEIXOTO (1965). 
65.

CHICCO et alii (1972) testaram as seguintes proporcões de milho: farinha de mandioca: 60:0; 40:20; 20:40 e 0:60, na alimentacão de suínos, e seus efeitos nas características de carcaca. Ao término do experimento, os autores obtiveram os resultados, os quais são apresentados na Tabela 24. Os autores não observaram diferencas es tatísticas entre os tratamentos. Entretanto, ressaltaram a ocorréncia em aumentar a espessura do toicinho, com 0 aumento da proporcão de farinha de mandioca na racão.

Tabela 24 - Influência do mitho e da farinha de mandioca sobre o desempenho de suĩnos e a qualidade de carcaça.

\begin{tabular}{|c|c|c|c|c|}
\hline \multirow{2}{*}{ INDICES ESTUDADOS } & \multicolumn{4}{|c|}{ Milho:farinha de mandioca } \\
\hline & $60: 0$ & $40: 20$ & $20: 40$ & $0: 60$ \\
\hline Peso vivo $(\mathrm{kg})$ & 82,40 & 81,80 & 84,90 & 83,00 \\
\hline Comprimento carcaça $(\mathrm{cm})$ & 74,00 & 82,10 & 73,00 & 74,00 \\
\hline Espessura do toucinho & 3,10 & 3,40 & 3,30 & 3,90 \\
\hline
\end{tabular}

Fonte: CHICCO et alii (1972).

PEIXOTO e FARIAS (1974), baseados nas considerações feitas por PEIXOTO (1965) e PEIXOTO e ISLABAOO (1969), em que um dos fatores limitantes no que se refere à inclusão da farinha de mandioca em racões de suínos está no seu menor consumo, provavelmente devido a sua textú 
66.

ra pulverulenta, tentaram contornar essa situacão com a prensagem da ração com alto teor de mandioca (59\%) e sem milho, comparando com a mesma ração, porém farelada, e seus efeitos nas carcacas dos animais. Os resultados são mostrados na Tabela 25. Os autores concluiram que a prensagem não alterou as características de carcaça.

Tabela 25 - Características das carcaças de suĩnos al imentados com ra ção contendo al to teor de mandioca ( $50 \%$ ) na forma farelada e prensada.

\begin{tabular}{lcc}
\hline INDICES CONTROLADOS & Farelada & Prensada \\
\hline Peso médio ao abate $(\mathrm{kg})$ & 90,00 & 90,10 \\
Peso da carcaça fria $(\mathrm{kg})$ & 66,80 & 66,80 \\
Comprimento da carcaça (cm) & 91,60 & 92,90 \\
Rendimento da carcaça (\%) & 74,20 & 74,10 \\
Area de olho do lombo ( $\left.\mathrm{cm}^{2}\right)$ & 33,10 & 33,50 \\
Espessura do toucinho (cm) & 3,16 & 3,25 \\
Porcentagem de pernil & 29,60 & 29,60 \\
Relação carne:gordura & 0,80 & 0,75 \\
\hline
\end{tabular}

Fonte: PEIXOTO e FARIAS (1974).

PEIXOTO e FARIAS (1975) verificaram o efe $\underline{i}$ to da adição de óleo de soja a uma ração contendo $55 \%$ de farinha de mandioca em fase de crescimento-terminação (20 aos $95 \mathrm{~kg}$ de peso vivo). Os tratamentos foram: $T_{1}=$ sem óleo e $\mathrm{T}_{2}=\operatorname{com} 3 \%$ de óleo de soja. Para as caracteristi- 
cas de carcaça não foram observadas diferenças significativas e os resultados foram: espessura de toucinho $=3,1$ e 3,2 cm; área de olho do lombo $=31,5 \mathrm{e} 32,5 \mathrm{~cm}^{2}$; área de gordura $=23,4$ e $26,1 \mathrm{~cm}^{2}$; relação gordura:carne $=0,76$ e 0,79 ; peso do pernil $=9,7$ e $9,7 \mathrm{~kg}$; porcentagem de per nil na carcaça fria $=64,8$ e 65,8 ; rendimento da carca $c a=74,8$ e $76,1 \%$, respectivamente, para os tratamentos $\mathrm{T}_{1}$ e $\mathrm{T}_{2}$. 
68.

3. MATERIAL E METODOS

0 presente estudo foi conduzido nas instalações do Setor de Suinocultura do Departamento de Produção Animal da Faculdade de Ciências Agrārias e Veterinárias - UNESP, "Campus" de Jaboticabal, no periodo de 11 de janeiro a 23 de abril de 1982 .

\section{1 - Instalações e Equipamentos}

0 experimento foi instalado em um galpão com orientação Leste-0este, dividido em 30 baias individuais com 2,50 $\mathrm{m}^{2}$ de ano cada uma. 0 piso do gaTpão era de con creto e comedouro de alvenaria, apresentando uma barra de ferro no sentido transversal, visando evitar perdas de 
69.

racão. Os bebedouros eram do tipo vasos comunicantes.

\section{2 - Animais Utilizados e Manejo}

Foram utilizadas 27 fêmeas, tri-cross (La $\underline{r}$ ge-White $x$ Wessex $x$ Duroc), com idade inicial aproximada de 71 dias.

Os animais permaneceram durante 10 dias em perīodo pré-experimental, com o objetivo de se adaptarem às instalações e ao manejo. Ao término desse perīodo, todos os animais foram pesados e classificados pelos seus pesos em ordem decrescente, sendo, desta forma, divididos em 3 grupos de 9 animais, com pesos semelhantes, os quais constituiram os blocos. No inicio do experimento os animais apresentaram peso médio de $23,86 \mathrm{~kg}$ e foram vacinados contra peste suína e vermifugados.

As baias foram lavadas diariamente e as ra cões fornecidas duas ou mais vezes ao dia, de acordo com o consumo de cada animal. A água foi fornecida à vontade.

\section{3 - Rações Experimentais}

As rações experimentais foram compostas de milho moido, farelo de soja, farelo de arroz engordurado, 
raspa de mandioca integral, suplemento mineral-vitaminico com aditivos, sal iodado, monoamōniofosfato e calcario.Ao farelo de arroz integral foram adicionadas 150 gramas do antioxidante (Etoxiquin). por tonelada com o objetivo de evitar a rancificação.

As rações foram formuladas para conter $15 \%$ de proteína bruta, $0,6 \%$ de cālcio e $0,5 \%$ de fósforo dispó nivel, durante a fase de crescimento $(.23,86$ a $58,29 \mathrm{~kg}$ de peso vivo) e $13 \%$ de proteína bruta, $0,5 \%$ de cálcio e 0,4\% de fósforo disponīvel, durante a fase de acabamento 58,29 a $93,47 \mathrm{~kg}$ de peso vivo), de acordo com as recomendações do NRC (1979).

Os tratamentos experimentais foram os se-

guintes:

$T_{1}$ : Ração basal, constituĩda de milho e farelo de so ja (Ração Testemunha);

$\mathrm{T}_{2}$ : Ração, com $15 \%$ de raspa de mandioca integral e $0 \%$ de farelo de arroz integral;

$\mathrm{T}_{3}$ : Ração, com $30 \%$ de raspa de mandioca integral e $0 \%$ de farelo de arroz integral;

$\mathrm{T}_{4}$ : Ração, com $15 \%$ de farelo de arroz integral e $0 \%$ de raspa de mandioca integral;

$\mathrm{T}_{5}$ : Ração, com $15 \%$ de raspa de mandioca integral e $15 \%$ de farelo de arroz integral; 


\title{
71.
}

\author{
$T_{6}:$ Ração, com $30 \%$ de raspa de mandioca integral e \\ $15 \%$ de farelo de arroz integral; \\ $T_{7}$ : Ração, com $30 \%$ de farelo de arroz integral e $0 \%$ \\ de raspa de mandioca integral; \\ $T_{8}:$ Ração, com $15 \%$ de raspa de mandioca integral e \\ $30 \%$ de farelo de arroz integral; \\ $T_{9}$ : Ração, com $30 \%$ de raspa de mandioca integral e \\ $30 \%$ de farelo de arroz integral.
}

A composição quîmica aproximada dos ingredientes das rações experimentais é apresentada na Tabela 26 e a composição dos aminoácidos na Tabela 27.

As composições percentuais das racões expe rimentais na fase de crescimento, e na fase de acabamento e dos suplementos mineral vitamínico com aditivos sãoapre sentados nas Tabelas 28,29 e 30 , respectivamente.

As rações foram preparadas na Fábrica de Rações da Faculdade de Ciências Agrārias e Veterinārias UNESP, "Campus" de Jaboticabal, e distribuídas em tambores plásticos, com capacidade para 30 litros. 
72.

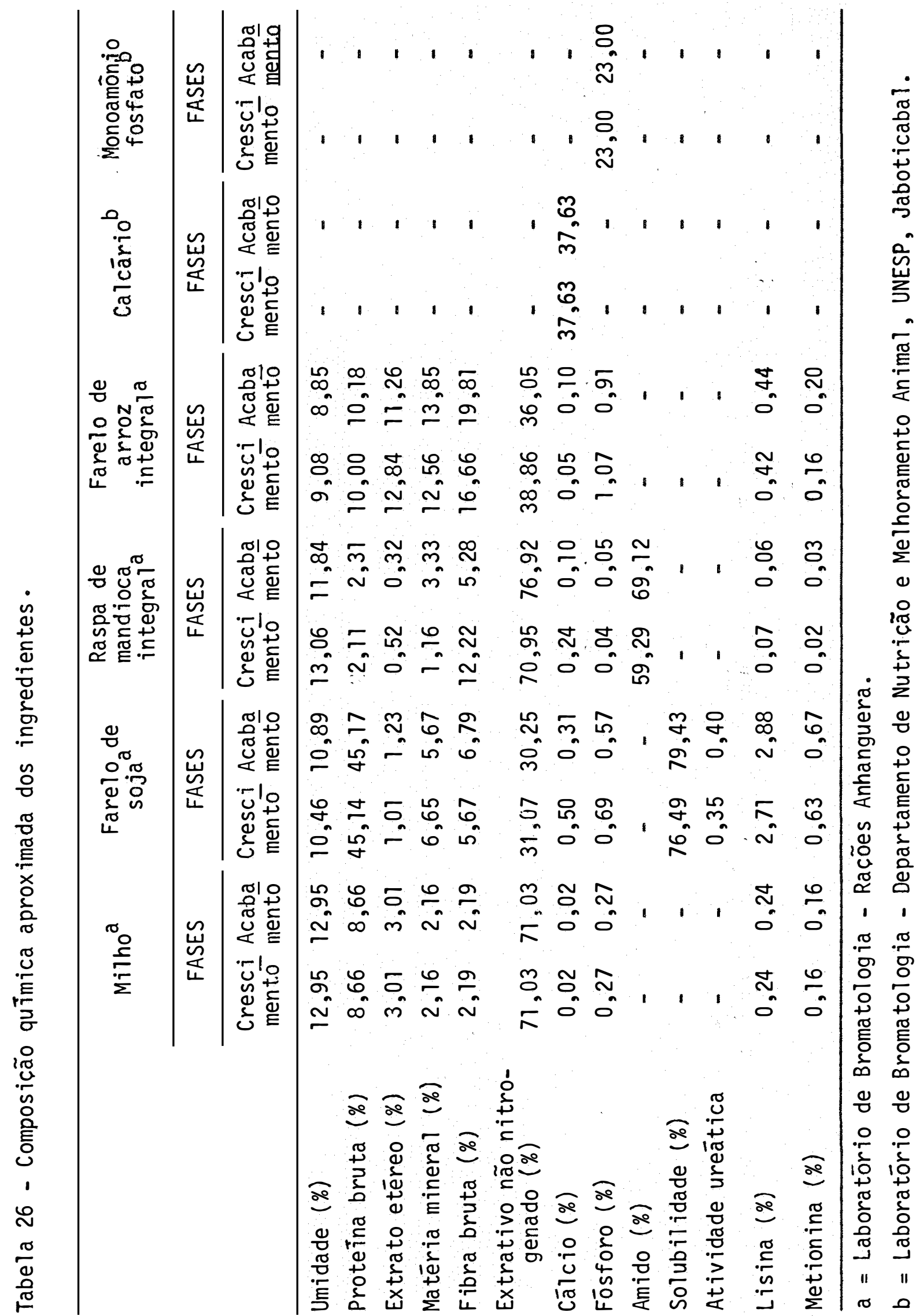


73.

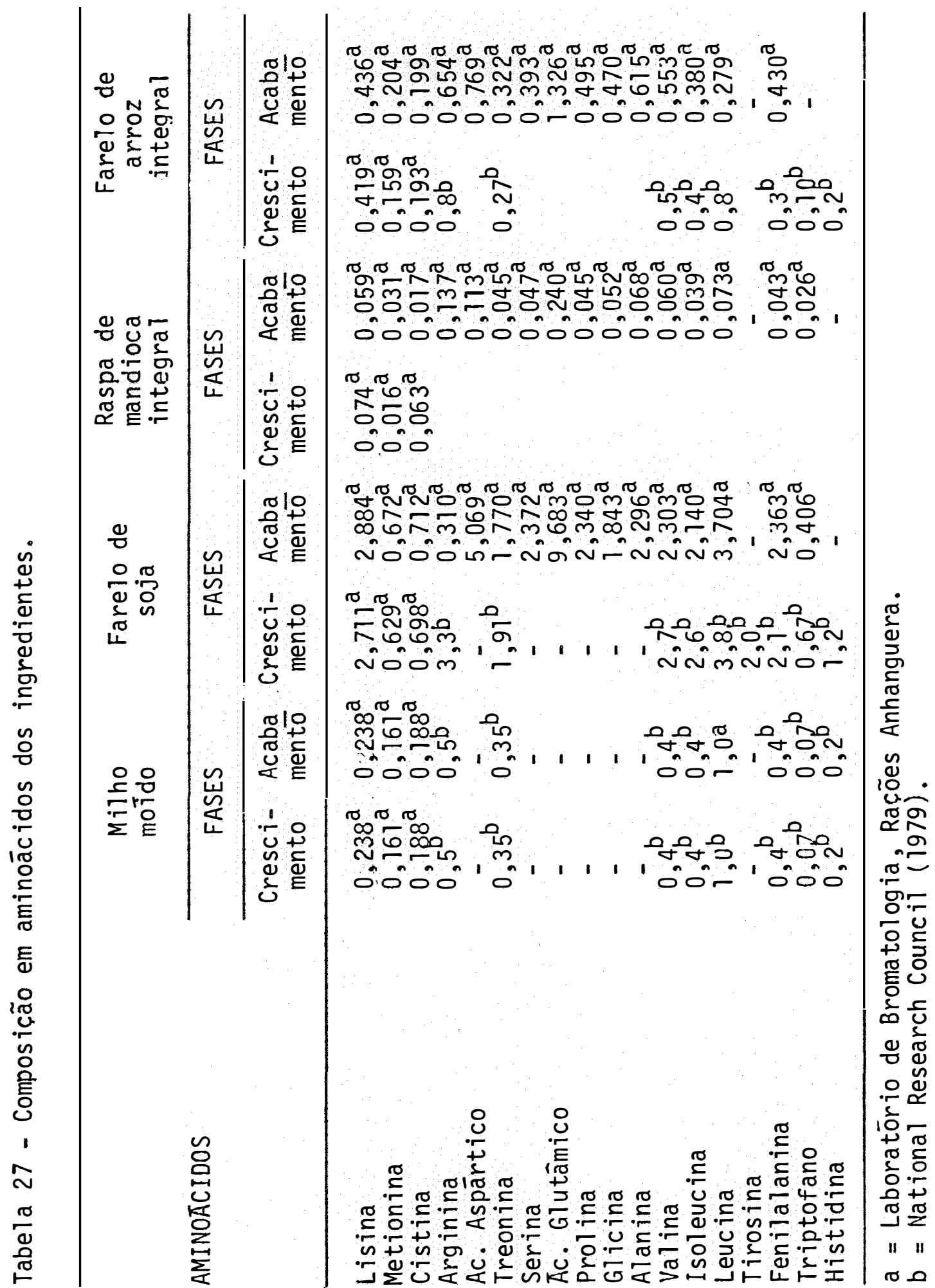


74.

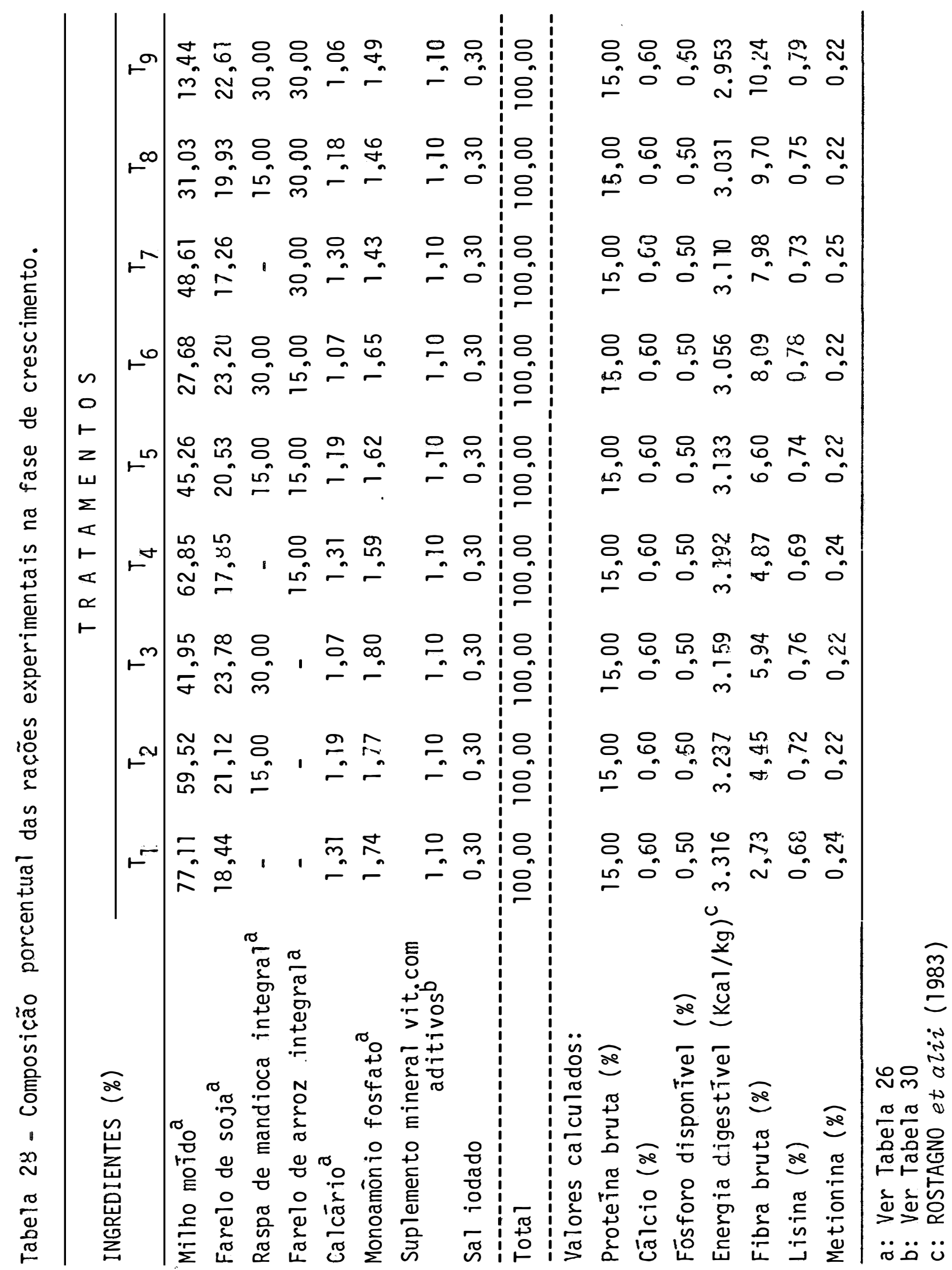




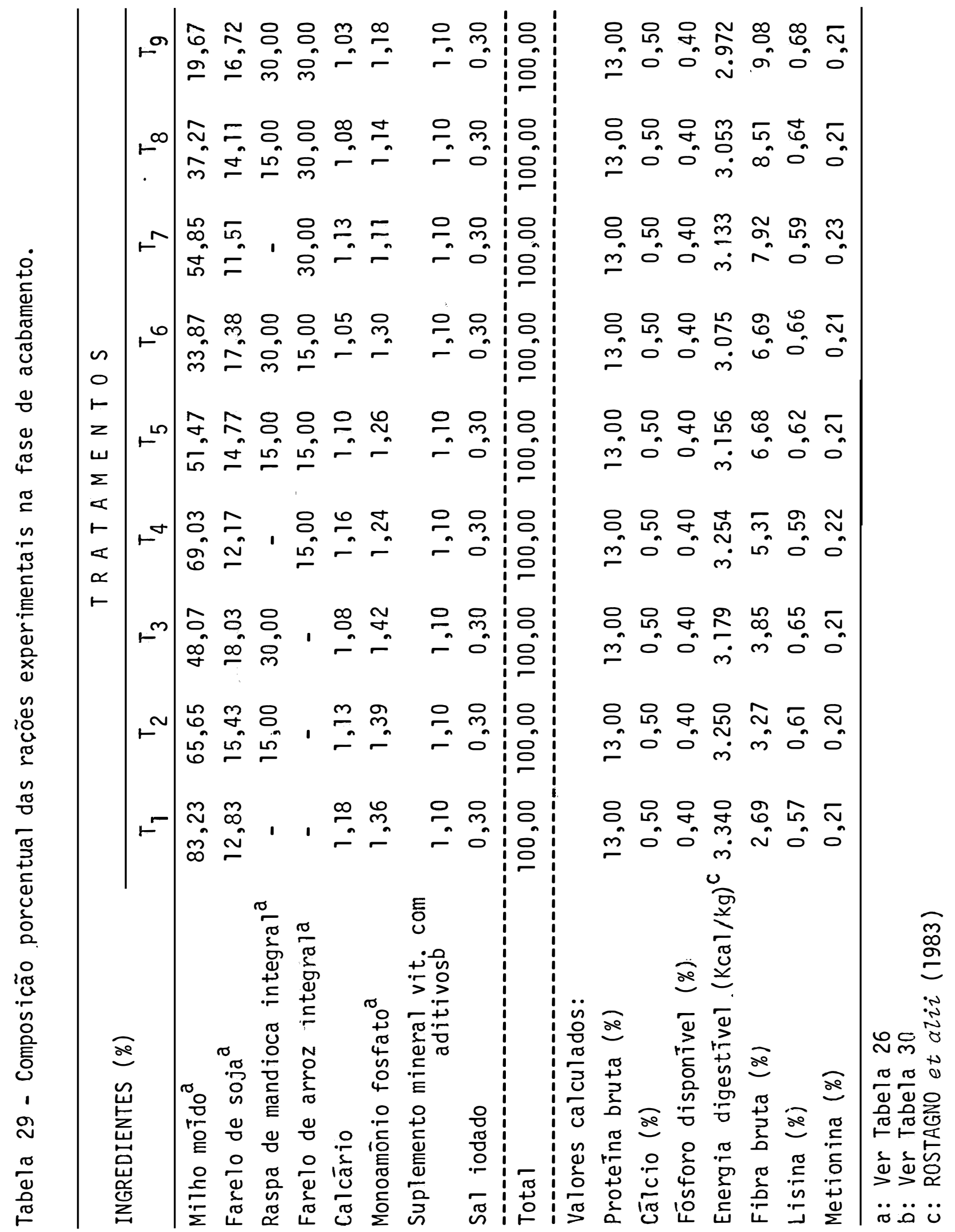


Tabela 30 - Composição do suplemento mineral, vitamĩnico, com aditivos utilizados nas rações experimentais, nas fases de crescimento e acabamento(*)

\begin{tabular}{|c|c|c|}
\hline \multirow{2}{*}{ NUTRIENTES E ADITIVOS } & \multicolumn{2}{|c|}{ FASES DA CRIACAAO } \\
\hline & Crescimento & Acabamento \\
\hline Vitamina $A$ estabilizada & 750.000 UI & 500.000 UI \\
\hline Vitamina $D_{3}$ estabilizada & $125.000 \mathrm{UI}$ & 75.000 UI \\
\hline Vitamina E estabilizada & $2.500 \mathrm{mg}$ & $1.500 \mathrm{mg}$ \\
\hline Vitamina $K_{3}$ estabilizada & $225 \mathrm{mg}$ & $125 \mathrm{mg}$ \\
\hline Tiamina & $150 \mathrm{mg}$ & $100 \mathrm{mg}$ \\
\hline Riboflavina & $300 \mathrm{mg}$ & $200 \mathrm{mg}$ \\
\hline Piridoxina & $225 \mathrm{mg}$ & $150 \mathrm{mg}$ \\
\hline Vitamina $B_{12}$ & $0,01 \mathrm{mg}$ & $0,007 \mathrm{mcg}$ \\
\hline Biotina & $0,05 \mathrm{mg}$ & $0,03 \mathrm{mg}$ \\
\hline Ácido pantoténico & $1.125 \mathrm{mg}$ & $750 \mathrm{mg}$ \\
\hline Acido nicotĩnico & $1.500 \mathrm{mg}$ & $1.000 \mathrm{mg}$ \\
\hline Acido fólico & $30 \mathrm{mg}$ & $30 \mathrm{mg}$ \\
\hline Col ina & $15.000 \mathrm{mg}$ & $15.000 \mathrm{mg}$ \\
\hline Iodo & $0,10 \mathrm{~g}$ & $0,10 \mathrm{~g}$ \\
\hline Cobal to & $0,05 \mathrm{~g}$ & $0,05 \mathrm{~g}$ \\
\hline Manganēs & $4,5 \mathrm{~g}$ & $4,5 \mathrm{~g}$ \\
\hline Ferro & $8,8 \mathrm{~g}$ & $8,8 \mathrm{~g}$ \\
\hline Cobre & $1,5 \mathrm{~g}$ & $1,5 \mathrm{~g}$ \\
\hline Zinco & $8,0 \mathrm{~g}$ & $8,0 \mathrm{~g}$ \\
\hline Selēnio. & $0,015 \mathrm{~g}$ & $0,015 \mathrm{~g}$ \\
\hline Antibiōtico & $4.000 \mathrm{mg}$ & $4.000 \mathrm{mg}$ \\
\hline Antioxidante & $5.000 \mathrm{mg}$ & $5.000 \mathrm{mg}$ \\
\hline Veīculo protéico e energētico & $1.000 \mathrm{~g}$ & $1.000 \mathrm{~g}$ \\
\hline
\end{tabular}

observação: Composição para cada $1.000 \mathrm{~g}$ do produto.

(*) Suplemento mineral vitaminico com aditivos-Supre-mais. 


\section{4 - Abate dos Animais e Avaliação de Carcaça}

Ao término do período experimental, os an $\underline{i}$ mais foram abatidos, apōs 24 horas de jejum de alimento sōlido e 12 horas de jejum de àgua.

Após o abate, os animais foram depilados, eviscerados e cortados ao meio longitudinalmente. Em segui da, as meias carcaças foram pesadas e conservadas em câma ra frigorifica a $-2^{\circ} \mathrm{C}$, onde permaneceram por 24 horas.

Os pesos e as medidas referentes às carcacas foram tomadas na meia carcaca esquerda, segundo o Método Brasileiro de Classificacão de Carcacas adotado pela Associação Brasileira dos Criadores de Suínos (1973).

os dados coletados, para posterior estudo referente à qualidade da carcaca, foram os seguintes:

- Comprimento da carcaca: tomado do bordo cranial da sinfese pubiana ao bordo crānio-ventral do atlas;

- Espessura do toicinho: média das espessuras de toi cinho tomadas na primeira vērtebra toráxica, na ū tima vērtebra torāxica e na ūitima vērtebra lombar;

- Arrea de olho do lombo: area da seccão transversal do músculo Zongissimus dorsi, entre a ūltima vérte bra torāxica e a primeira vērtebra lombar; 
- Relacão gordura:carne: é o quociente da ārea da co bertura de gordura correspondente ao olho de lombo pela área de olho de lombo;

- Percentagem de pernil: é a relacão percentual do peso dos pernis para com o peso da carcaca. Para obter o peso do pernil foi feito um corte perpendi cular à linha dorsal na altura da articulação entre a ūitima e a penūitima vértebras lombares;

Um outro dado obtido, relacionado coma qua lidade da carcaça, foi o rendimento de carcaça, que é a relação percentual entre o peso da carcaça fria (minimode 24 horas em camara fria a $-2^{\circ} \mathrm{C}$ ) e o peso de abate do anima 1

3.5 - Dados de Desempenho e de Carcaça Estudados

Após o término do experimento, abate dos animais, analisaram-se os seguintes dados:

\subsection{1 - Consumo de ração}

os dados referentes ao consumo de ração foram obtidos a cada 14 dias, a partir do início do experi-mento até o término, num total de 102 dias, sendo o ūt timo perỉodo de 4 dias. 


\subsection{2 - Ganho de peso..}

Dados obtidos durante as fase de crescimen to, acabamento e crescimento + acabamento.

\subsection{3 - Conversão al imentar}

os dados foram obtidos dividindo-se o consumo de ração pelo ganho de peso, para cada animal identí ficado em cada tratamento e em cada bloco.

\subsection{4 - Características de carcaça}

Foram estudados os dados referentes ao com primento de carcaça, espessura de toicinho, área de olho do lombo, relação gordura:carne, percentagem de pernil e rendimento de carcaça.

\section{6 - Del ineamento Experimental}

0 delineamento experimental adotado foi 0 de blocos ao acaso, com 9 tratamentos, 3 repetições, em esquema fatorial com 3 níveis $(0,15$ e $30 \%)$ de substituição de farelo de arroz e 3 nĩveis $(0,15$ e $30 \%)$ de substituição de raspa de mandioca.

os dados de consumo de ração, ganho de peso e conversão alimentar, foram submetidos a anālise de variância. Os dados referentes às características de carcaça, foram submetidos a anālise de covariância, para que os mesmos fossem ajustados a um mesmo peso de abate dos animais $(90,25 \mathrm{~kg})$. 
Tanto para os dados de desempenho, como para os de caracteristicas de carcaça, a soma de quadrado dos fatores foi decomposta nos graus de liberdade individuais de regressão linear e quadrática, atravēs de polinōmios ortogonais. 
81.

\section{RESULTADOS E DISCUSSÃO}

\section{1 - Desempenho}

$$
\text { 4.1.1 - Consumo de ração }
$$

A Tabela 31 apresenta os consumos médios de racao, durante o perīodo experimental, pelos suỉnos sub metidos aos nove diferentes tratamentos.

$$
\text { os consumos de ração dos lotes de suínos, }
$$
nos vārios periodos são mostrados na Tabela A-1, no Apẽndice.

Na Tabela 32 são apresentados os dados de consumo de ração, pelos suínos nas fases de crescimento, acabamento e crescimento-acabamento, e na Tabela 33 o con sumo diārio e os indices relativos nas referentes fases. 
82.

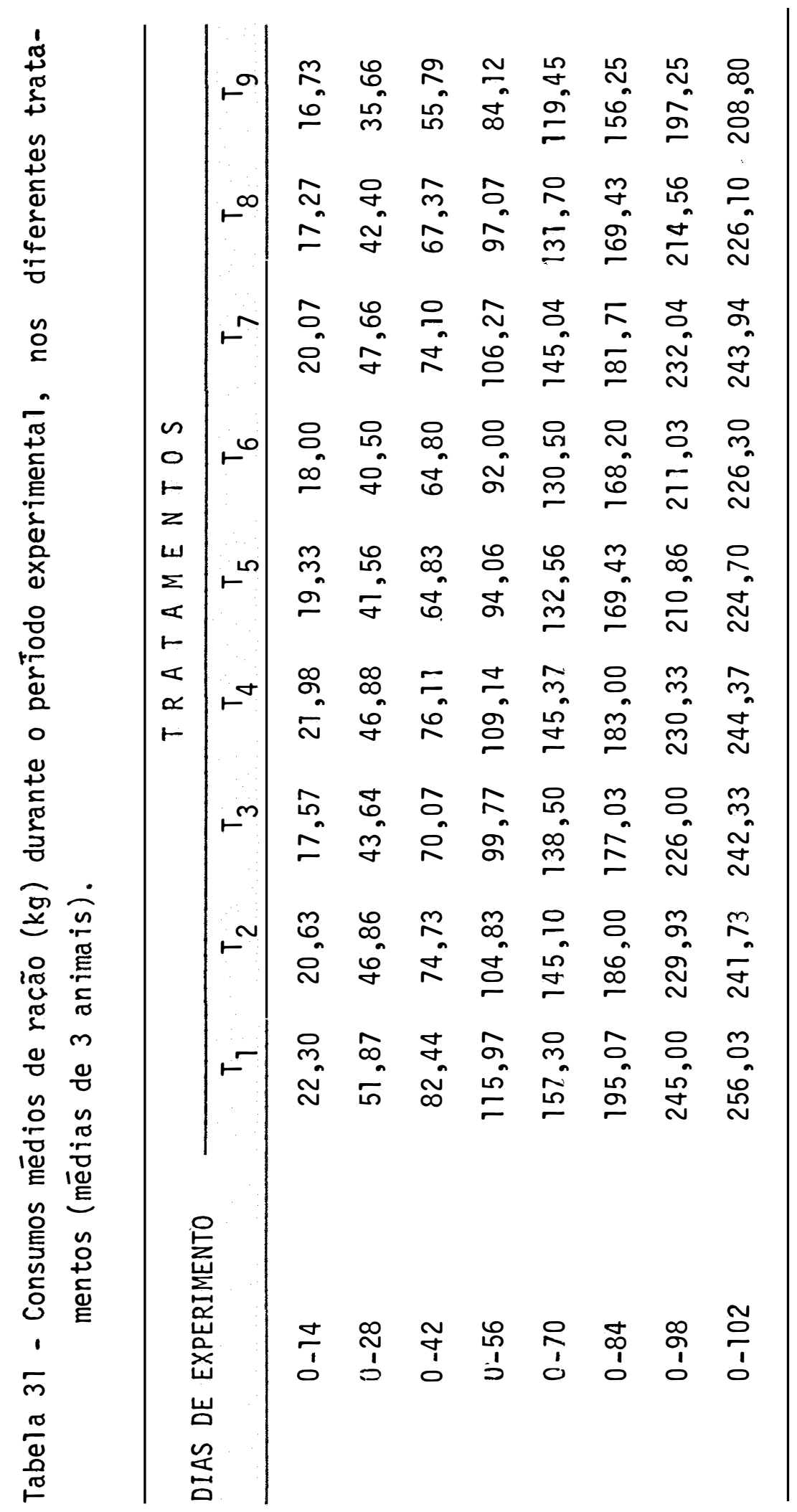


83.

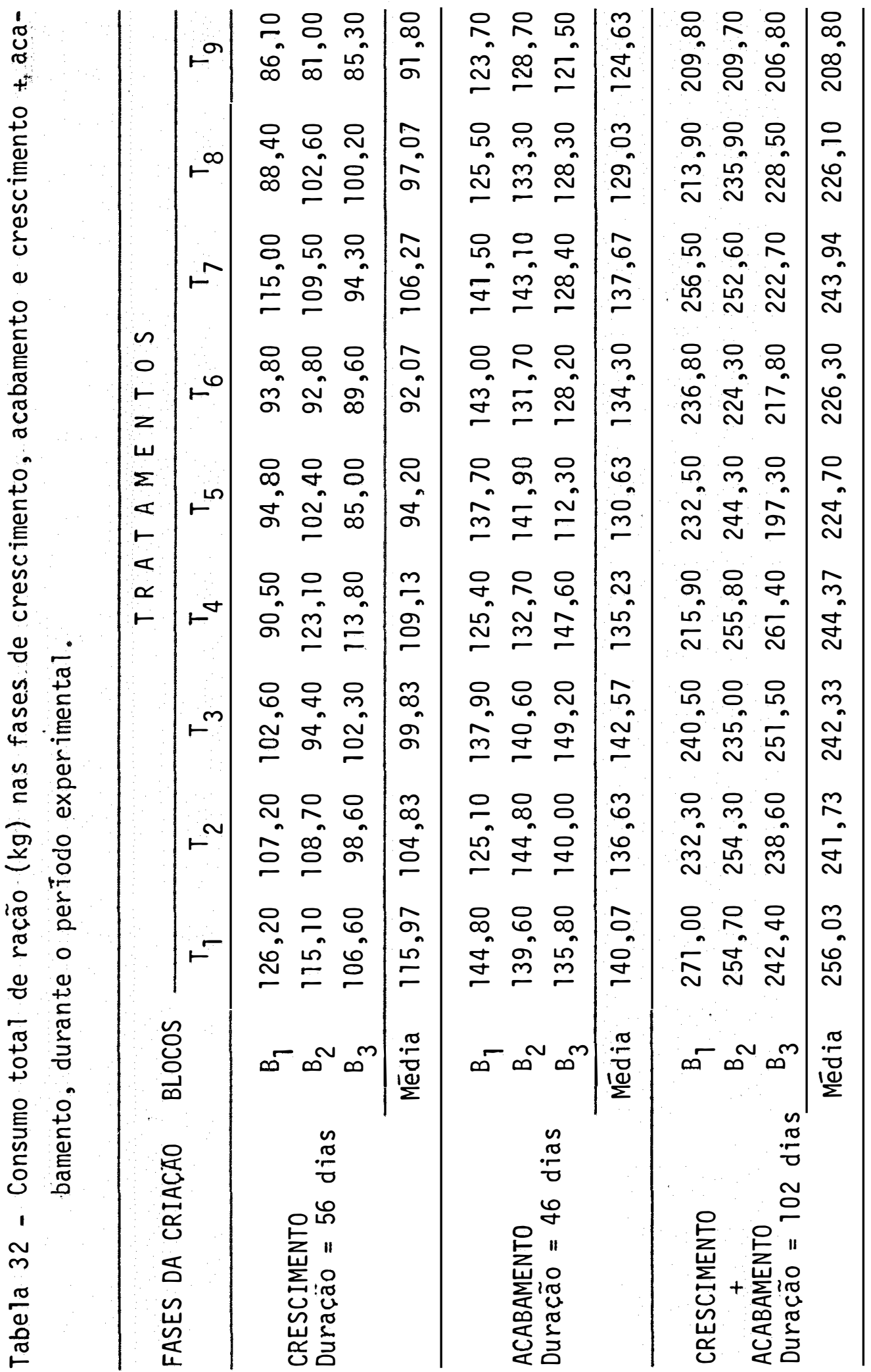


84.

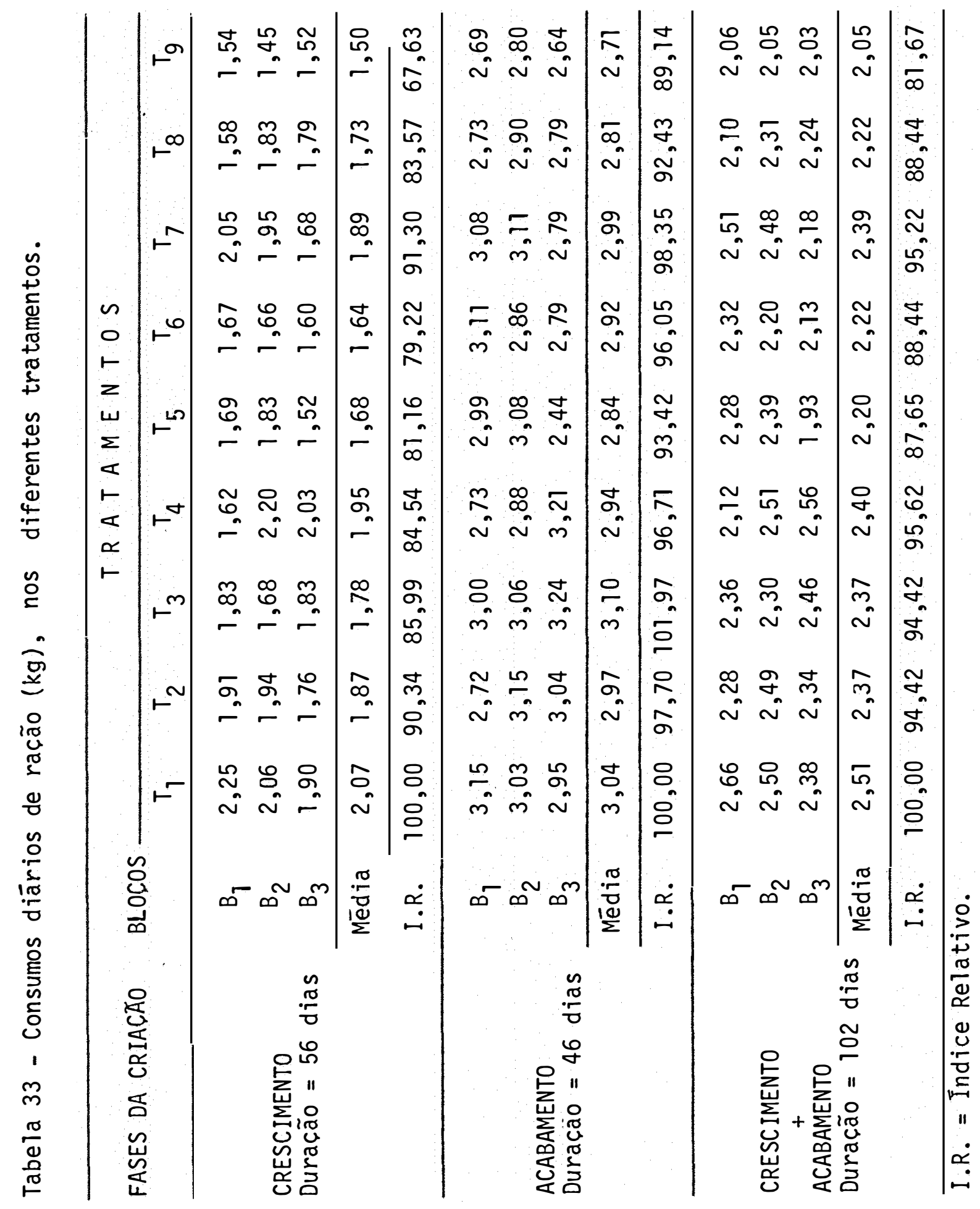


A Figura 4 apresenta os histogramas de con sumo diārio de ração dos animais submetidos aos diferentes tratamentos.

As anālises de variância dos dados de consumo diārio de ração, nas fases em estudo, são apresentadas na Tabela 34.

Para a fase de crescimento, as anālises de variāncia mostraram efeito significativo $(P<0,05)$ dos tratamentos sobre o consumo diārio de ração, como também para os niveis de farelo de arroz $(P<0,05)$ e raspa de mandioca $(P<0,01)$. Quando os graus de liberdade dos $n \bar{i}-$ veis de farelo de arroz e raspa de mandioca foram decompostos em seus componentes linear e quadrático, houve res posta 1 inear negativa sobre consumo diário de ração com o aumento dos níveis de farelo de arroz ou raspa de mandioca. As equacões de regressão para farelo de arroz e raspa da mandioca foram, respectivamente,

$$
P=1,8889-0,0065 x
$$

e

$$
P=1,9550-0,0109 x,
$$

as quais estão representadas na Figura 5. Através das equa cöes obtidas, é possível observar que a raspa de mandioca foi o ingrediente que mais afetou o consumo de racão, pois a ca da $1 \%$ de raspa de mandioca incluído na ração, houve uma 
86.

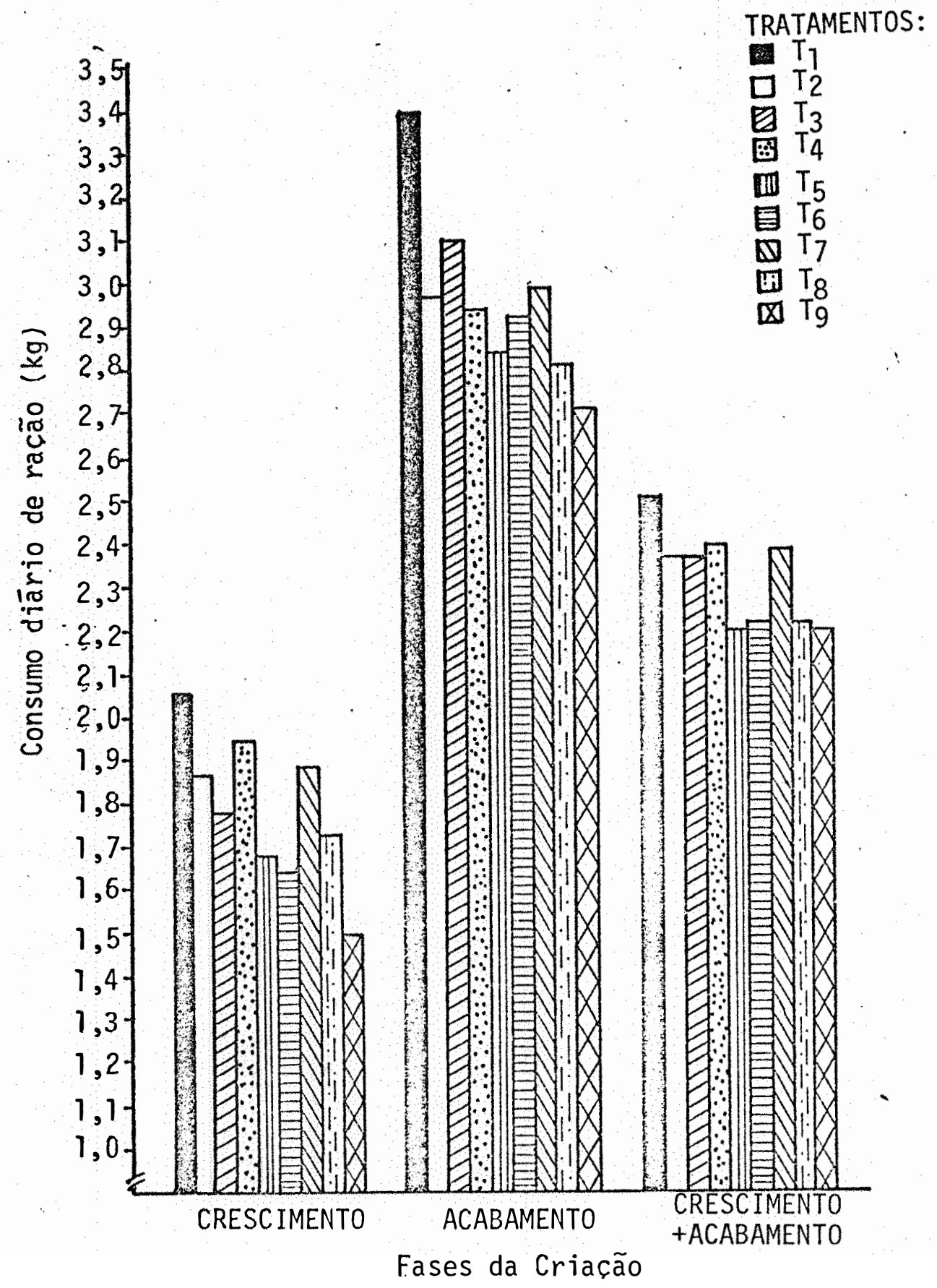

Figura 4 - Representação, atravēs de histogramas, dos consumos diārios de ração $(\mathrm{kg})$, pelos suinos durante as fases de cres cimento, acabamento e crescimento-acabamento. 


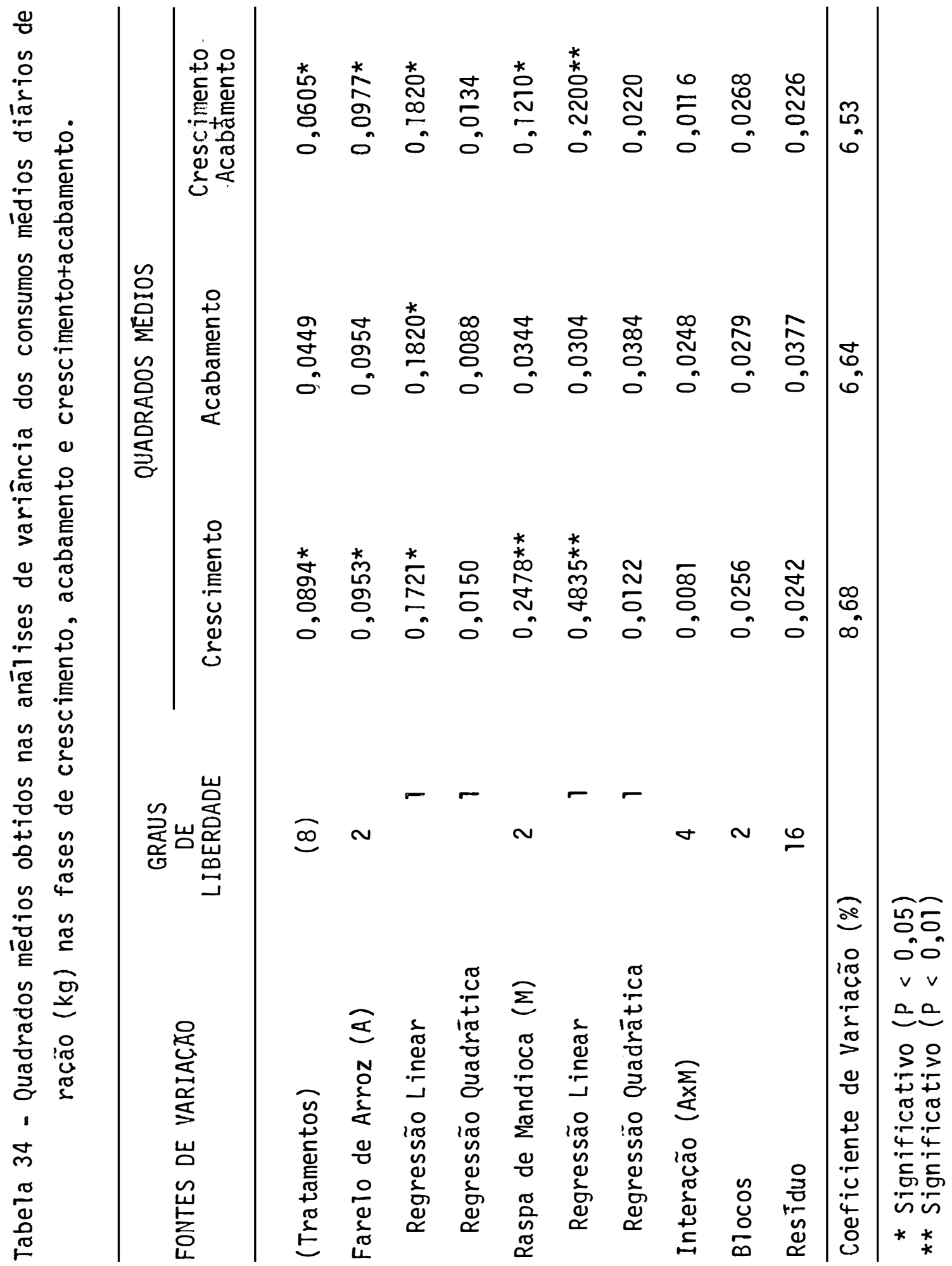


83.

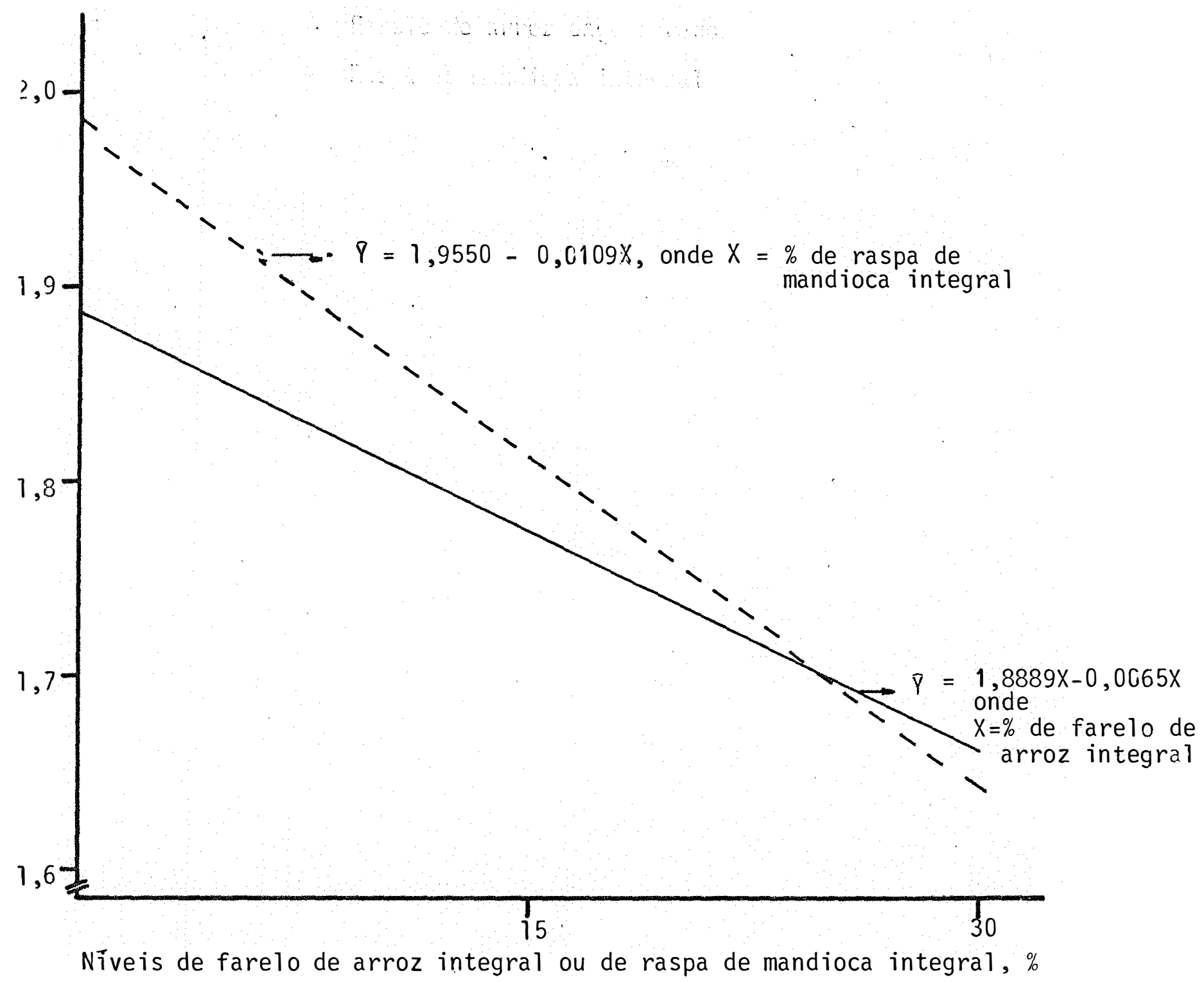

Figura 5 - Efeitos dos nîveis de farelo de arroz integral e de raspa de mandioca integral na ração, sobre o consumo diārio de ração $(\mathrm{kg})$ dos suĩnos, na fase de crescimerito. 
diminuição no consumo de 0,0109 , enquanto que para o fare10 de arroz a diminuição foi de 0,0065.

As anālises de variāncia não mostraramefei to significativo $(P>0,05)$ para tratamentos na fase de acabamento, como também para níveis de farelo de arroz ou raspa de mandioca. Entretanto, obteve-se resposta linear negativa $(P<0,05)$ para o farelo de arroz, sendo a equação linear representada por

$$
\nabla=3,0250-0,0067 x,
$$

a qual está representada na Figura 6 .

Para a fase de crescimento-acabamento, as anālises de variância mostraram efeito significativo para níveis de farelo de arroz $(P<0,05)$ e raspa de mandioca $(P<0,05)$. A decomposição dos graus de liberdade,mostrou resposta linear negativa do consumo de racão tanto para farelo de arroz $(P<0,05)$ como para raspa de mandioca $(P<0,01)$. As equações foram, respectivamente,

$$
P=2,4031-0,0067 x
$$

e

$$
P=2,4131-0,0074 x \text {, }
$$

as quais estão representadas na Figura 7. Através das equa cões apresentadas, é possível observar que a raspa de mandioca foi o ingrediente que mais afetou o consumo de racão, de maneira anāloga à fase de crescimento. 
90.

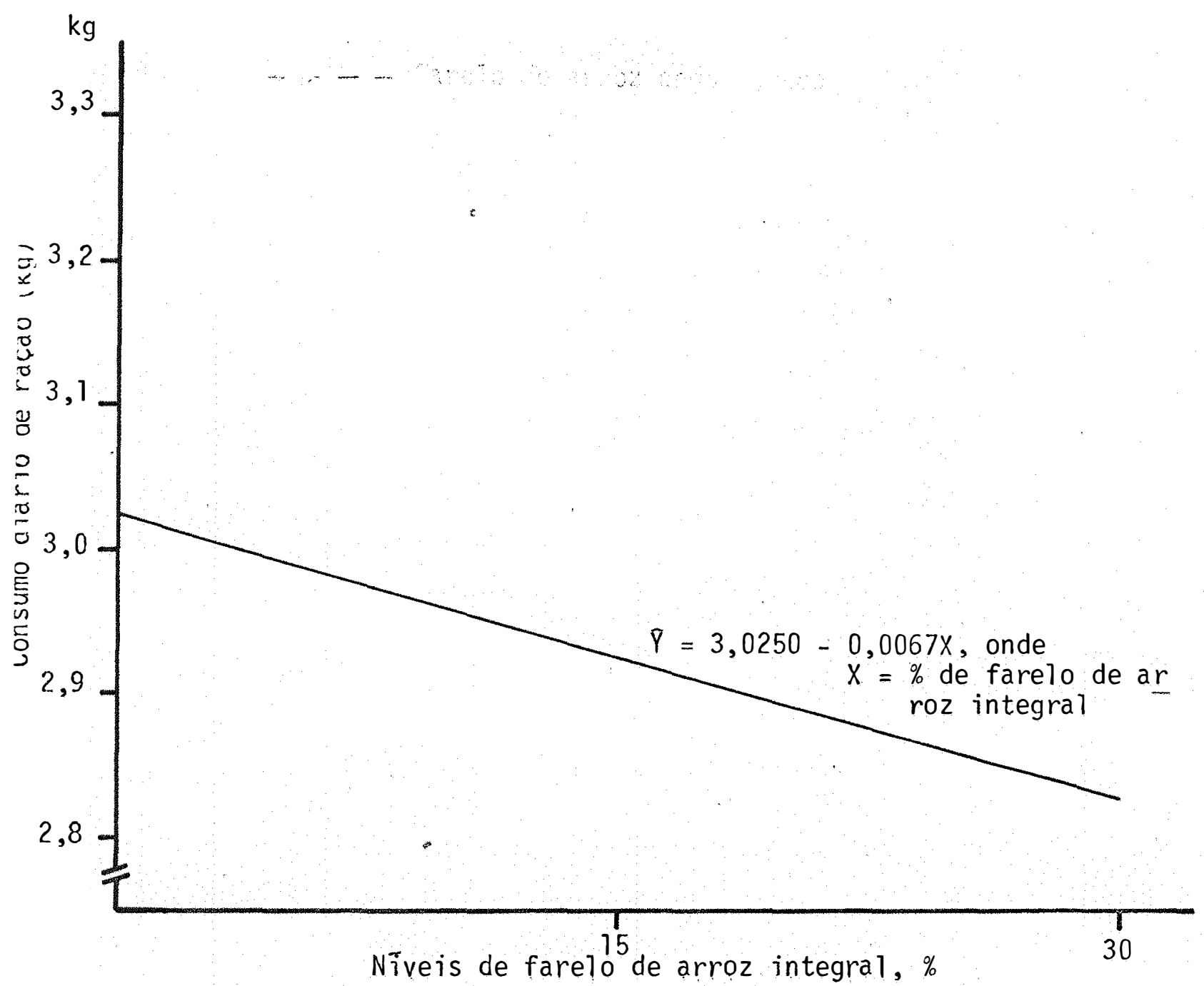

Figura 6 - Efeitos dos niveis de farelo de arroz antegral na ração, sobre o consumo diário de ração $(\mathrm{kg})$ dos suinos, durante a fase de acabamento. 


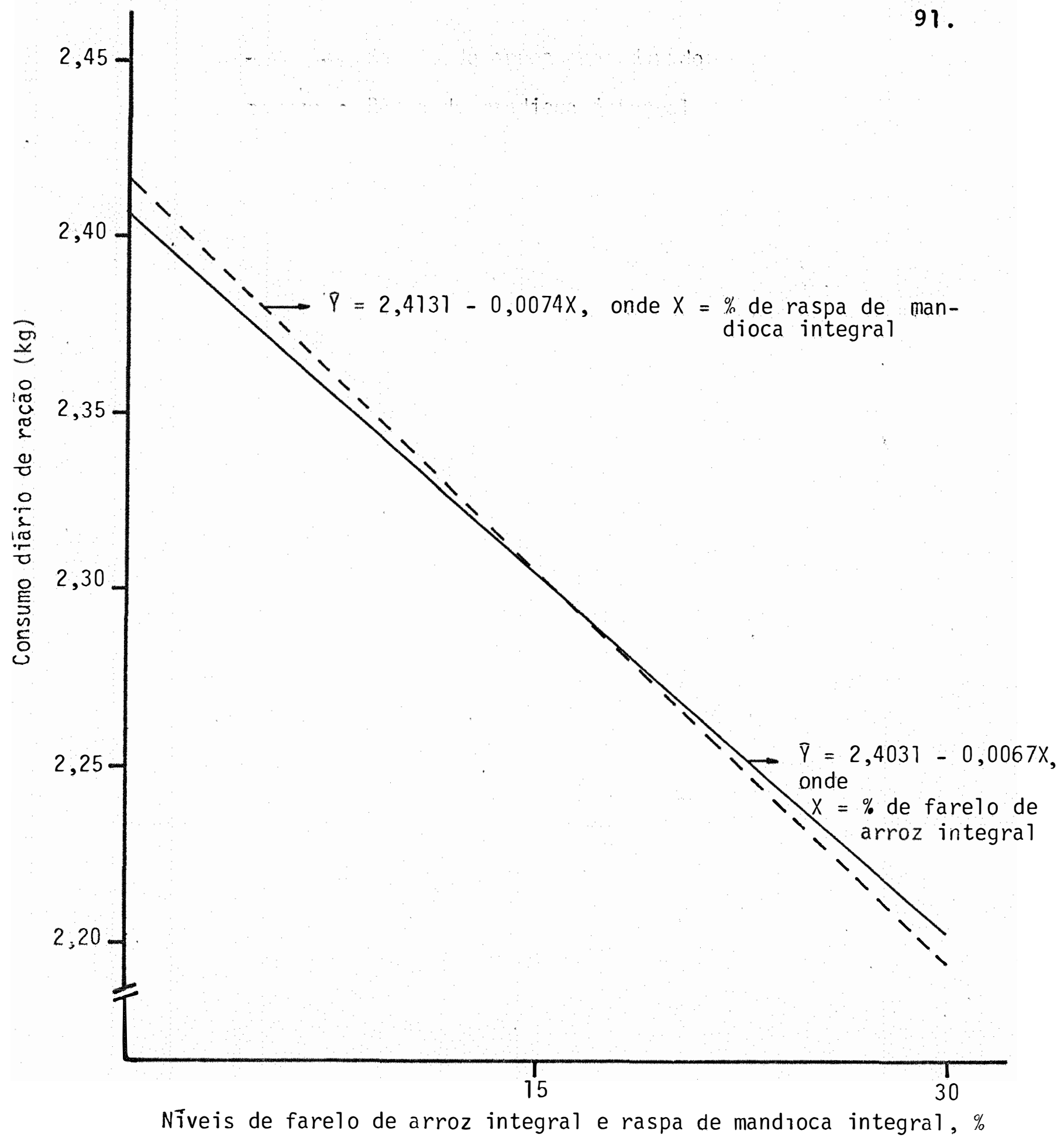

Figura 7 - Efeitos dos niveis de farelo de arroz integral e raspa de mandioca integral na ração, sobre o consumo diārio de ra cão $(\mathrm{kg})$ dos suĩnos, durante a fase de crescimento-acabamento. 
Considerando-se os dados obtidos, diferem dos apresentados por NOLAND e SCOTT (1963). Entretanto os dados são semelhantes aos apresentados por SHARDA et alii (1977), que observaram uma tendēncia de diminuicão do con sumo de ração com a inclusão de nīveis crescentes de fare 10 de arroz. ROJAS e BRAVO (1971), constataram uma tendēn cia de aumento do consumo na fase de crescimento, e para a de acabamento o consumo diminuiu com a adicão do farelo de arroz.

Para a raspa de mandioca, os resultados e $\underline{s}$ tão de acordo com os apresentados PEIXOTO (1965) e PEIXOTO e ISLABÃO (1969), que relataram uma diminuicão do consumo de ração pelos suĩnos com o aumento dos nîveis do re ferido ingrediente.

mo diário de ração pelos suínos nas fases em estudo, pode ser atribuída: ao fato de ocorrer um aumento do teor de fí bra na racão, com os crescentes níveis de farelo de arroz e raspa de mandioca, como pode ser observado nas Tabelas 28 e 29. No que se refere à inclusão de raspa de mandioca à racão, este ingrediente foi o que mais afetou o consumo, provavelmente devido à sua textura pulverulenta (PEIXOTO e ISLABR̃O, 1969). 


\subsection{2 - Ganho de peso}

os pesos individuais dos suínos no decorrer do experimento são apresentados na Tabela A-2, no Apēn dice. A Tabela 35 mostra os pesos médios dos suinos durante o período experimental.

os ganhos de pesos dos suinos no período de 14 dias estão na Tabela A-3, no Apêndice. Os dados refé rentes ao ganho de peso dos animais nas fases de crescimen to, acabamento e crescimento-acabamento sāo apresentados na Tabela 36. A Tabela 37 apresenta os dados de ganho diārio de peso e os indices relativos, nas fases em estudo, e a Figura 8 mostra a representação desses ganhos diārios de peso, na forma de histogramas.

As anālises de variância do ganho diārio de peso dos suinos nas fases de crescimento, acabamento, e crescimento-acabamento, são apresentadas na Tabela 38 . 
94.

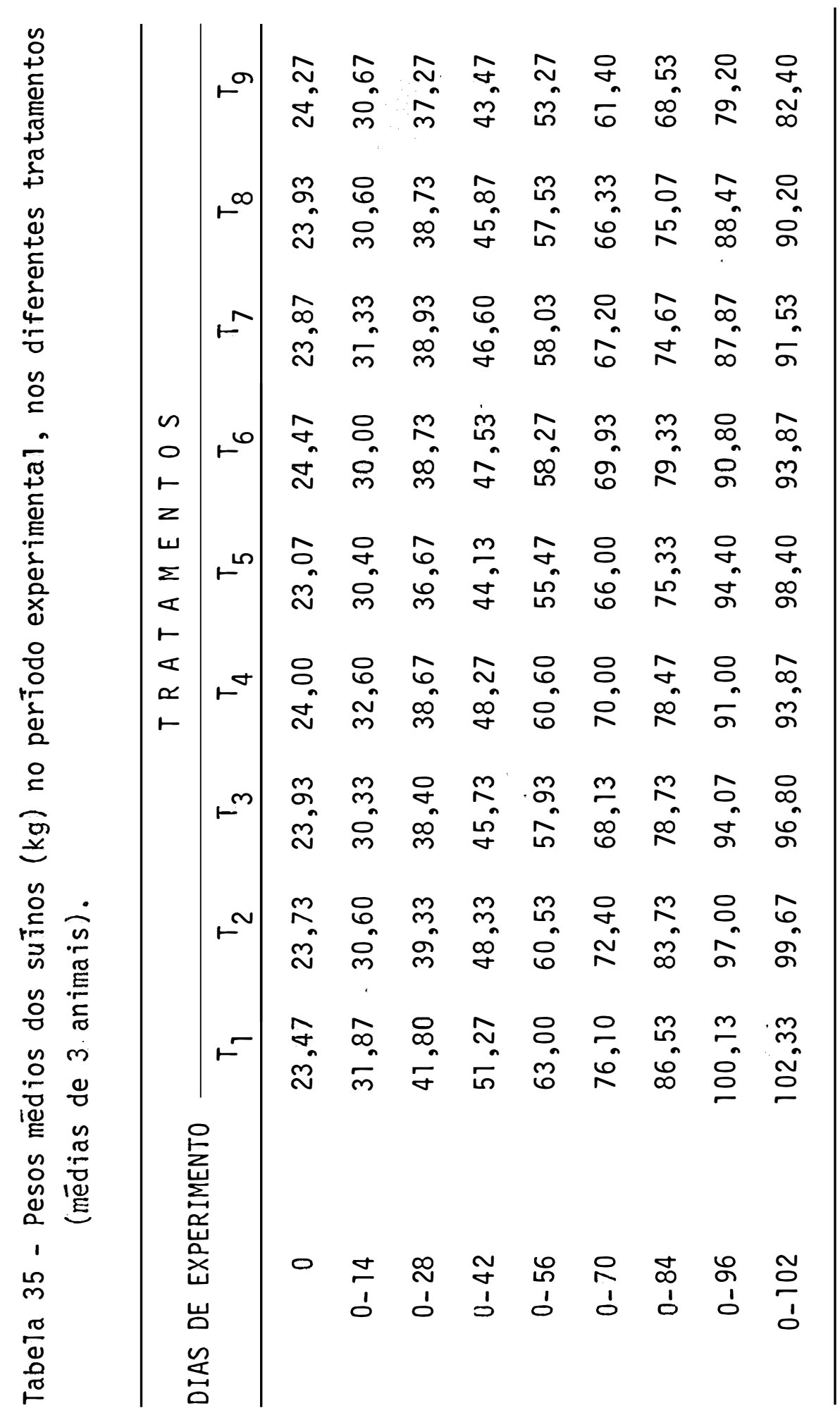




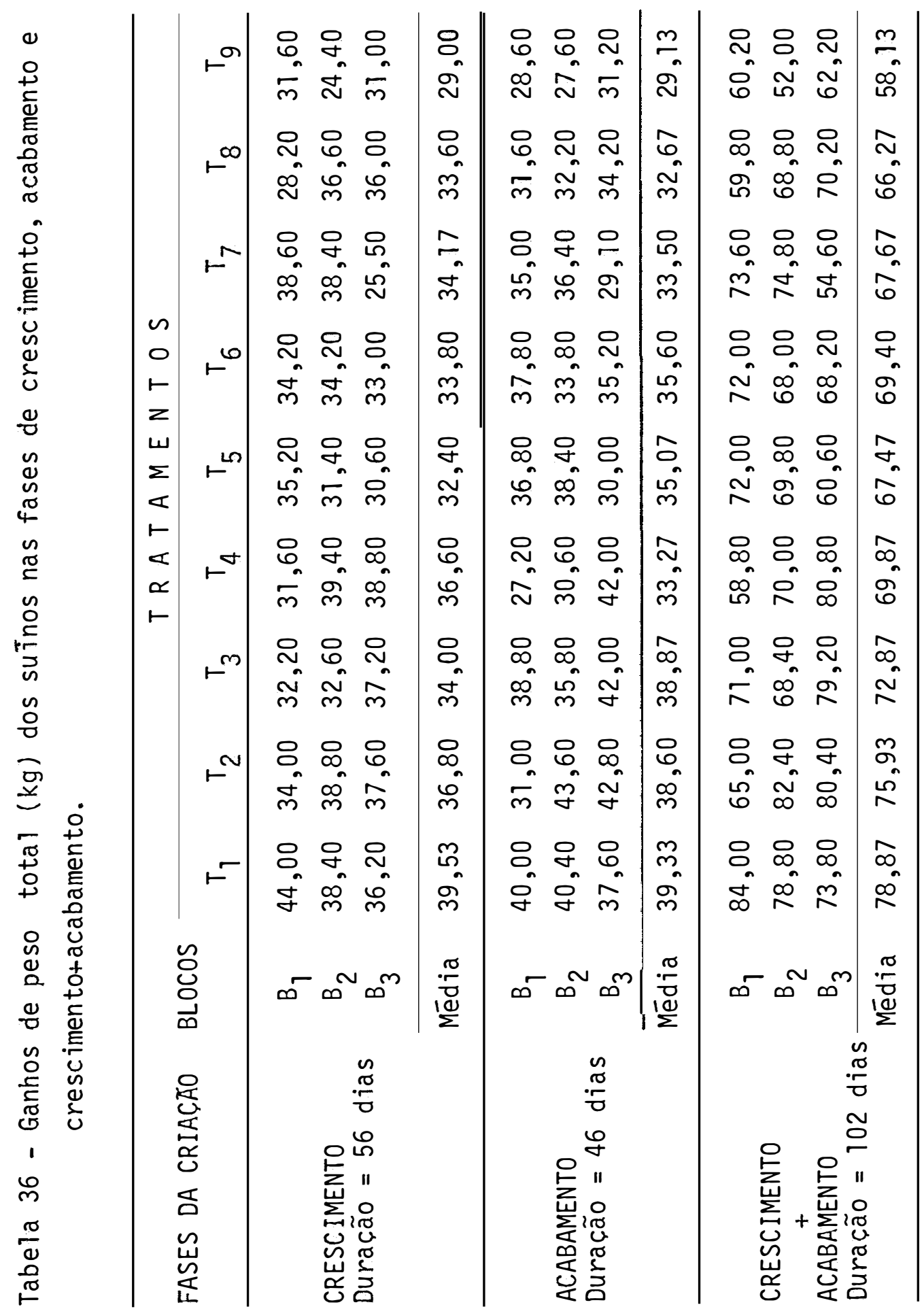




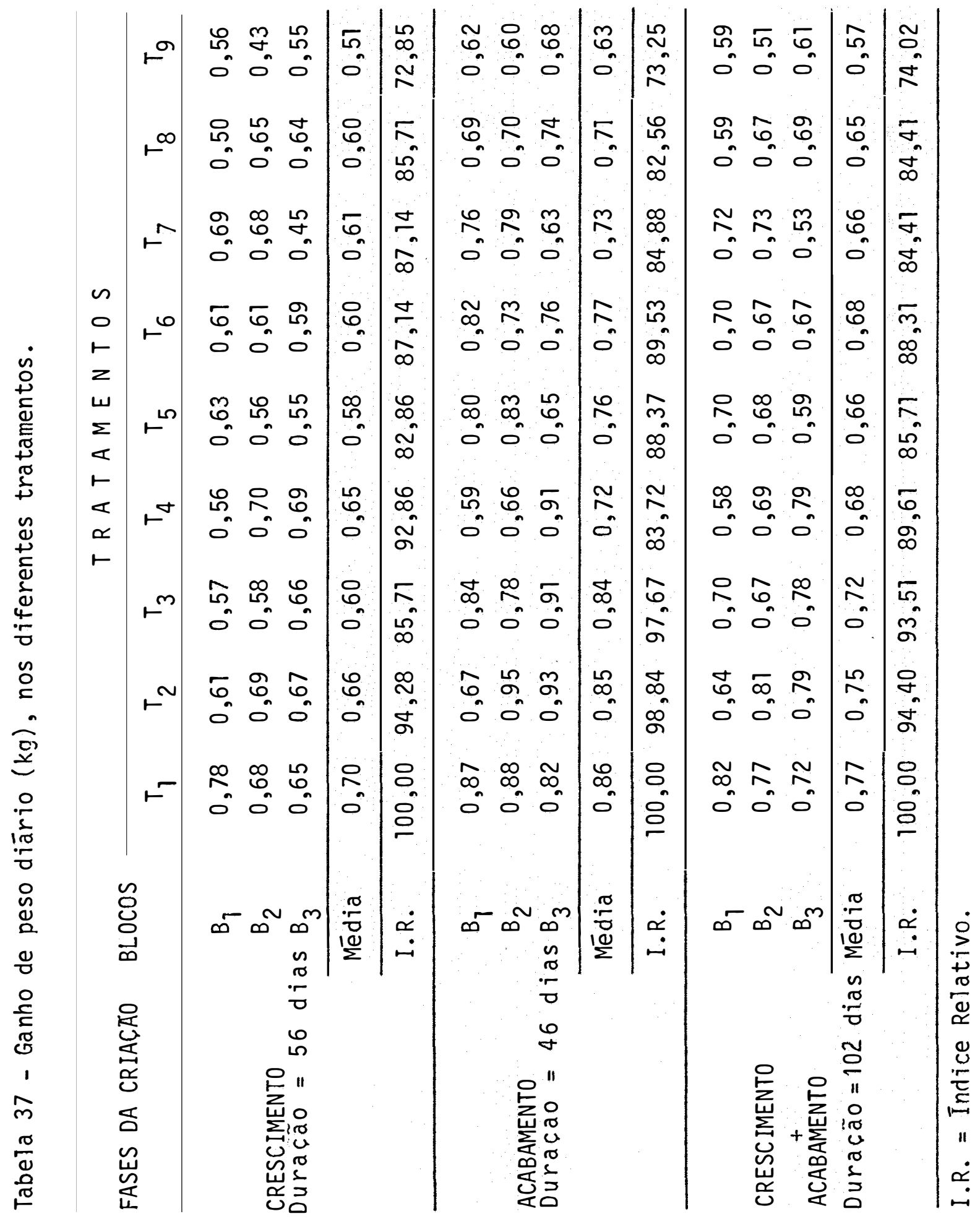


97.

TRATAMENTOS:

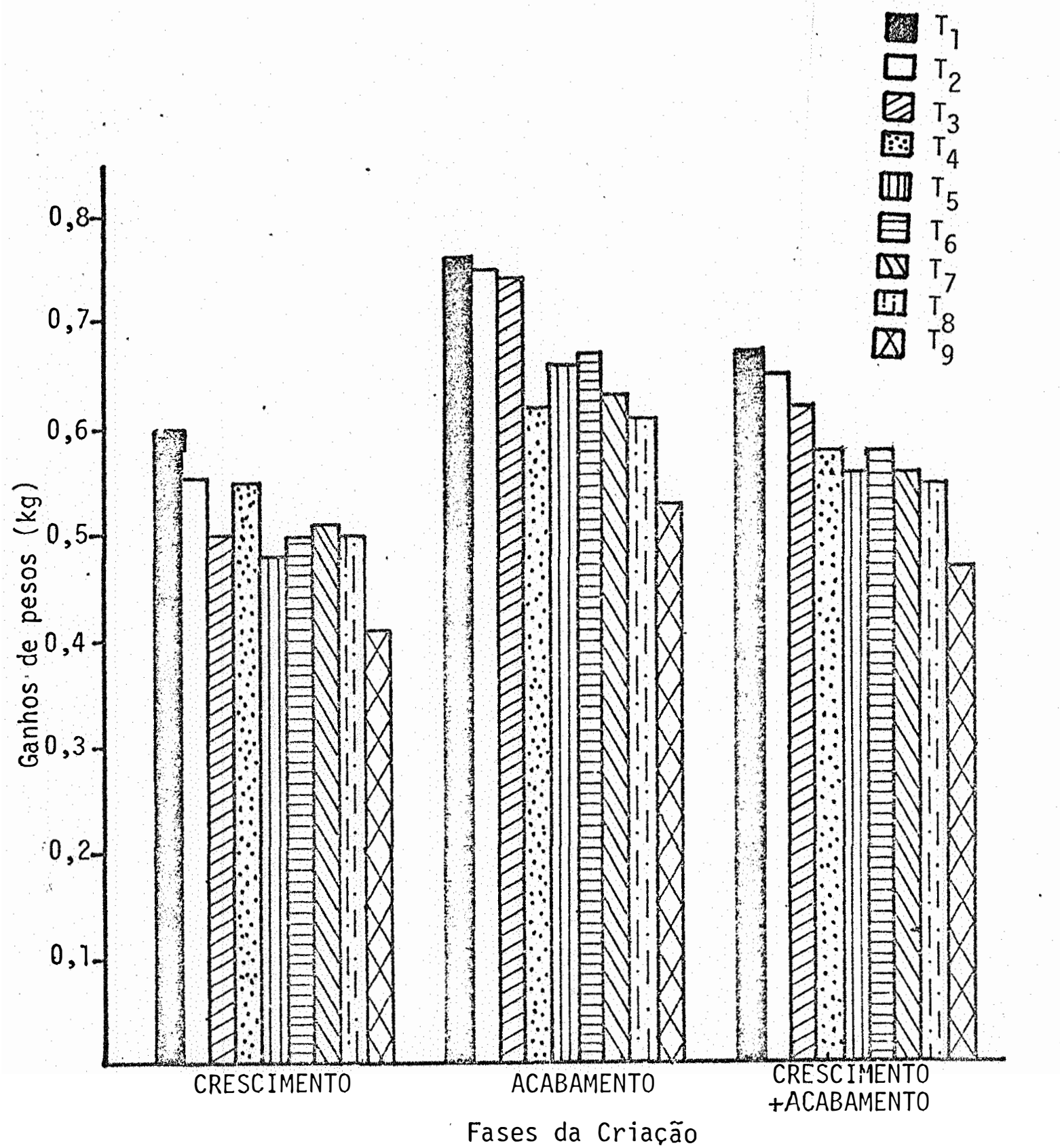

Figura 8 - Representação, através de histogramas, dos ganhos diārios de pesos $(\mathrm{kg})$ pelos suinos, durante as fases de crescimento, acabamento e crescimentotacabamento. 


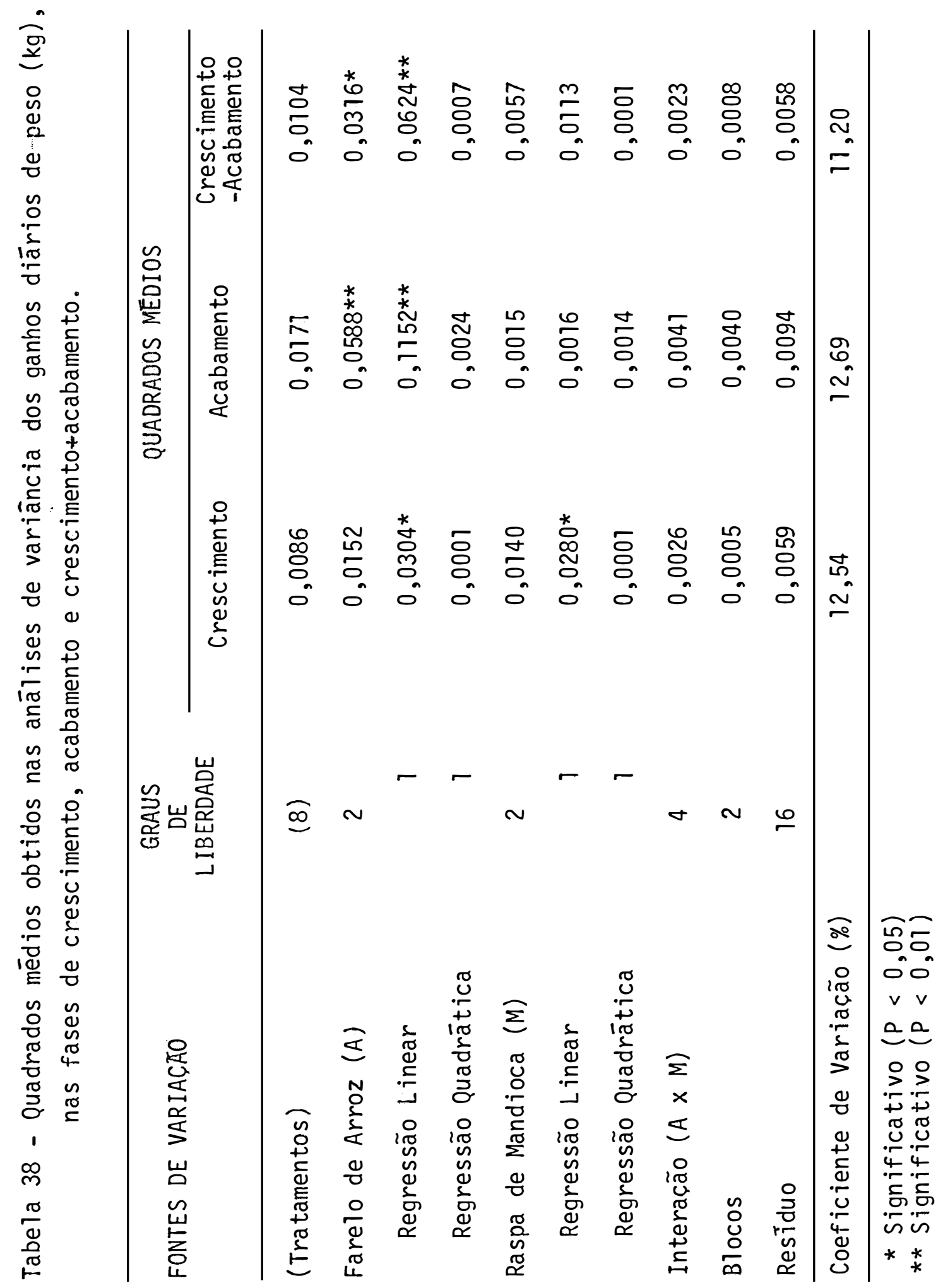


Não foi observado efeito significativo $(P>0,05)$ dos tratamentos, como também para niveis de farelo de arroz ou raspa de mandioca na fase de crescimento para ganho de peso diário. Entretanto, quando os graus de liberdade dos níveis de farelo de arroz e raspa de mandioca foram decompostos em regressão linear e quadrática, houve respostas 1 ineares negativas para os dois ingredientes ci tados. As equações de regressão linear para o farelo de arroz e raspa de mandioca foram, respectivamente,

$$
\hat{Y}=0,6541-0,0027 X
$$

e

$$
\bar{\gamma}=0,6524-0,0026 X \text {. }
$$

Essas equacões mostram que, tanto o farelo de arroz como a raspa de mandioca, responderam de maneira muito semelhante no que diz respeito ao ganho de peso diário apresentado pelos suĩnos. As referidas equacoes estão apresen tadas na Figura 9.

$\mathrm{Na}$ fase de acabamento houve efeito signifi cativo $(P<0,01)$ somente para os níveis de farelo de arroz, e tambēm resposta linear para o ganho de peso, sendo a equação obtida

$$
\nabla=0,8433-0,0053 x
$$

representada na Figura 10. 
100.

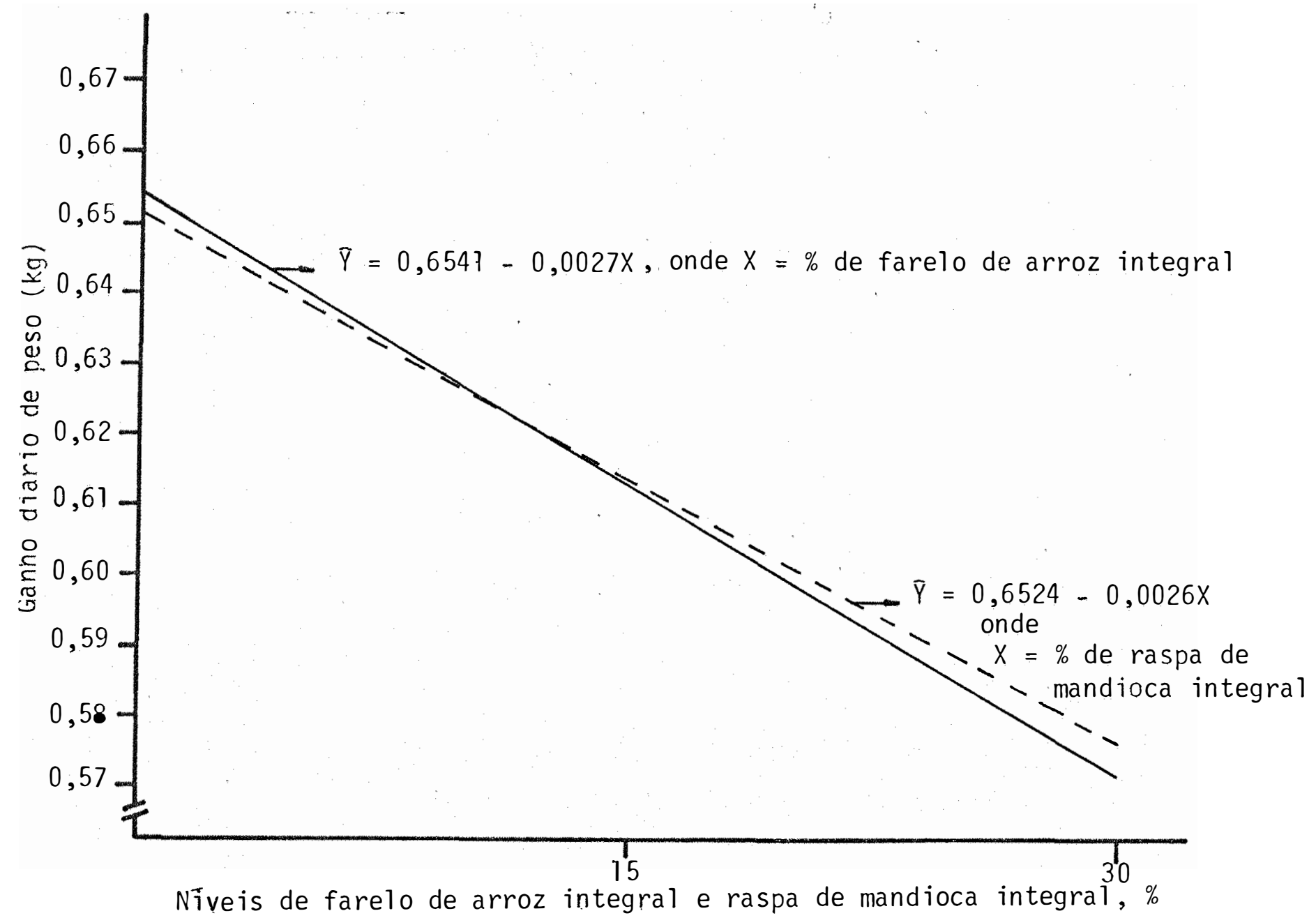

Figura 9 - Efeitos dos níveis de farelo de arroz integral e raspa de mandioca integral na ração, sobre o ganho diārio pe?os suinos, durante a fase de crescimento. 
101.

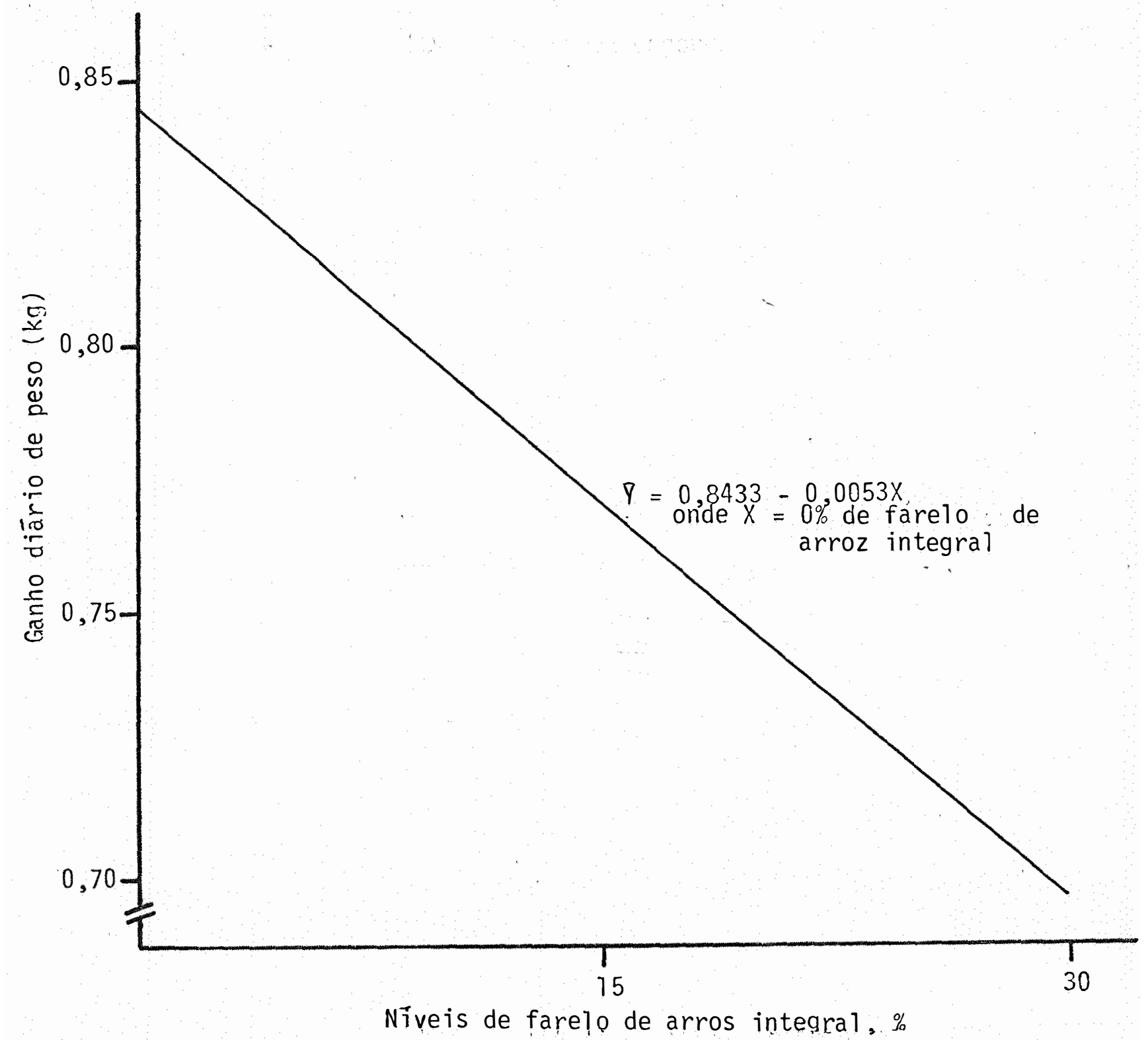

Figura 10 - Efeitos dos ñiveis de farelo de arroz integral na ração sobre o ganho diārio de peso $(\mathrm{kg})$ pelos suĩnos, durante a fase de acabamento. 
102.

As anālises de variância para ganho de peso dos suĩnos na fase de crescimento-acabamento mostraram efeito significativo $(P<0,05)$ para niveis de farelo de arroz. Com uma resposta linear negativa $(P<0,01)$. A equação de regressão linear obtida foi

$$
8=0,7707-0,0039 x \text {, }
$$

a qual estā representada na Figura 11.

Considerando a inclusão do farelo de arroz à ração, em nīveis crescentes, os resultados desse experi mento diferem dos obtidos por BRAY (1943), CUNHA (1957), VIANA (1956), NOLAND et alii (1960), MORRISON (1966), NUGARA (1966), PINHEIRO MACHADO (1967), ROJAS E BRAVO (1971) Entretanto, os resultados apresentados são= semelhantes aos observados, TRASHER et alii (1966) e SHARDA et alii (1977), os quais observaram resultados negativos para ganho de peso nos tratamentos contendo farelo de arroz.

Com relação à raspa de mandioca, os resultados são semelhantes aos observados por TORRES (1958) e PEIXOTO (1965), os quais constataram ganhos de pesos infe riores para os suỉnos alimentados com ração contendo níveis crescentes do referido ingrediente. Entretanto, re- 
103.

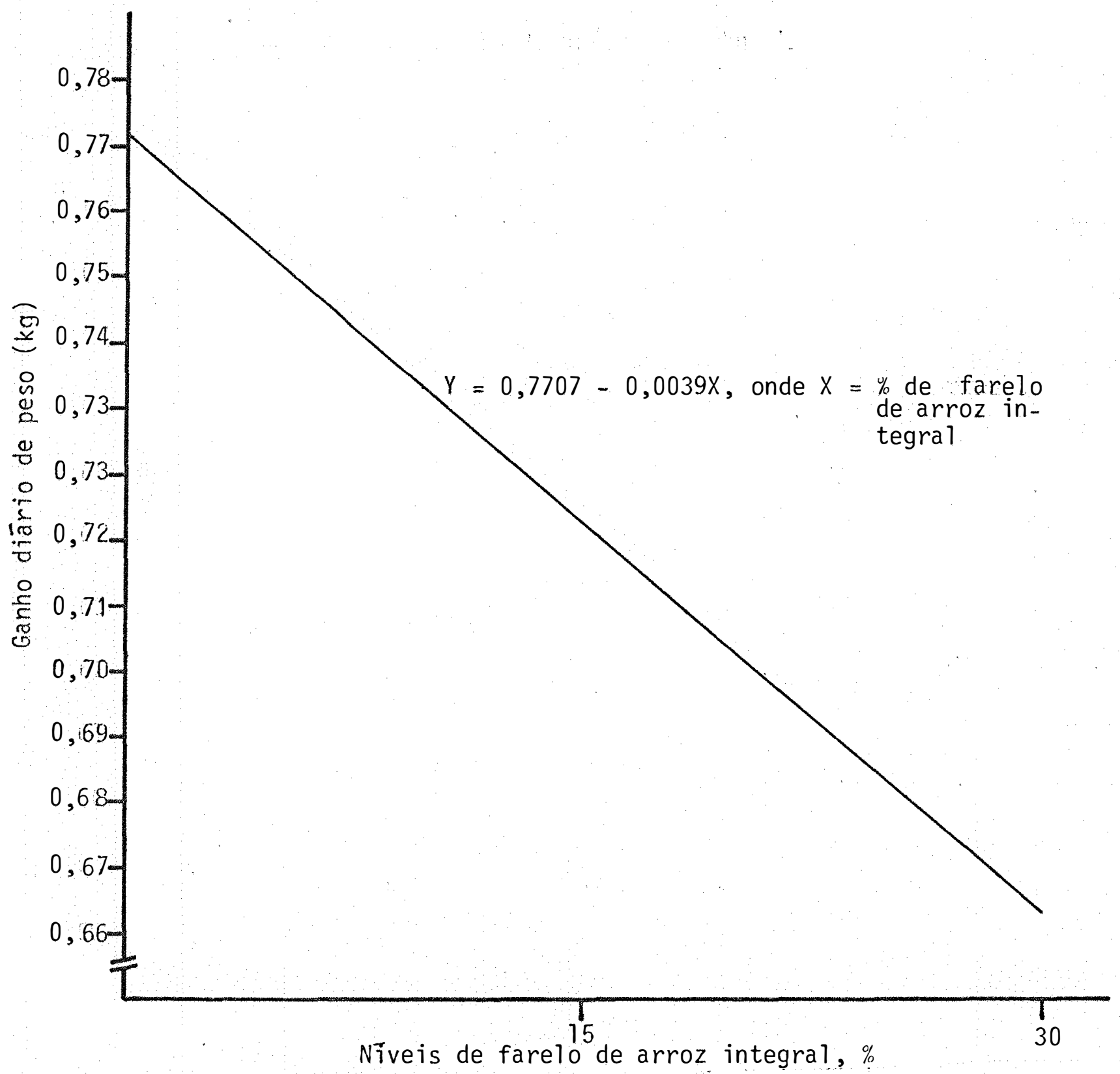

Figura 11 - Efeitos dos níveis de farelo de arroz integral na ração sobre o ganho diārio de peso $(\mathrm{kg})$ pelos suĩnos, durante a fase de crescimentotacabamento. 
sultados de ganhos de pesos positivos foram observados por MEJIA (1960), MANER et alii (1970), SHIMADA et alii(1970), PEIXOTO et alii (1973) e MULLER et alii (1974), contrarian do os resultados apresentados neste experimento.

A diminuicão dos ganhos de pesos diārios ob servados, provavelmente seja consequência do fato das racõos experimentais apresentarem altos teores de fibra, le vando a um menor consumo. Referindo-se especificamente à raspa de mandioca, os menores ganhos de peso seriam expli cáveis, segundo ALBA (1951), como decorrentes do fato de a energia metabolizável do amido da raspa de mandioca integral ser inferior à do milho (01son et alii, 1969, cita dos por heRNANDEZ e BRAMBILla, 1969). Para o farelo de arroz, a diminuição do ganho de peso poderia ser explicada atravēs do fato de que esse ingrediente apresen ta altos nîveis de ácidos graxos, levando à rancificação e, consequentemente, a um alimento pouco apetecível pelos animais. Essa explicação parece não ser vālida neste expe rimento, pois ao farelo de arroz foi adicionado um antioxidante, com o objetivo desse aditivo preservar a raça por um tempo maior. 
105.

\subsection{3 - Conversão alimentar}

A Tabela 39 apresenta as conversões alimen tares médias, durante o período experimental.

As conversões alimentares dos suĩnos nos vâ rios perīodos são mostradas na Tabela A-3, no Apēndice. Na Tabela 40 são apresentados os dados de conversões alimentares obtidos pelos suinos nas fases de crescimento, acabamento e crescimento-acabamento.

Na Figura 12 pode-se observar os histogramas de conversão alimentar dos animais submetidos aos di ferentes tratamentos.

As anālises de variância dos dados das con versões nas: fases de crescimento, acabamento e crescimento-acabamento, são apresentadas na Tabela 41.

Nas fases de crescimento e crescimento-aca bamento, as anālises de variāncia não mostraram efeito significativo $(p>0,05)$ "para conversão alimentar. Entretanto, para a fase de acabamento, a anālise de variância mostrou efeito significativo $(P<0,05)$ para $n \hat{i}-$ veis de farelo de arroz, e quando os graus de liberdade foram desdobrados em regressão linear e quadrática, houve 


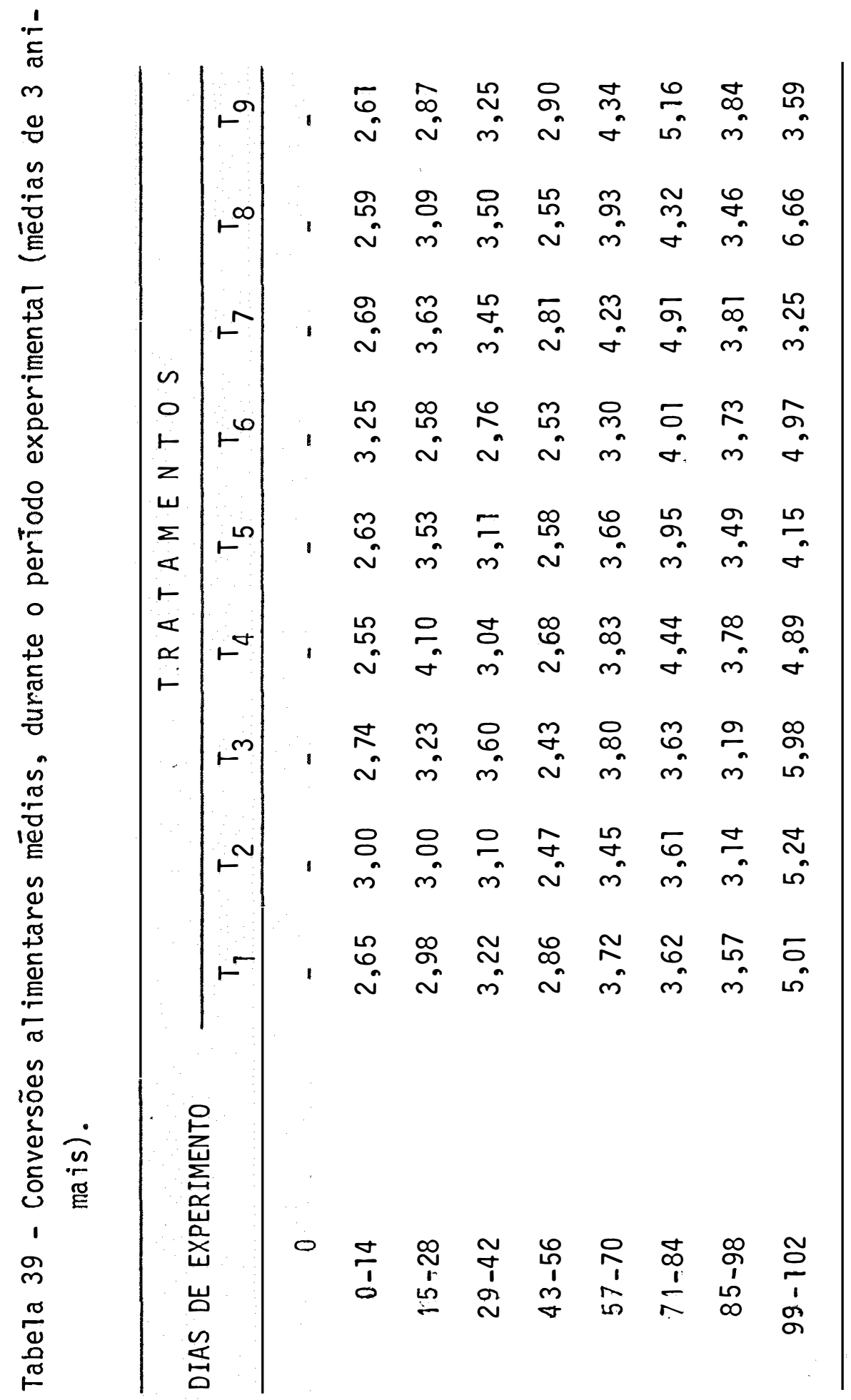


108.

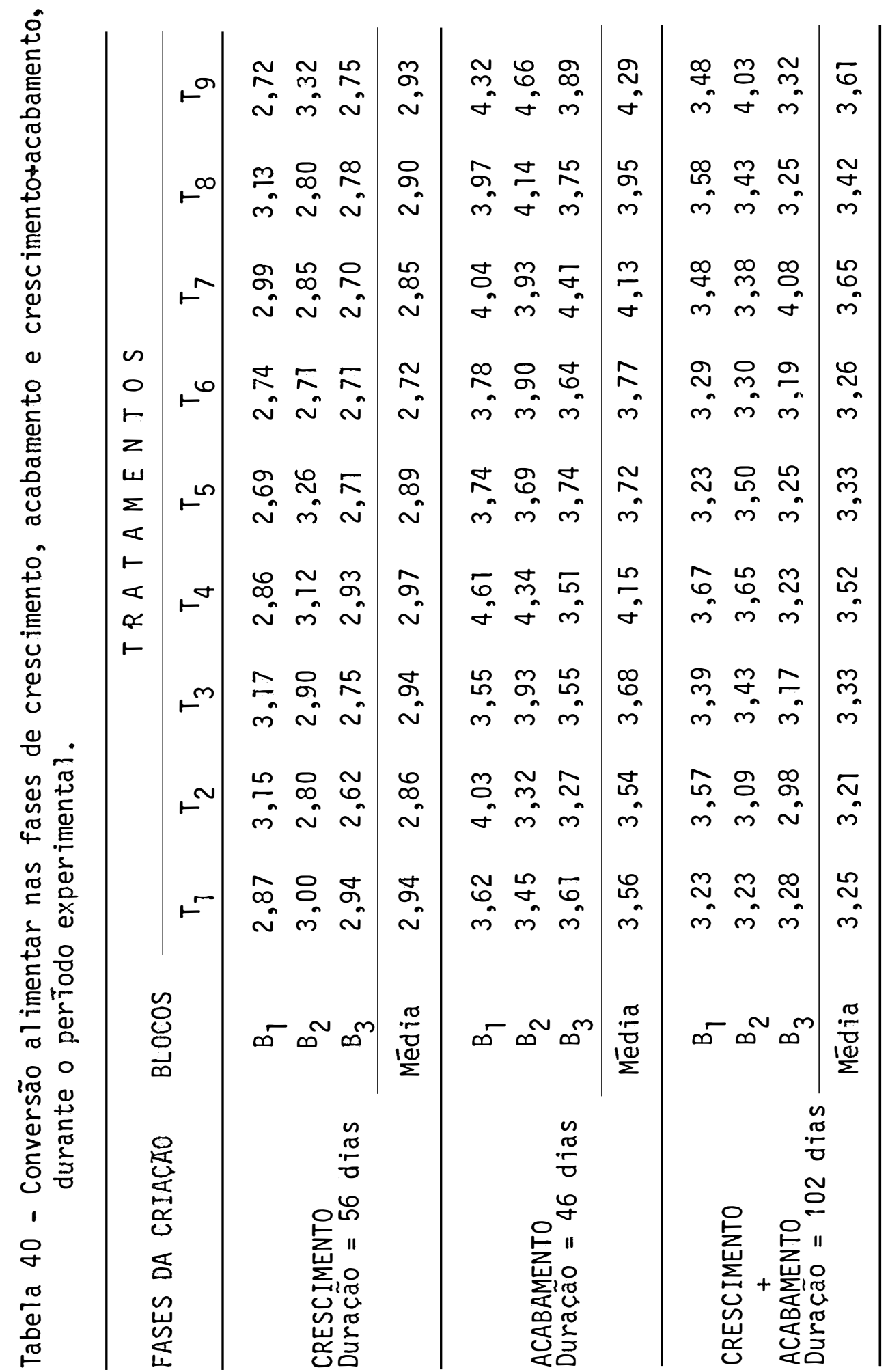




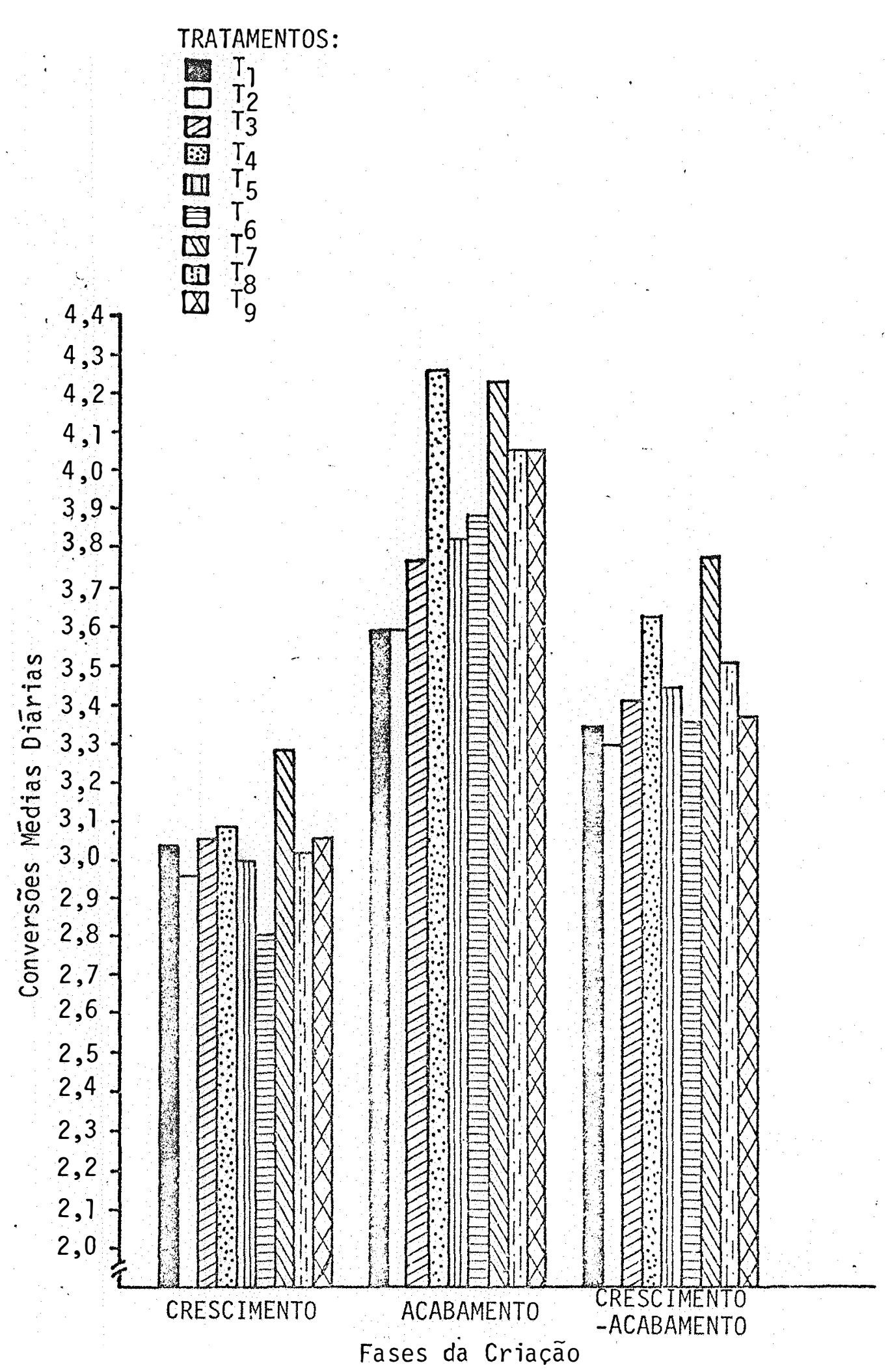

Figura 12 - Representação, atravēs de histogramas às conversões al imen tares dos suinos durante as fases de crescimento, acabamen to e crescimentotacabamento. 
109.

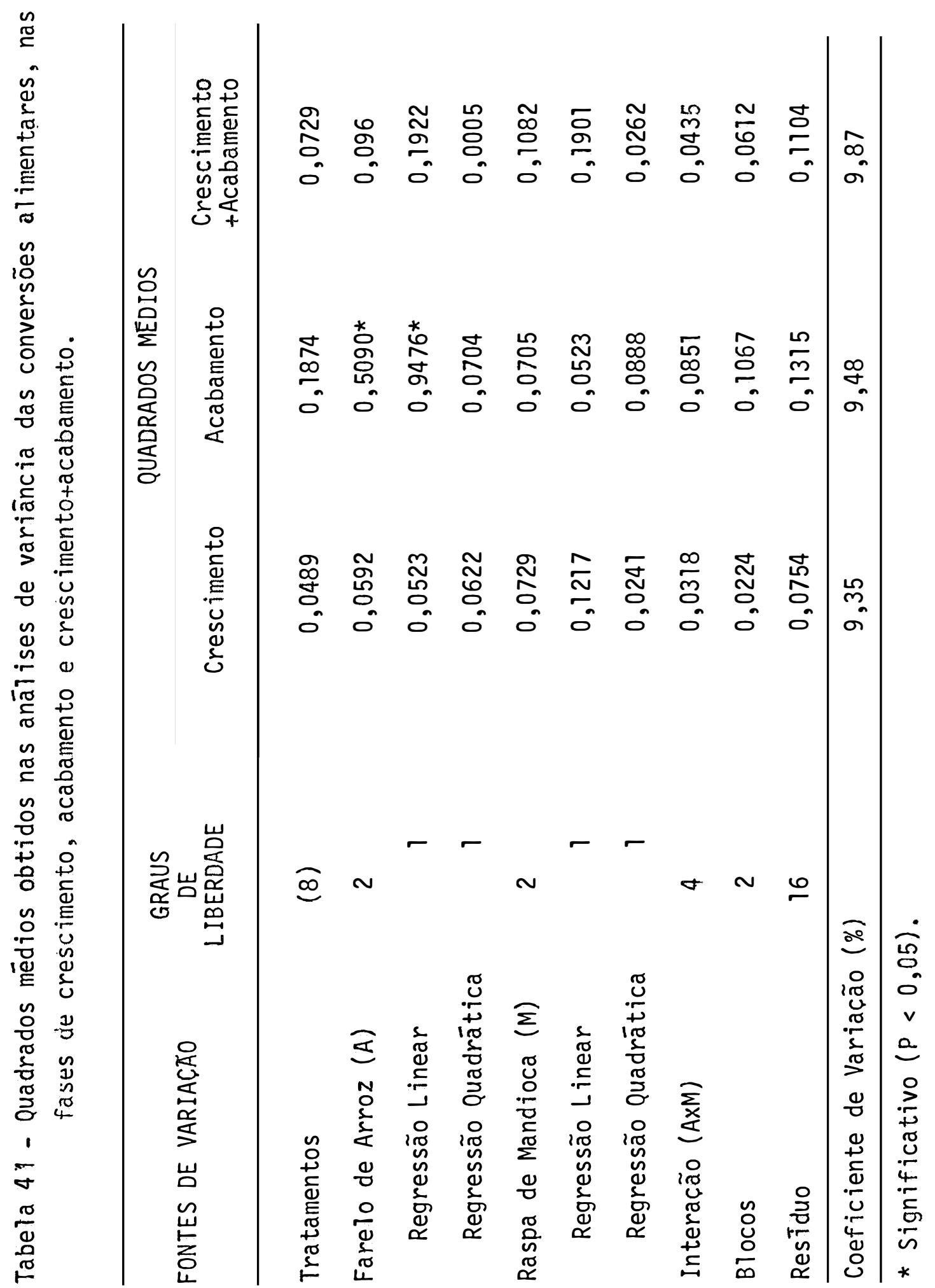


resposta linear positiva $(P<0,05)$, sendo a equação

$$
P=3,5972+0,0153 X \text {, }
$$

representada na Figura 13. Atravēs desta equação podemos observar que, para cada $1 \%$ de farelo de arroz incluído à racão, a conversão alimentar piora em 0,0153 , nesta fase.

os resultados obtidos, considerando-se a inclusão do farelo de arroz à ração, diferem com os apresentados por CUNHA (1957), DURAN (1959), NOLAND et alii (1960), COMBS (1961), MORRISON (1966), NUGARA (1966) e PI NHEIRO MACHADO (1967): Entretanto, os resultados estão de acordo com os observados por SHARDA et alii (1977), os quais observaram que nível de até $30 \%$ de farelo de arroz integral na racão, piorou a conversão alimentar.

Para a raspa de mandioca, os resultados apresentaram-se semelhantes com os de TORRES (1956/1959), VEL LOSO et alii (1965/1966), os quais não observaram efeitos prejudiciais para a conversão alimentar. Entretanto, resultados positivos para conversão al imentar foram observa dos por MEJIA (1960), SHIMADA et alii (1970), , PEIXOTO et alii(1973) e MULLER et alii (1974), diferindo dos dados observados neste experimento.

A causa da pior conversão obtida na fase de acabamento, provavelmente seja devida a a umento do teor de fibra e diminuicão do teor de energia nas rações contendo farelo de arroz integral. 
111.

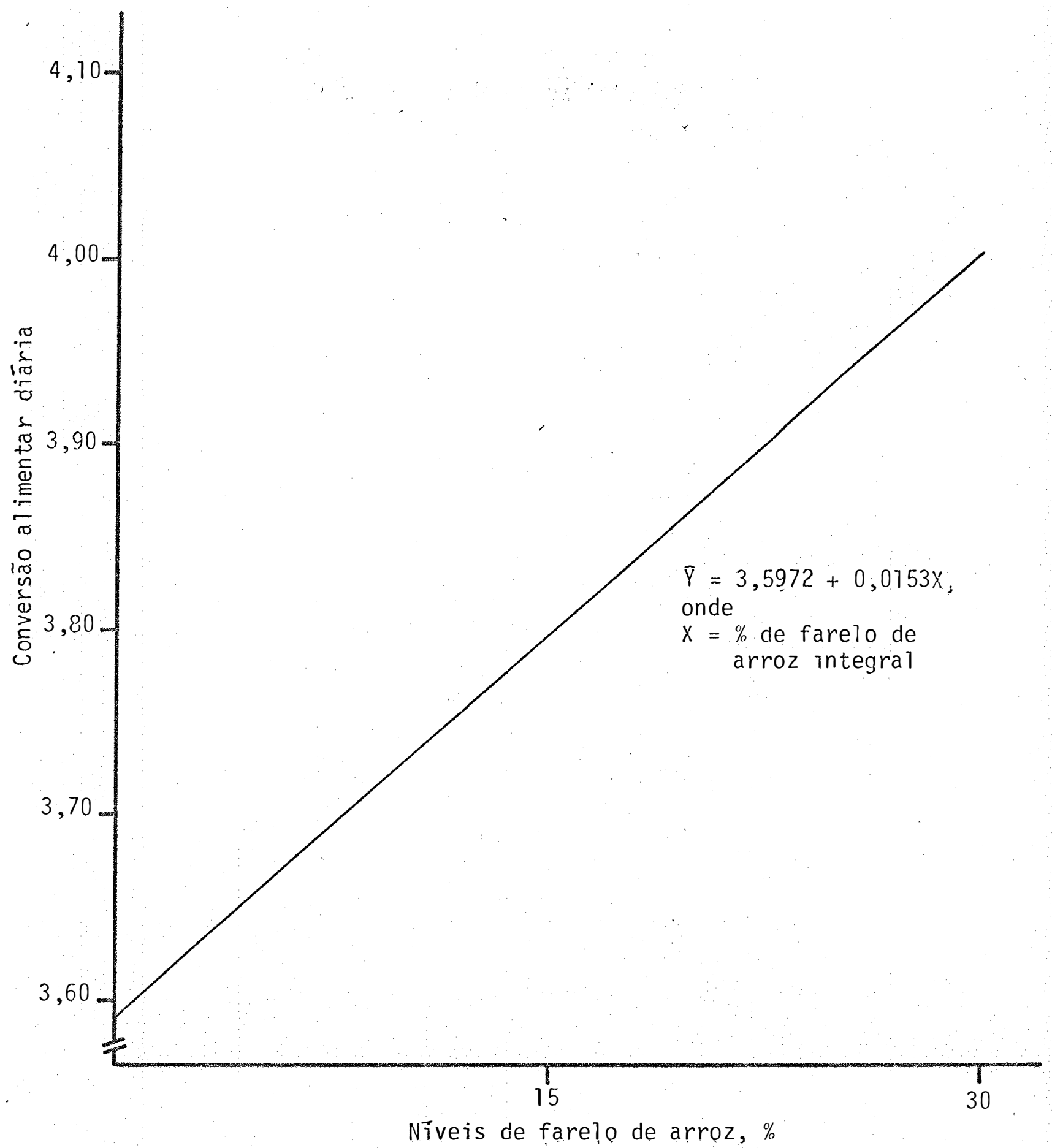

Figura 13 - Efeitos dos niveis de farelo de arroz integral na ração sobre a conversão al imentar obtida pelos suinnos, durante a fase de acabamento. 


\section{2 - Qualidade da carcaça}

Os dados obtidos na anālise das carcacas para avaliação de suas qualidades, sāo apresentados na Ta bela 4\%. As médias das características de carcaca ajustadas por covariāncia para o mesmo peso de abate $(90,25 \mathrm{~kg})$, sāo apresentadas na Tabela 43 e a Figura 14 mostra a representacão dessas características estudadas, na forma de histograma. As anālises de covariāncia de cada uma das ca racterísticas estudadas são apresentadas na Tabela 44.

os pesos de abate dos animais, bem como os valores de algumas medidas das caracteristicas de carcaca são mostrados na Tabela A-5, no Apēndice.

A anālise de covariāncia foi eficiente para remover a variabilidade do resíduo dos dados da relacão gordura:carne $(P<0,05)$. Entretanto, a anālise de co variāncia dos referidos dados, como também os de rendimen to de carcaca, porcentagem do pernil, comprimento de carcaça, nāo mostraram efeitos significativos $(P>0,05)$ para niveis de farelo de arroz e raspa de mandioca. Nem mes mo após a decomposição das somas de quadrado dos níveis de farelo de arroz, em seus componentes de regressão linear e quadrática puderam ser observados quaisquer efei- 
113.

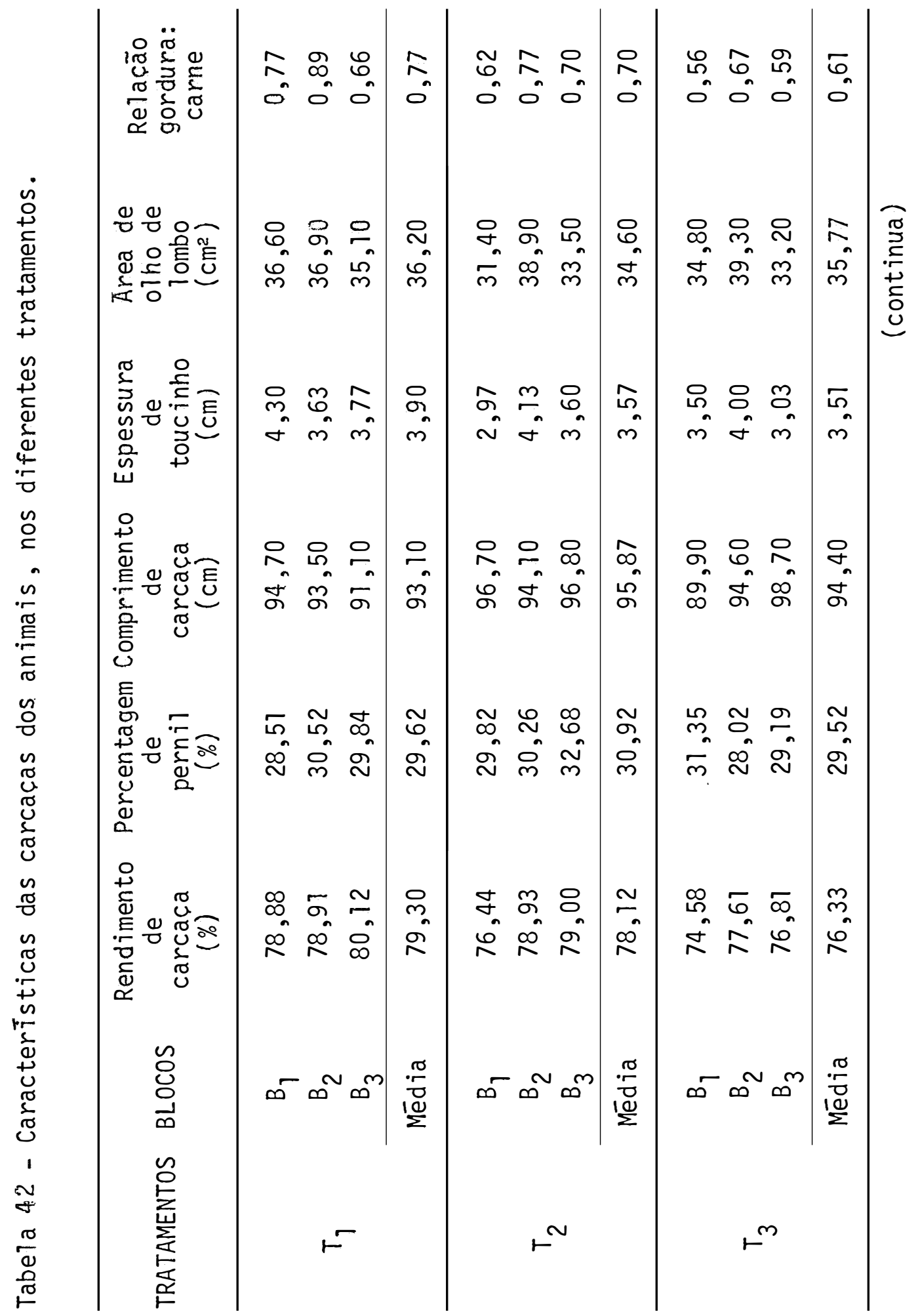


114.

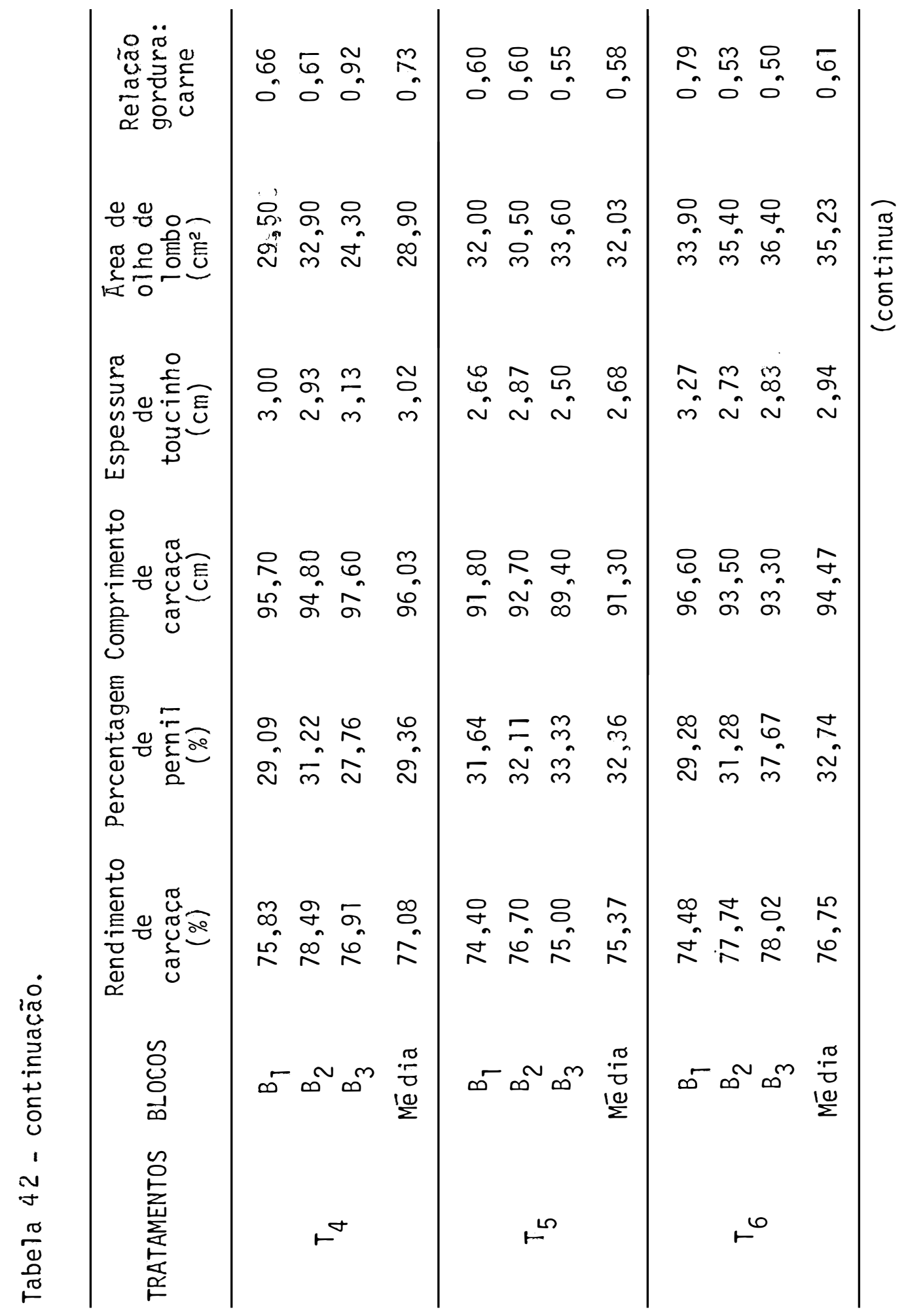




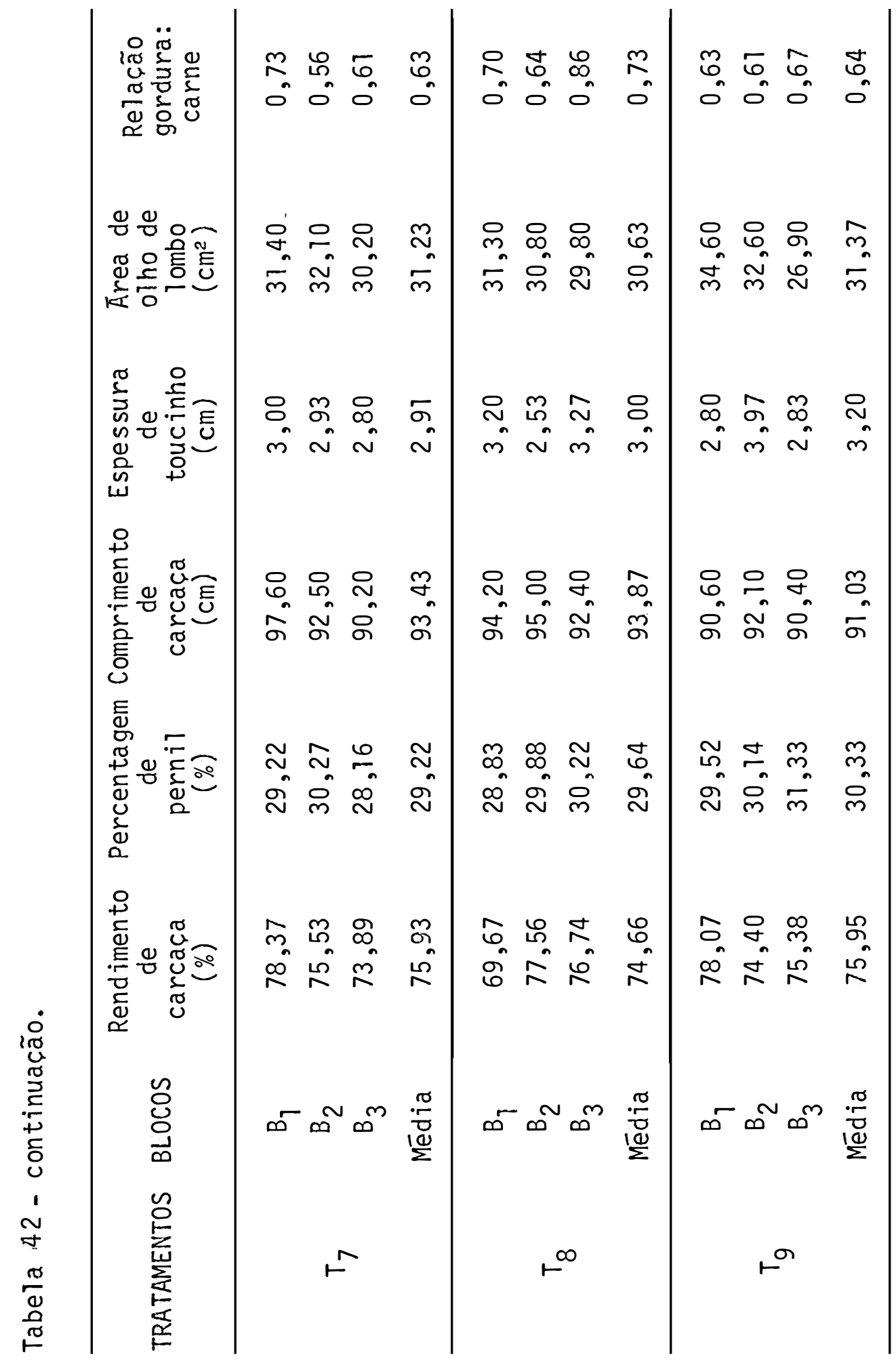


116.

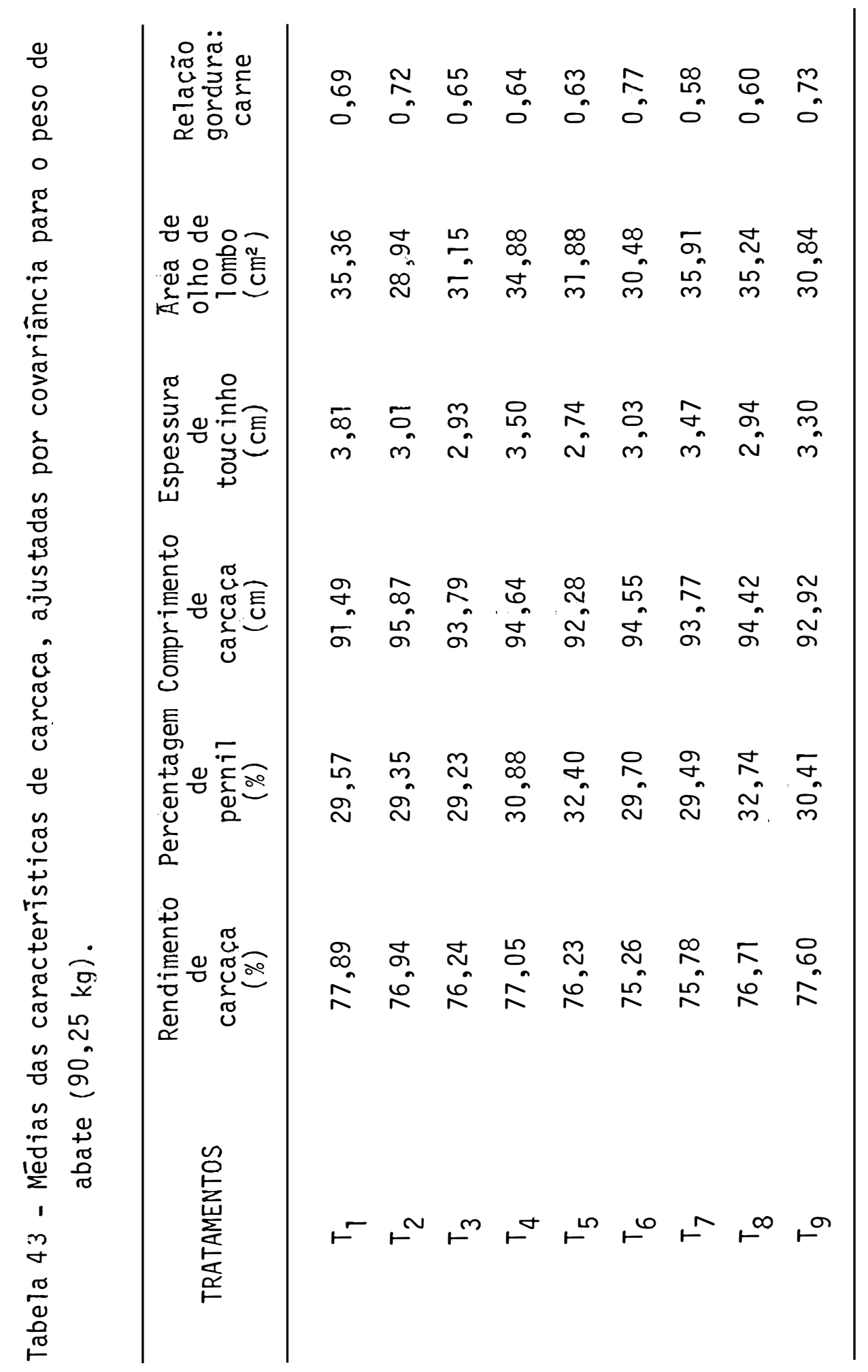




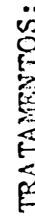
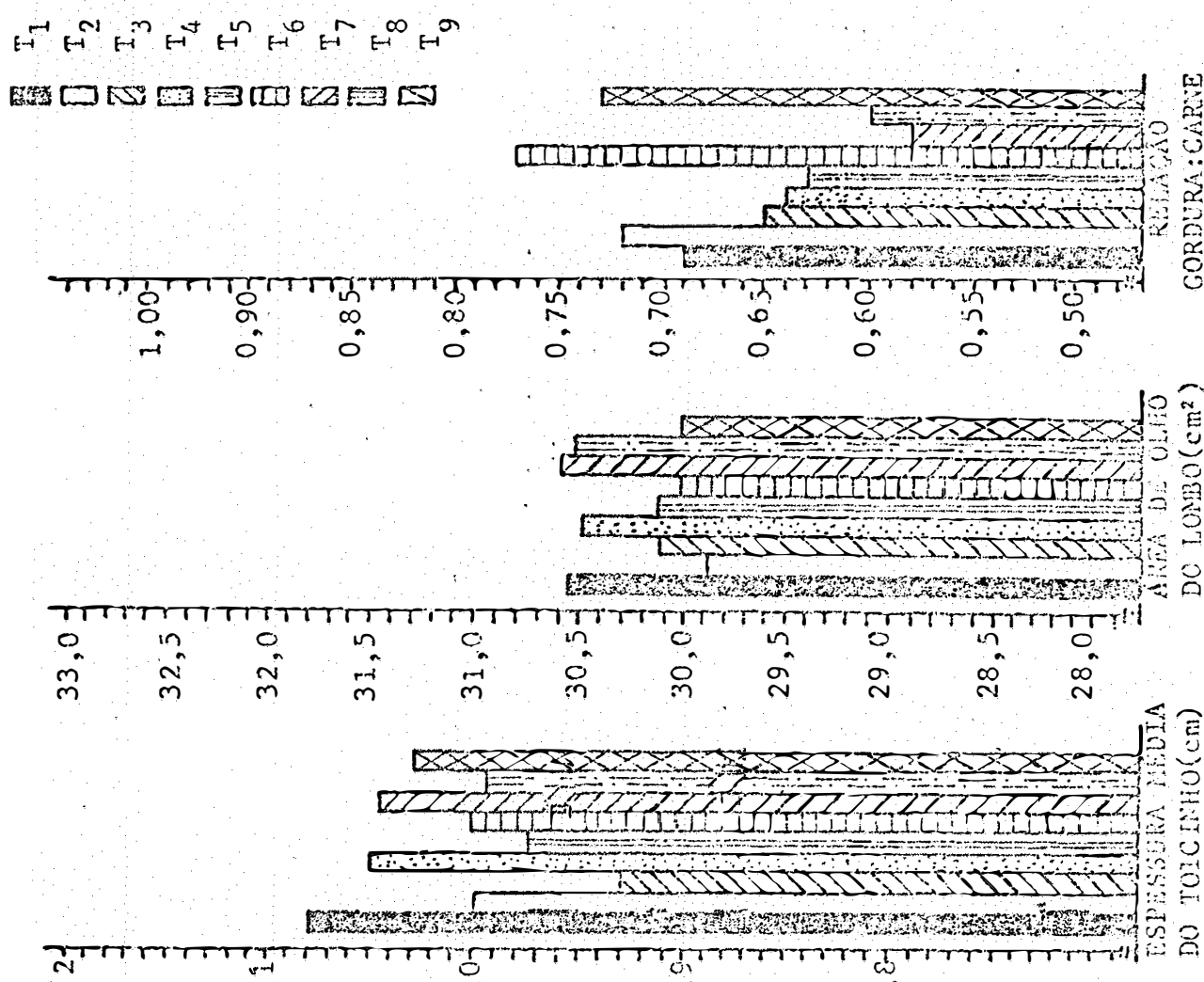

m

m

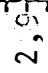

N

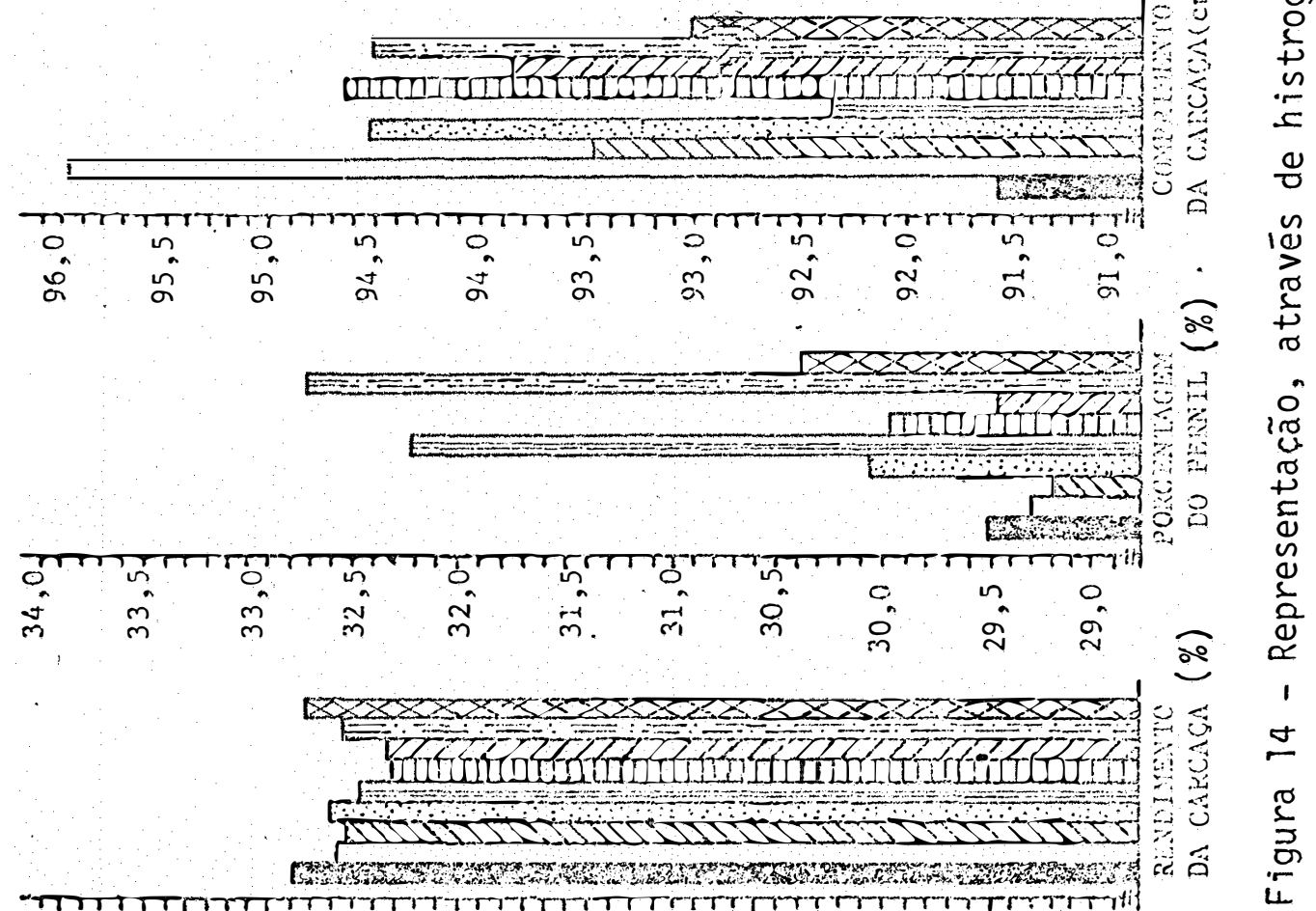

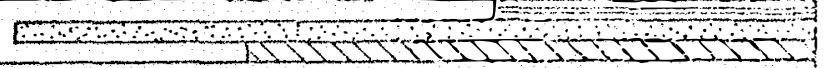

mextsing

TrTा in 0 in $0_{0}$ in 0 in o in

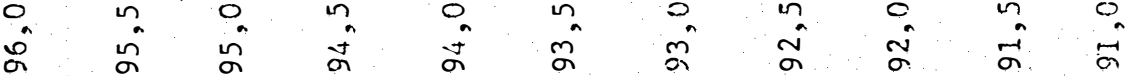

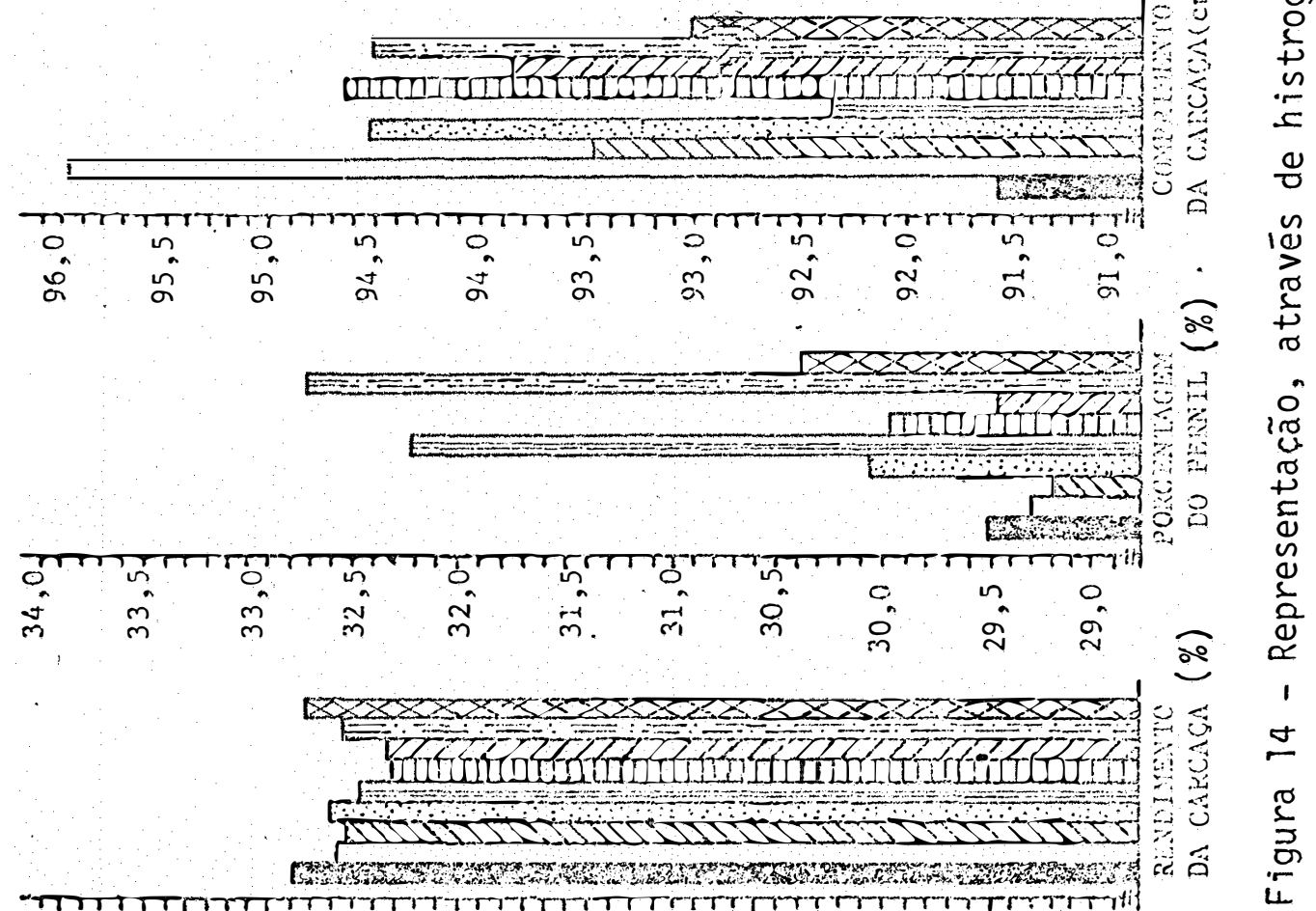

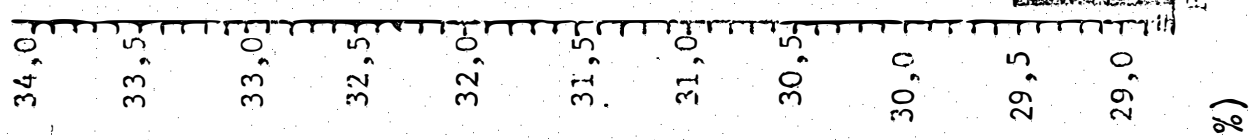

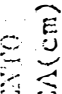

$\stackrel{\overbrace{}}{\widetilde{E}}$

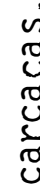

u

E

原

ธิ

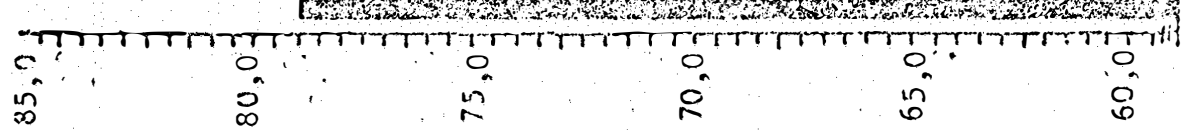


118.

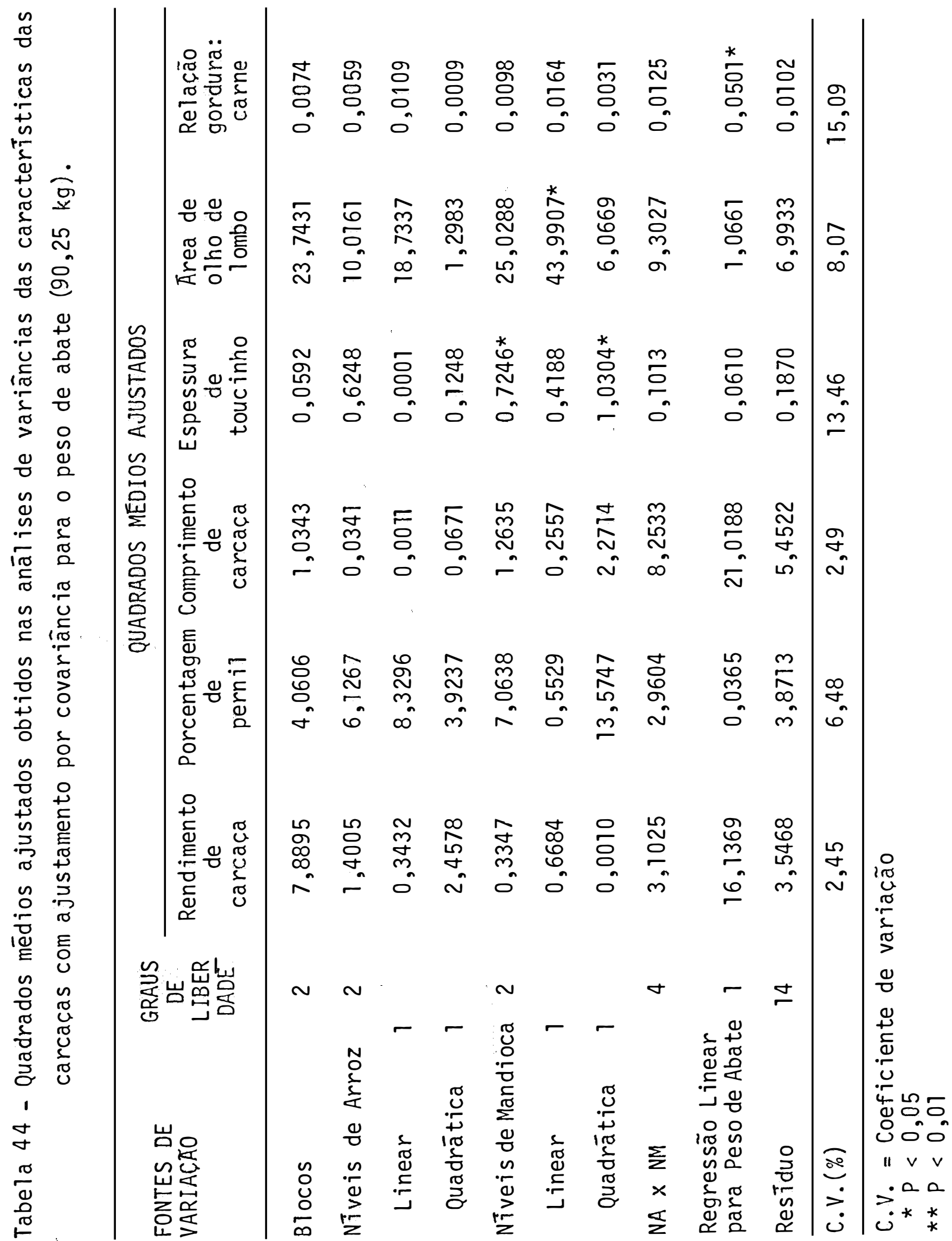


119.

tos significativos $(P>U, 05)$ dos referidos ingredientes sobre a relação gordura:carne, como também para rendimento de carcaca, porcentagem do pernil, comprimento da carcaca, espessura do toicinho e área de olho do lombo.

os resultados obtidos no presente experimento, referentes ao farelo de arroz, diferem dos obser vados por RIBEIRO (1980) o qual relatou que a área de olho do lombo, o comprimento de carcaca e a espessura de toicinho apresentaram resultados piores com a inclusão do fare10 de arroz à ração.

Entretanto, a anālise de covariância mos trou efeito significativo $(P<0,05)$ para niveis de ras pa de mandioca sobre a espessura de toicinho. Quando a soma de quadrados foi decomposta em seus componentes $1 \underline{i}$ near e quadrático, foi observada resposta quadratica, cuja equaça de regressão foi

$$
P=3,5995-0,0769 x+0,0020 x^{2},
$$

a qual esta representada na Figura 15. Para a área de olno do lombo houve resposta linear negativa, cuja equacão de 
regressāo obtida foi

$$
P=34,9180-0,1452 x
$$

representada na Figura 16.

As anālises de covariāncia nāo mostraram efeito significativo $(P>0,05)$ para rendimento de carcaca, porcentagem de pernil, comprimento de carcaca e relaçáo gordura:carne.

Os resultados obtidos neste experimento pa ra. nïveis de raspa de mandioca, e considerando a ārea de olho de lombo como característica de carcaca estudada,con cordam com as observacões obtidas por PEIXOTO (1965). Para rendimento e comprimento de carcaca os resultados apre sentados por PEIXOTO (1965), também concordam com os dados deste experimento, considerando-se que a inclusão da raspa de mandioca integral proporcionou resultados superiores quando comparados com a ração contendo milho. 
121.

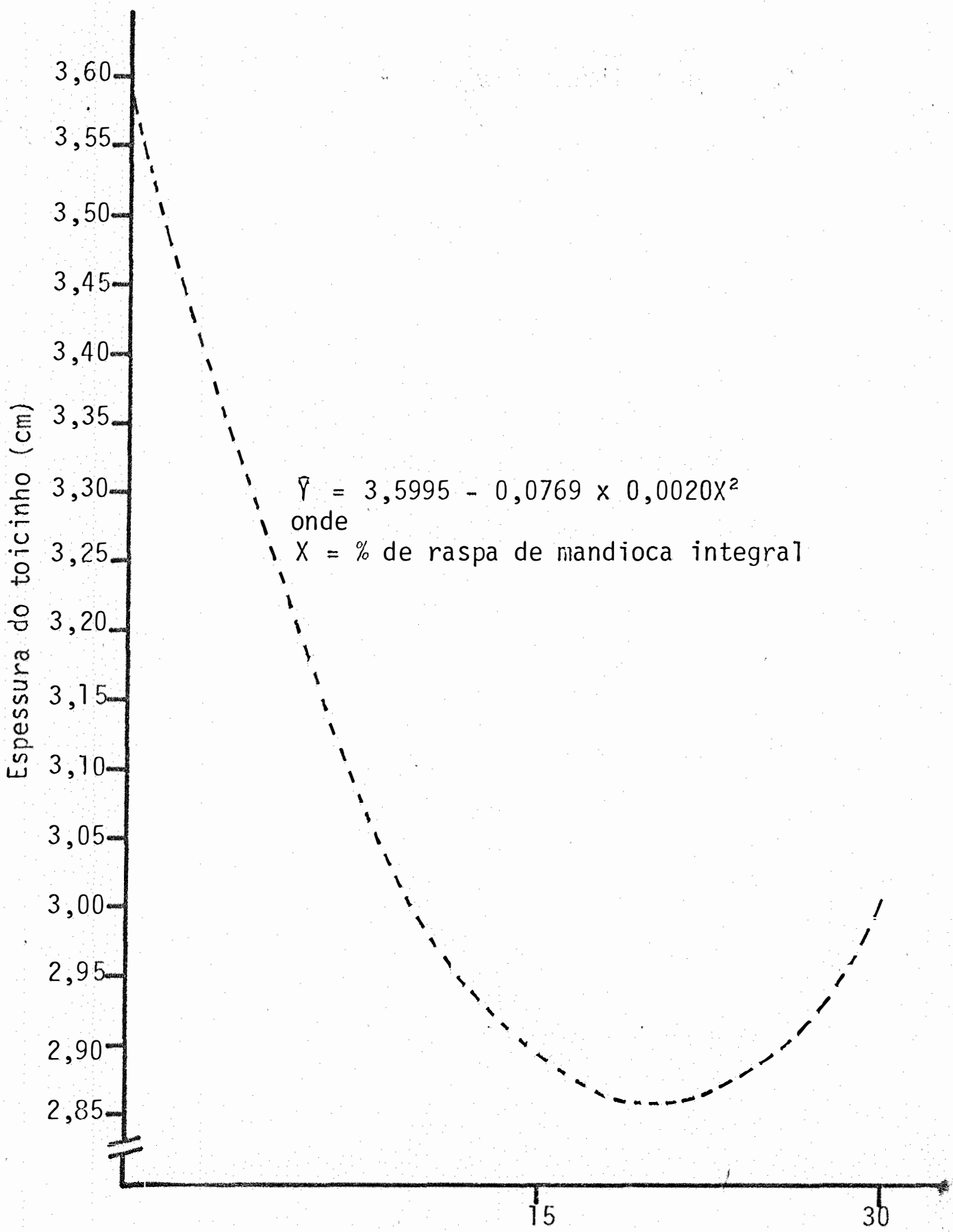

Niveis de raspa de mandioca integral, \%

Figura 15 - Efeitos dos nỉveis de raspa de mandioca integral na ração sobre a espessura de toicinho $(\mathrm{cm})$. 
122.

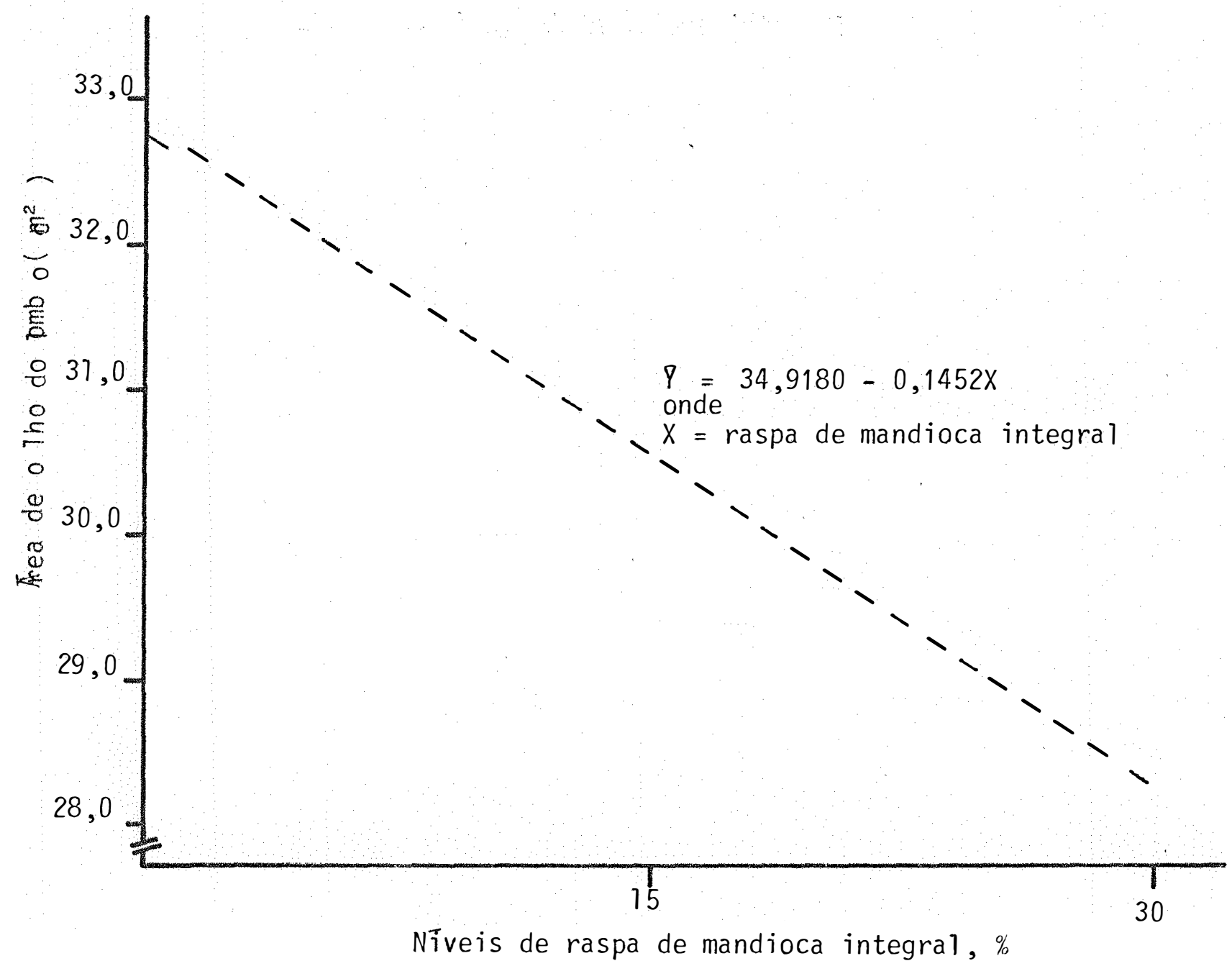

Figura 16 - Efeitos dos nīveis de raspa de mandioca integral na raçáo sobre a área de olho do 1 ombo $\left(\mathrm{cm}^{2}\right)$. 


\section{CONCLUSOES}

Considerando-se a adição do farelo de arroz integral e raspa de mandioca integral à raça e os resultados obtidos apresentados no presente trabalho, che gou-se às seguintes conclusões:

1 - Consumo de racão: na fase de crescimento e no pe rỉodo total (crescimento-acabamento), a inclusão do fare10 de arroz integral e raspa de mandioca integral proporcionou um menor consumo de ração pelos suinos. Para a fase de acabamento, somente o farelo de arroz integral reduziu 0 consumo. A diminuição do consumo nas fases em estudo, provavelmente tenha sido ocasionada pelo aumen to do teor de fibra e diminuicão da energia digestivel com a adição dos nỉveis 15 e $30 \%$ de far elo- de arroz integral ou raspa de mandioca integral às rações. 
2 - Ganho de peso: durante a fase de crescimento, a inclusão do farelo de arroz integral ou raspa de mandioca integral, levou a uma diminuicão linear do ganho de peso. Para a fase de acabamento e o periodo total (cresci mento-acabamentol somente o farelo de arroz afetou negati vamente o ganho de peso dos suinos.

3 - Conversão alimentar: na fase de crescimento e no periodo total (crescimento-acabamento), o farelo de arroz integral e a raspa de mandioca integral não causaram efeitos significativos $(P>0,05)$. Entretanto, atravēs dos dados obtidos, pode-se observar que houve uma tendencia em piorar a conversão alimentar dos suínos, com a inclusão desses dois ingredientes à ração. Considerando-se a fạ se de acabamento, a conversão alimentar piorou linearmente com os níveis crescentes do farelo de arroz à ração.

4 - Características de carcaca: os resultados mostra ram que, o rendimento de carcaça, a porcentagem de pernil, - comprimento da carcaça e relação gordura: carne, não fo ram afetados com a inclusão do farelo de arroz engordurado ou raspa de mandioca integral nas racões. Para a espes sura de toucinho, foi observado efeito quadratico com o aumento dos níveis de raspa de mandioca integral. Entretanto, para área de olho de lombo observou-se efeito linear negativo. 
os resultados do presente estudo, com a adi ç̃o ās racōes do nîvel de até $15 \%$ de farelo de arroz integral ou raspa de mandioca integral, separados ou em combinações, indicam a possibilidade de utilização dos c $\underline{i}$ tados ingredientes em racões de suínos em fases de cresci mento, acabamento e crescimento-acabamento. Apesar do nível de $30 \%$ do farelo de arroz integral ou raspa de ma $\underline{n}$ dioca integral, separados ou em combinacão quando incluídos à ração terem causado efeitos prejudiciais para alguns indices de desempenho e caracteristicas de carcaca, a utilização dos referidos ingredientes em estudo dependerá custo e disponibilidade, quando comparado com os demais alimentos que. poderão fazer parte da ração.

Novas pesquisas poderão contribuir para a determinacão dos nīveis ideais do uso do farelo de arroz engordurado e raspa de mandioca integral separadamente ou em combinações para melhores resultados económicos e de desempenho e características de carcaca. 
6. BIBLIOGRAFIA

ALBA, J., 1951. Ensayos de engorda de cerdos con raciones a base de maiz, yuca y bananas. Turrialba. Costa Rica, I(4): $176-184$.

ALBA, M.G., 1937. A study of differenct varieties of cassava for hog feeding purposes. Phillipp. Agric., 25: 782 .

ARNotT, G.W. e H.W. LIM, 1966. Animal Feeding Stuffs in Malaya. 2. Quality of rice: Bran and Polishing. The Malaycian Agricultural Journal, 45(4): 387-403.

ASIC0, P.M., 1941. A comparative study of gaplek meal and corn as basal feed for growing and fattening pigs. Phillipp. Agric. 29: 706 . 
ASSOCIAÇAOO BRASILEIRA DE CRIADORES DE SUINOS, 1973. Mētodo Brasileiro de Classificacão de Carcacas. Estrela, $16 \mathrm{p}$.

BOLHUIS, G.G., 1954. The toxicity of cassava roots. Netherlands Journal of Agricultural Science, 2: 176.

BRAGA, J.G., 1939. O uso do farelinho de arroz na alimenta cao dos animais. Revista Ceres. Vicosa, I(3): 198-216.

BRASIL, Fundação Instituto Brasileiro de Geografia e Estatîstica. 1980. Anuārio Estatīstico do Brasil. Rio de Ja neiro, I.B.G.E. $248 \mathrm{p}$.

BRASIL, Fundação Instituto Brasileiro de Geografia e Estatîstica. 1981. Anuārio Estatístico do Brasil. Rio de Ja neiro, I.B.G.E. $276 \mathrm{p}$.

BRAY, C.I., 1943. Feeding rice and rice byproducts to swine. Louisiana. (Circular, 33).

CHICCO, C.F.; J.T. PERDOMO; S.T. GARBATI; T.A. SHULTZ, 1974. Sustitución de maíz por polidura de arroz para cerdos de engorde. Revista da Agronomía Tropical. Maracay-Venezue1a, 24: 474-481.

CHICCO, C.F.; S.T. GARBATI; B. MULLER-HAYE; H. VECCHIONACCE, 1972. La harina de yuca en el engorde de cerdos. Revis ta da. Agronomía Tropica 1. Maracay-Venezuela, 12: 599-603.

COMBS, G.E., 1961. Feeds for swine: Swine Production in Florida. Florida. Depto of Agric. p. 78. (Bulletin 21). 
CORREA, F.A., 1947. Acido cianidrico em algumas variedades de mandioca. Bragantia. Campinas, $\underline{7}(1): 1-22$.

CUNHA, T.J., 1957. Swine feeding and nutrition. New York, Interscience Publishers. $269 \mathrm{p}$.

DURAN, C.A., 1959. Combinación de maíz amarillo y salvado de arroz para engorda de cerdos. Acta Agronomic. Palmi$\mathrm{ra}, \underline{9}(1 / 2): 25-33$.

FA0, 1980. Production Yearbook. Rome, Food and Agriculture Organization of the United Nations. 399 p.

FONSECA, H., 1984. Produção, Prē-Processamento e Transformação Agroindustrial: Arroz. Piracicaba, ESALQ. p. 37-169. (Sërie Extensão Agroindustrial).

GODOY, J.M., 1940. Fecularia e Amidonaria. 2ạ ed. São Pau 10. $288 \mathrm{p}$.

GOMEZ, G.G.; F. ALVARADO; J. CHAMORRO; J.H. MANER, 1978. Utilizacion de las poliduras (Polvillos) de arroz en raciones para cerdos en crescimiento y acabado. Cali-Colom bia, Centro Internacional de Agricultura Tropical (CIAT). 26 p.. (Série, E.S.).

HENKE, L.A., 1923. Feeding test with hogs. Hawaii, Hawaii Univ. p. 24 (Bulletin 6). 
HERNANDEZ, I.T.; D.S. BRAMBILLA, 1969. Investigaciones a cerca del valor nutritivo de la yuca para el pollito. Técnica Pecuäria en México. México, 12/13: 5-11.

JOHNSON, R.A. e W.D. RAYMOND, 1965. The chemical composition of some tropical food plants. IV. Manioc. Tropical Science, 7(3): 109 .

JONES, W.0., 1959. Manioc in Africa. Stanford, California, University Press.

JUAREZ GALIANO, L., 1955. Utilización de las hojas y tallos de yuca (Manihot utilissima) en la preparación de heno y concentrados para la alimentacion animal. Colom bia. Est. Exp. Agric. (Boletin 56).

JULIANO, B.0., 1972. The rice caryopsis and its composition. In: HOUSTON, D.F., (ed.) Rice-chemistry and tech. nology. St. Paul. p. 16-74.

KERR, R.W., 1950. Chemistry and Industry of Starch. 2a ed. New York. Academic Press.

KOK, E.A., 1942. O farelo de raspa de mandioca na alimentação dos animais. Boletim da Indūstria Animal. São Pau $10,5(4): 195-205$.

KOLB, E.F., 1971. Microfactores en Nutrición Animal. Madrid -Espanha, Acribia. 270 p. 
LEME JUNIOR, J., 1965. Industrialização da Mandioca. Pira cicaba, ESALn. 28 p. (Mimeo.).

LOPEZ, L. e H. HERRERA, 1970. Manihot carthagenensis. Una yuca silvestre con alto contenido proteico. In: VIII Reuniōn de Fitotecnia, Bogotá, Colombia, Noviembre, p. $22-28$.

MANER, J.H.; J. BUITAGRO; J.T. GALLO, 1970. Protein sources for supplementation of fresh cassava (Manihot sculen $t a)$ rations for growing-finishing swine. Journal of Ani mal Science. Albany, $\underline{31}(1): 208$.

MANER, J.H.; J. BUITAGRO; R. PORTELA; I. JIMENEZ, (s/d). La Yuca en Alimentacion de Cerdos. Colombia. Instituto Co1 mbiano Agropecuārio (I.C.A.) y Centro Internacional de Agricultura Tropical (CIAT). 113 p. (Mimeo.).

MAUST, L.E.; W.G. POND; M.L. SCOTT, 1972. Energy value of a cassava-rice bran diet with and without supplemental zinc for growing pigs. Journal of Animal Science. Alba ny, 35: 953-957.

MAUST, L.E.; R.G. WERNER; W.G. POND; R.E. MCDOWELL, 1969. Rice bran cassava meal as a carboydrate feed for growing pigs. Journal of Animal Science. Albany, 29(11): 140-144.

MAYMONE, B.; M. TIBERI0; A. BATTAGLINI, 1962. Dijeribilitáá e valore nutritivo dei sottoprodotti della lavorazione del riso. Ann. Sper. Agr. Roma, 16(1/2): 129-165. 
MEJIA, T.R., 1960. Valor comparativo entre la alimentacion de cerdos. Revista de la Faculdad Nacional de Agronomia. Medelin-Colombia, 20: 95-113.

MELOTTI, L.,1972. Contribuicão para o estudo da composicão quimica e valor nutritivo dos residuos na industrializacão da mandioca (Manihot utilissima, Pohl), no Estado de São Paulo. Boletim da Industria Animal, 29(2): 339-374.

MESA, J.; J.H. MANER; H. OBANDO;R. PORTELA; J.T. GALLO, 1970. Nutritive value of different tropical sources of energy. Journal of Animal Science. Albany, 31(2): 208-209.

MONDONEDO, M.; P.V. BAYON, 1927. A comparative study of corn and cassava as feeds for hogs. Philipp Agric. 15: 523 .

MORRISON, F.B., 1966. Alimentos e Alimentação dos Animais. 2ạ ed. São Paulo, Melhoramentos, 892 p.

MOURA, L.P.P.; S. NICOLAIEWSKY; E.R. PRATES; J. LODPES, 1982. Substituicão parcial e total do milho por farelo de arroz em racões para suỉnos em crescimento e terminacão. In: Anais da XIX Reunião Anual da Sociedade Brasileirade Zootecnia, Piracicaba, ESALO, p. 78-79.

MULLER, Z.; R.C. CHOU; K.C. NAH, 1974. La yuca como sustituto total de los cereales en las raciones del ganado y las aves de corral. Revista Mundial de Zootecnia. Roma-Itālia, 12: 19-24. 
NATIONAL RESEARCH COUNCIL, 1979. Nutrient Requirements of Domestic Animals: Nutrient Requirements of Swine. ed. Washington, National Research Council, 52 p.

NOLAND, P.R.; K.W. SCOTT; A.W. NORTH, 1960. Rice bran can be used growing-finishing swine. Arkansas Farm Research. Arkansas, $9(5): 9-12$.

NOLAND, P.R.; K.W. SCOTT, 1963. Effect of varying protein and energy intakes on growth and carcass quality swine. Journal of Animal Science... Albany; 19(1): 67-70.

NORMANHA, E.S.; A.S. PEREIRA, 1950. Aspectos agronōmicos de cultura da mandioca (Manihot utilissima Poh1). Bragantia. Campinas, 10(7): 179-202.

NUGARA, D.S.; 1966. The use of rice bran in pig rations. Ceylon Veterinary Journal. Cobombo, 14(1/2): 15-17.

OKE, 0.L., 1969. The role of hydrocyanic acid in nutrition. World Review of Nutrition and Dietetics, 11:170.

PACHECO, C.R.V.M., 1979. Uso de Aditivos. In: Anais do Simpósio sobre Suinocultura, Piracicaba, ESALQ, $254 \mathrm{p}$.

PEIXOTO, A.R., 1963. Mandioca. Rio de Janeiro. Servico de Informaçöes Agricolas. 96 p. [Produtos Rurais, 5].

PEIXOTO, R.R., 1965. Estudo comparativo entre farinha de mandioca e milho, como alimentos para porcos em crescimento e engorda. Pelotas. Escola de Agronomia Elizeu Maciel. 19p, [Boletim Técnico]. 
PEIXOTO, R.R.; J.V.S. FARIAS, 1973. Estudo da : influēncia da prensagem (pellets) em racões com elevado teor de man dioca para porcos em crescimento e terminacão. In:Anais da X Reunião da Sociedade Brasileira de Zootecnia, Fortaieza, p. 241-242.

PEIXOTO, R.R.; J.V.S. FARIAS, 1974. Estudo da influência da prensagem ("pellets") de ração com elevado teor de farinha de mandioca no desempenho e caracteristicas da carcaca de porcos em crescimento e terminacao. In: Anais da XI Reunião da Sociedade Brasileira de Zootecnia. Fortaleza, p. 163-164.

PEIXOTO, R.R.; J.V.S. FARIAS, 1975. Adição de $3 \%$ de öleo à raça com $55 \%$ de farinha de mandioca para porcos em crescimento e terminação. In: Anais da XII keunião da Sociedade Brasileira de Zootecnia, Brasilia. p. 104.

PEIXOTO, R.R. e N. ISLABAO, 1969. Substituição do milho ao nível de $50 \%$ de farinha de mandioca na alimentação de suînos em engorda. Pelotas. Escola de Agronomia Elizeu Maciel. 17 p. [Boletim Técnico].

PINEDA, J.; L. ARA; A.A. OWEN; J. BUITAGRO, 1975. Determi nación del valor nutritivo y del nivel optimo de utilización de la harina de arroz en dietas para cerdos. Revista del Instituto Colombiano Agropecuārio. Bogotá-cólombia, 10(1): 127-137.

PINHEIRO MACHADO, L.C., 1967. Os Suínos. Porto Alegre, Editora A Granja. $632 \mathrm{p}$. 
RIEIRO, U.F.F., 1980. O farelo de arroz na alimentação de suinos. Suinocultura Industrial, Gessulli. Editores Ltda. Ribeirão Preto, 24:12-14.

ROJAS, L.M.; F.C. BRAVO, 1971. Efecto de la sustituciōn progresiva de maiz com poliduras de arroz como alimento para el cerdo. Técnica Pecuäria en México. México, 15/19: $9-12$.

ROSTAGNO, H.S.; D.J. SILVA; P.M.A. COSTA; J.B. FONSECA; P.R. SOARES; S.A.A. PEREIRA; M.A. SILVA, 1983. Composição de alimentos e exigēncias nutricionais de aves e suinos. Vicosa, 59 p. [Tabelas Brasileiras].

SANTANA, J.C.R.; P.M. COSIA; H.V. MELLO;A.B.SANSEVERO; L. C. MENEZ, 1978. Raspa de mandioca processada pelo calor seco (torragem) na alimentacão de suínos. Revista Brasileira de Zootecnia. Vicosa, $\underline{7}(1): 53-78$.

SĂo PAULO. Instituto de Economia Agrícola, 1979. Prognóstico 79/80. São Paulo. 278 p.

SATO PAULU. Instituto de Economia Agrícola, 1983. Prognōstico 83/84. São Pau1o, 12(1): 241 .

SHARDA, D.P.; K. PRADHAN; P. SINGH, 1977. Nutritive value of rice polish. Journal of Animal Science. Albany, 47 $(8): 482-485$.

SIMOES, R.H., 1978. Arroz. Anuārio Agroveterinārio, p. 2$-10$. 
SHIMADA, A.S.; C. PERAZA; F.T. CABELO, 1970. Valor alimen ticio de la harina de yuca para cerdos. Técnica pecuäria en Mëxico. México, (15/17): 31-35.

SREERAMANURTHY, V.V., 1945. Investigations on the nutriti ve value of tapioca (Manihot utilissima). Indran J.Med. Res. $33: 229$.

TORRES, A.P., 1949. Alimentação das Aves. 2ạ ed. São Pau10, Melhoramentos, $32 \mathrm{p}$.

TORRES, J.R., 1956/59. Associacão da raspa de mandioca e milho desintegrado no crescimento-engorda de suinos. Revista Ceres. Vicosa, 10: 392-401.

TORRES, J.R., 1958. Associação do farelinno remoido de trigo e milho desintegrado nas racões de suinos em cres cimento e engorda. Revista Ceres. Vicosa, 10(59): 346-357 .

TRASHER, D.M.; A.M. MULLINS; V.B. SCOTT, 1966. Reevaluation of rice bran in modern pig rations. Journal of Animal Science. Albany, 25: 258.

TRINDADE, D.S.; J. LOPES; S.C. OLIVEIRA; I.M. DEXHEIMER; A.C.L. CAVAlHeIRo, 1974. Substituicão parcial do milho pelo sorgo e pela farinha de mandioca em racoes para frangos de corte. Kevista da Sociedade Brasileira de Zootecnia. Vicosa, $\underline{3}(1):$ 13-29. 
VELLos0, K.P., 1y62. Oleo de farelo de arroz. Lavoura Arrozeira. Porto Alegre, $2(3): 16-18$.

VELLOSO, L.; A.J. ROURIGUES; M. BECHER; L.P. NETO; W.N. SCOTT; E.B. KALIL; L. MELOTTI; G.L. ROCHA, 1965/66. Sub tituicão parcial e total do milho pelo farelo de mandioca em raçoes de suinos em crescimento e engorda. Boletim da Indūstria Animal. São Paulo, 23: 129-137.

VIANA, A.T., 1956. Os Suĩnos, Criação Prātica e Econōmica. 2ạ ed. Rio de Janeiro, Serviço de Informação Agrícola do Ministério da Agricultura. 348 p.

VOGT, H., 1966. The use of tapioca meal in poultry rations. World's Poultry Science. 22: 113.

WOODMAN, H.E.; A.W. MANZIESKITCHIN; R.E. EVANS, 1931. The value of tapioca flour and sago pith meal in the nutrition of swine. Journal of Agriculture Science, 21: 526.

ZOBY, J.L.F., 1967. Kaspa de mandioca suplementada com gor dura e metionina na alimentação de suĩnos. Viçosa. Imprensa Universitária, 45 p. [Dissertação de Mestrado]. 
137.

7. A P ENDICE 


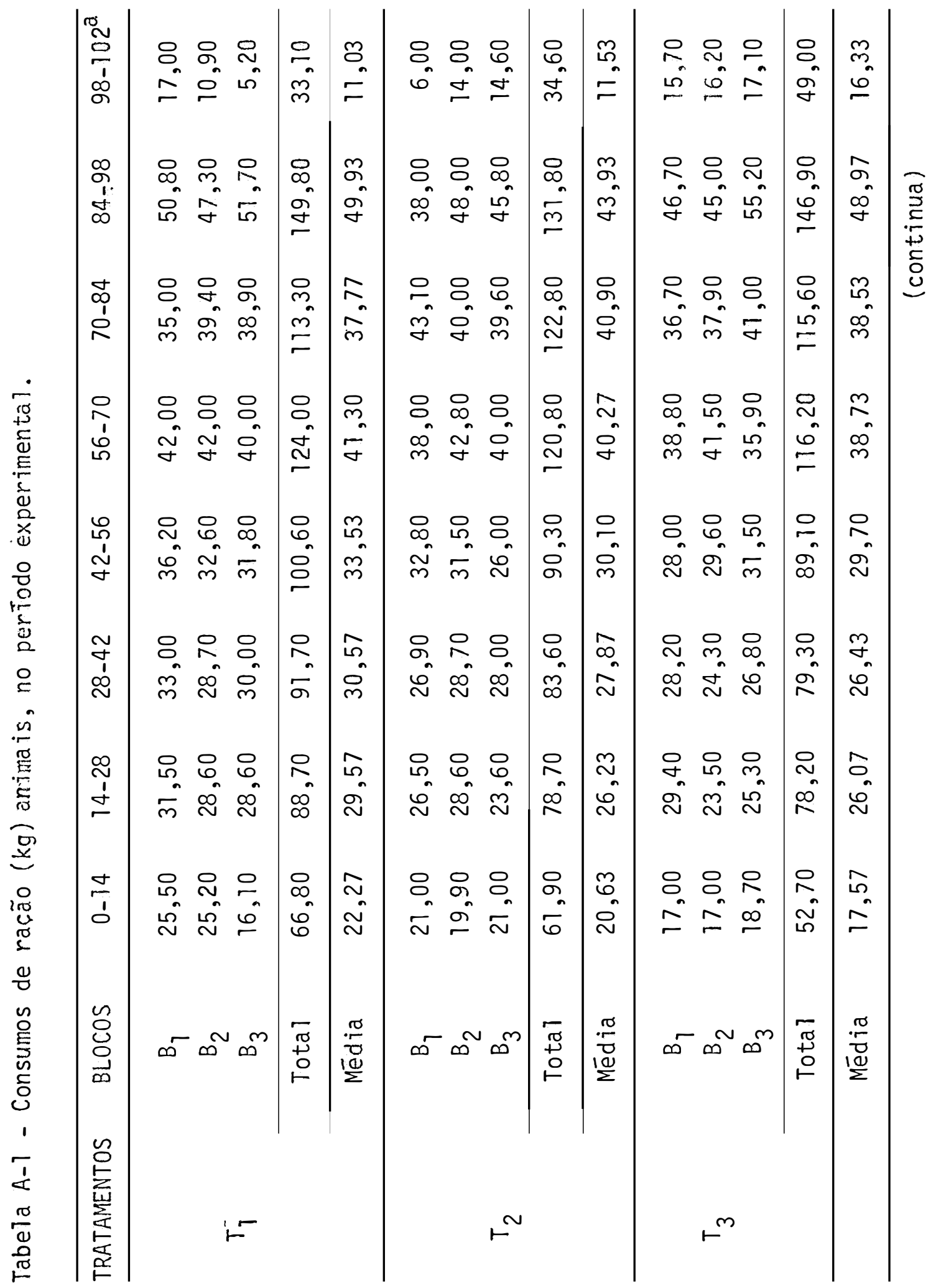




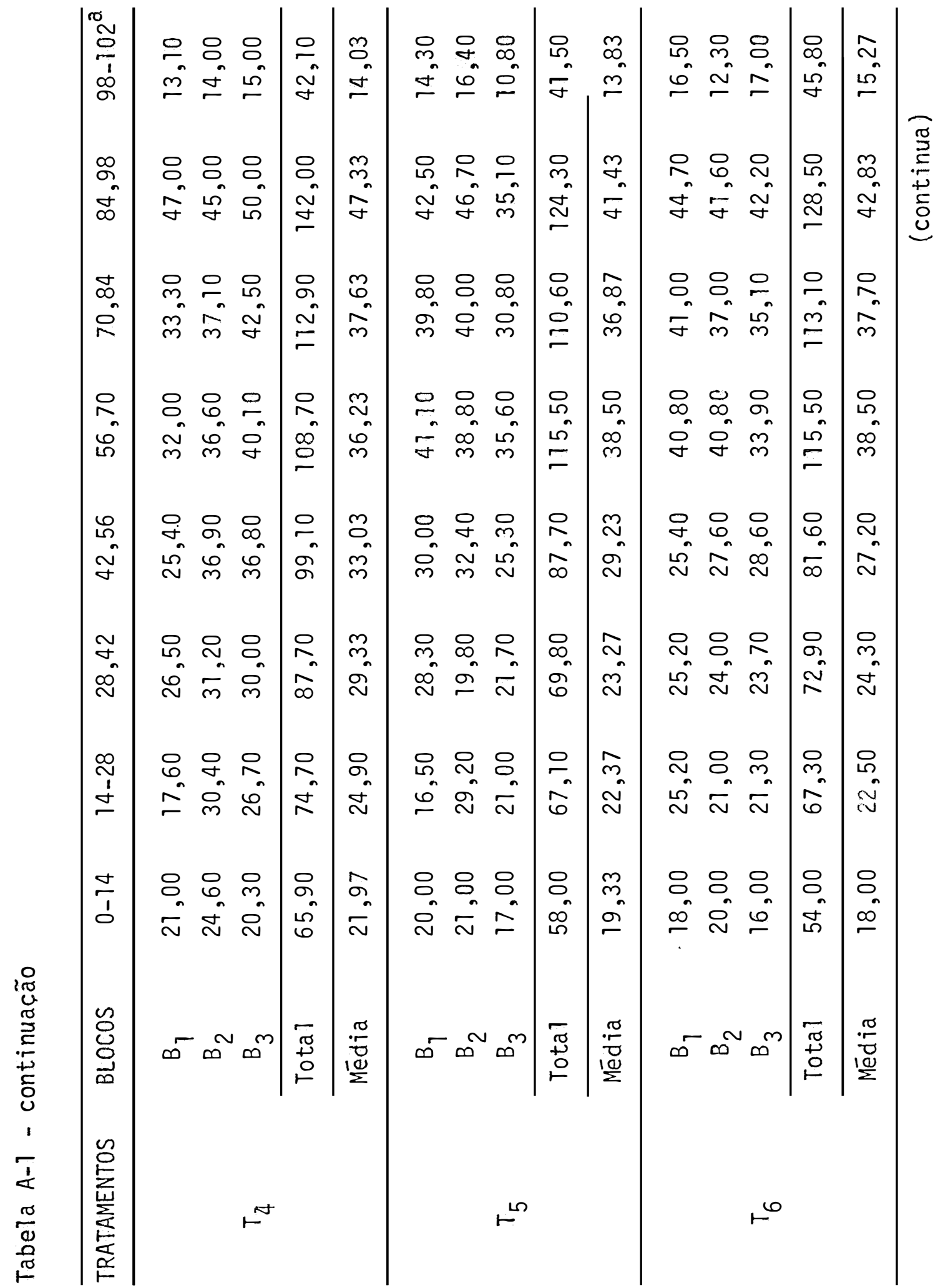


140.

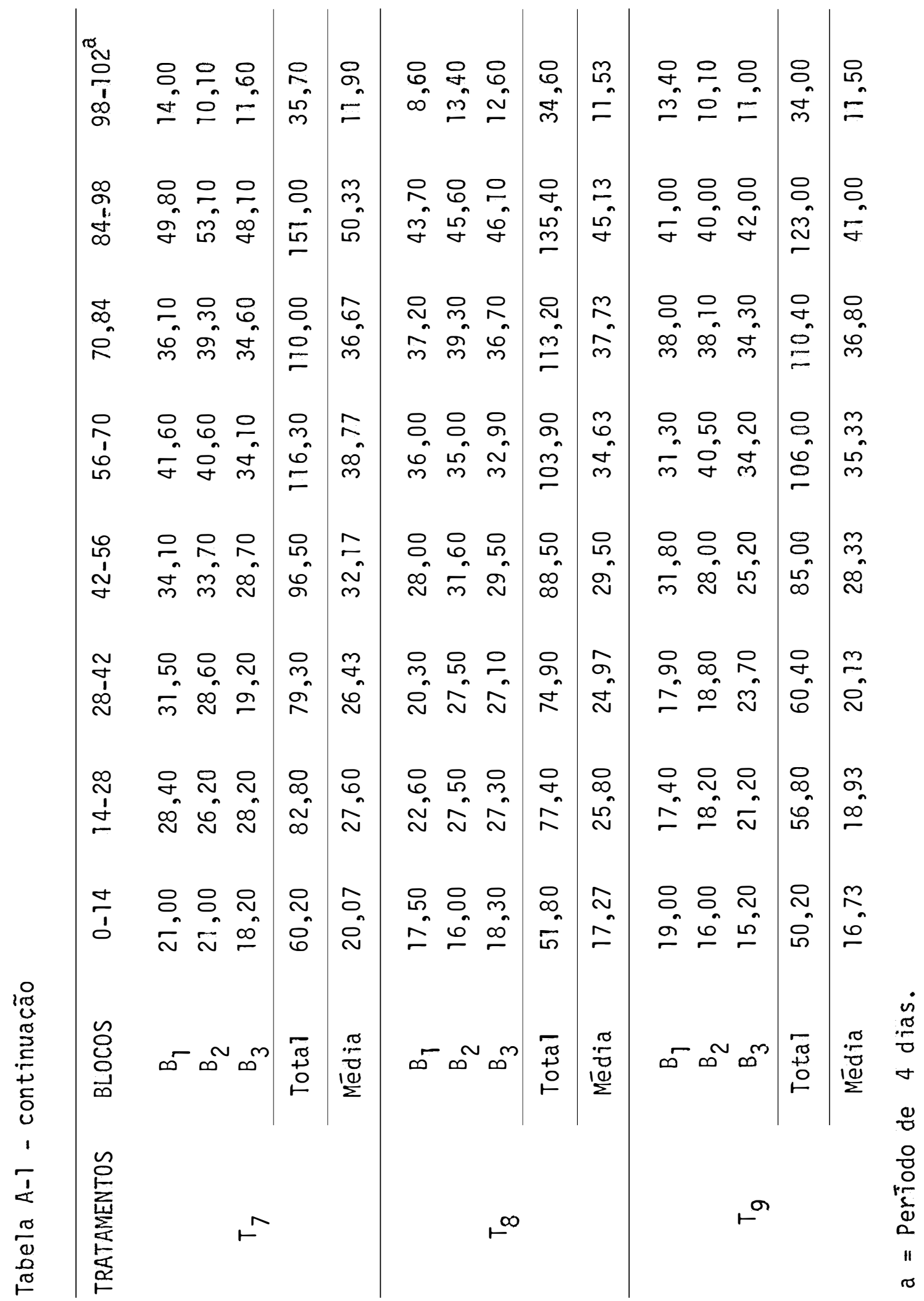




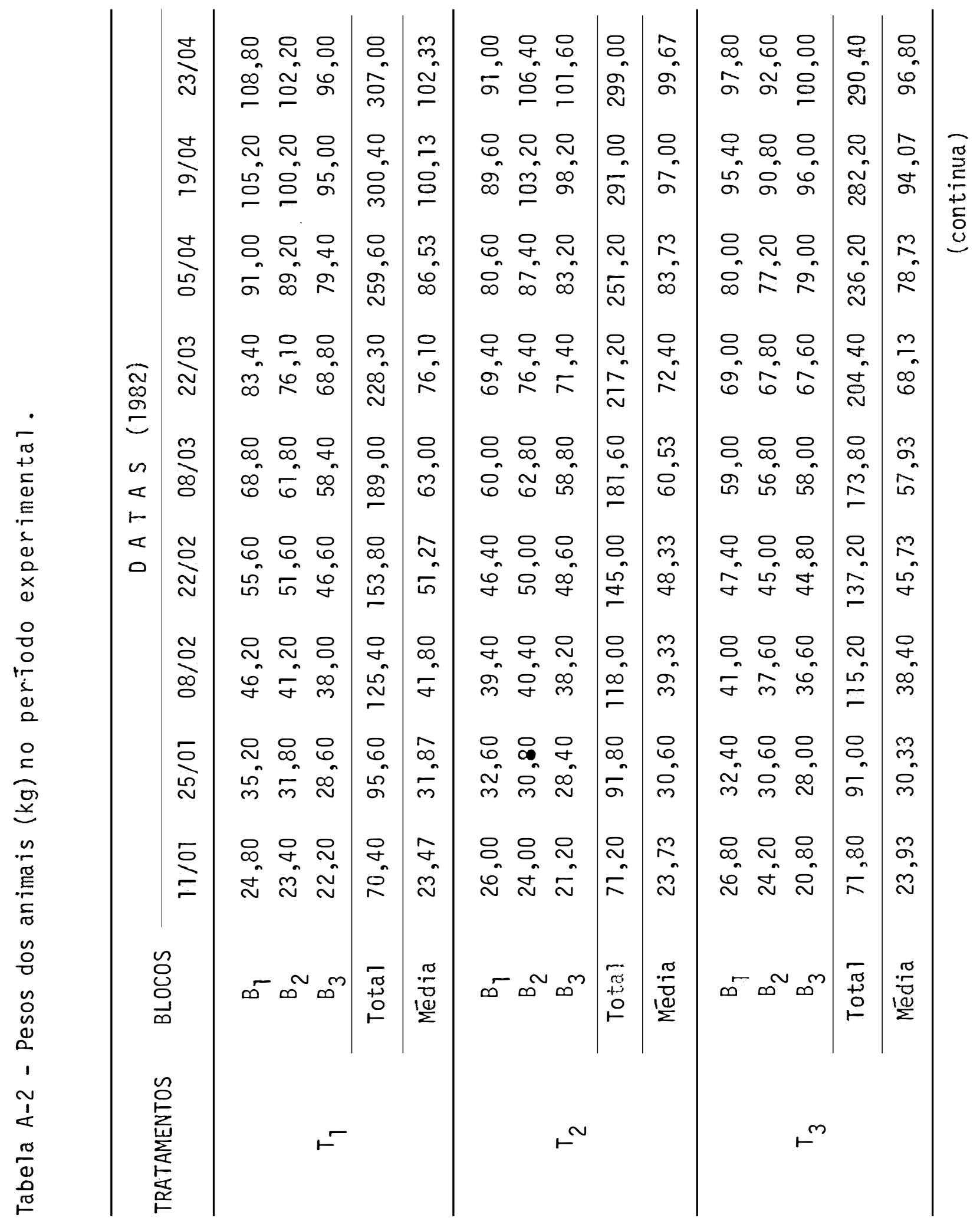




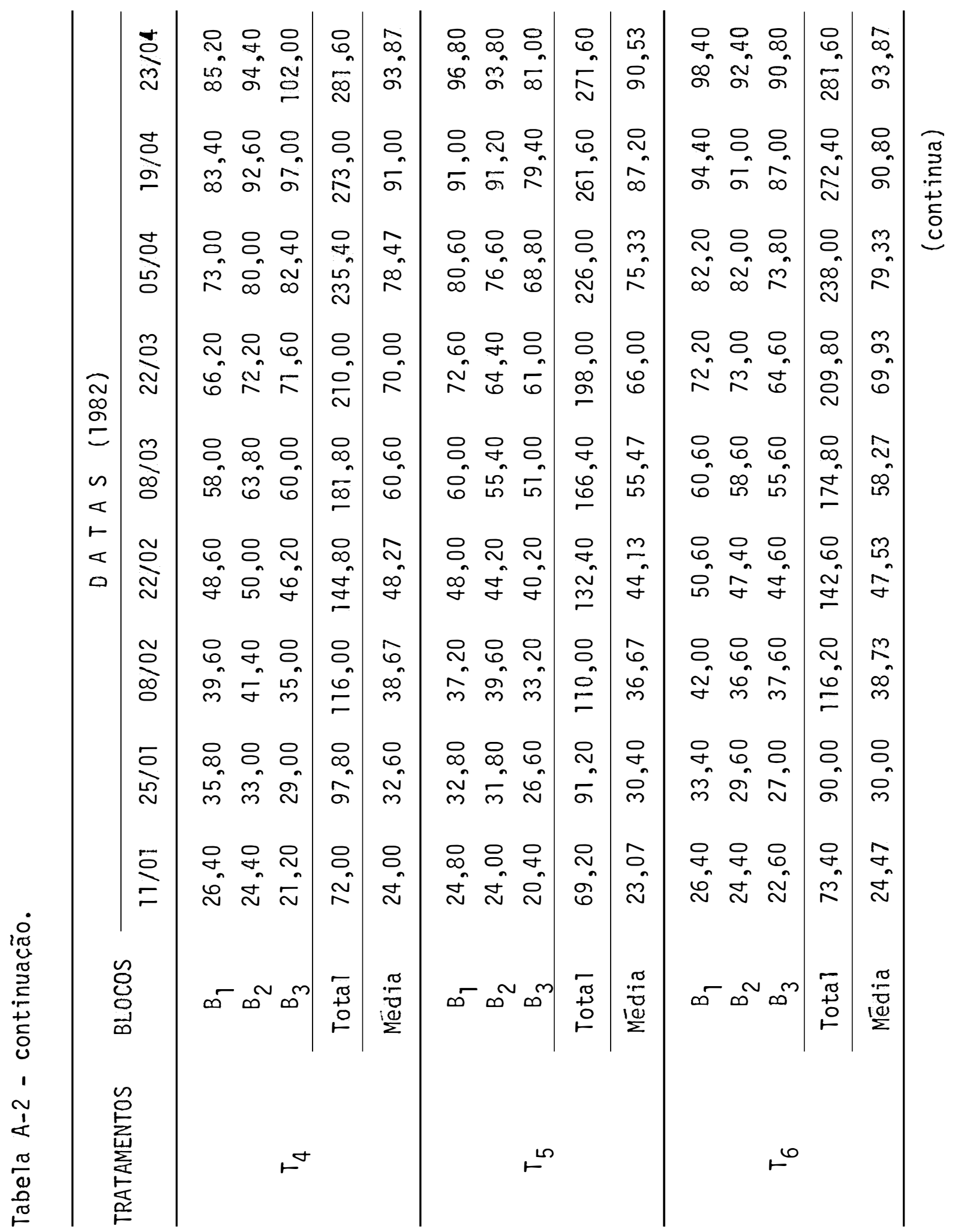




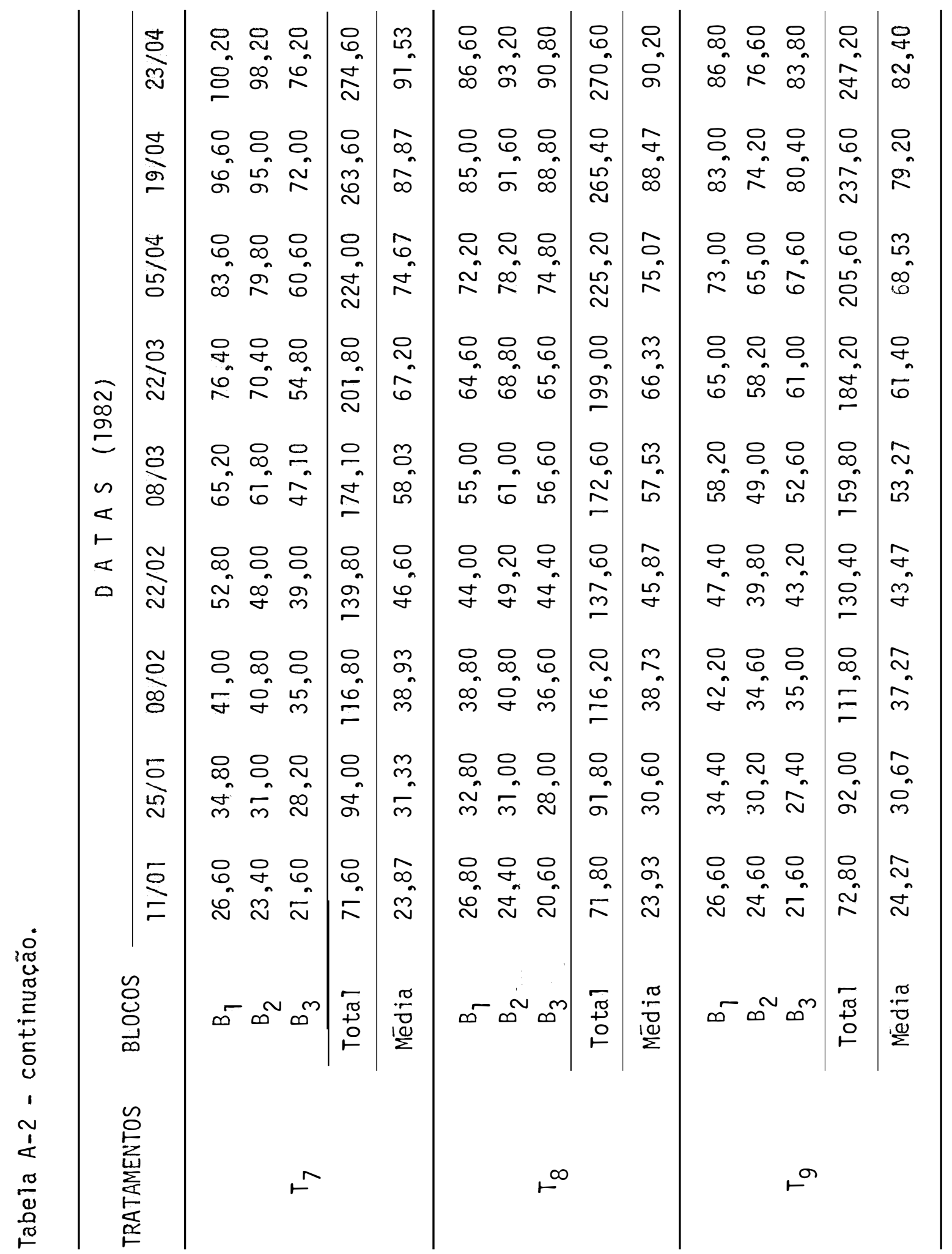


144.

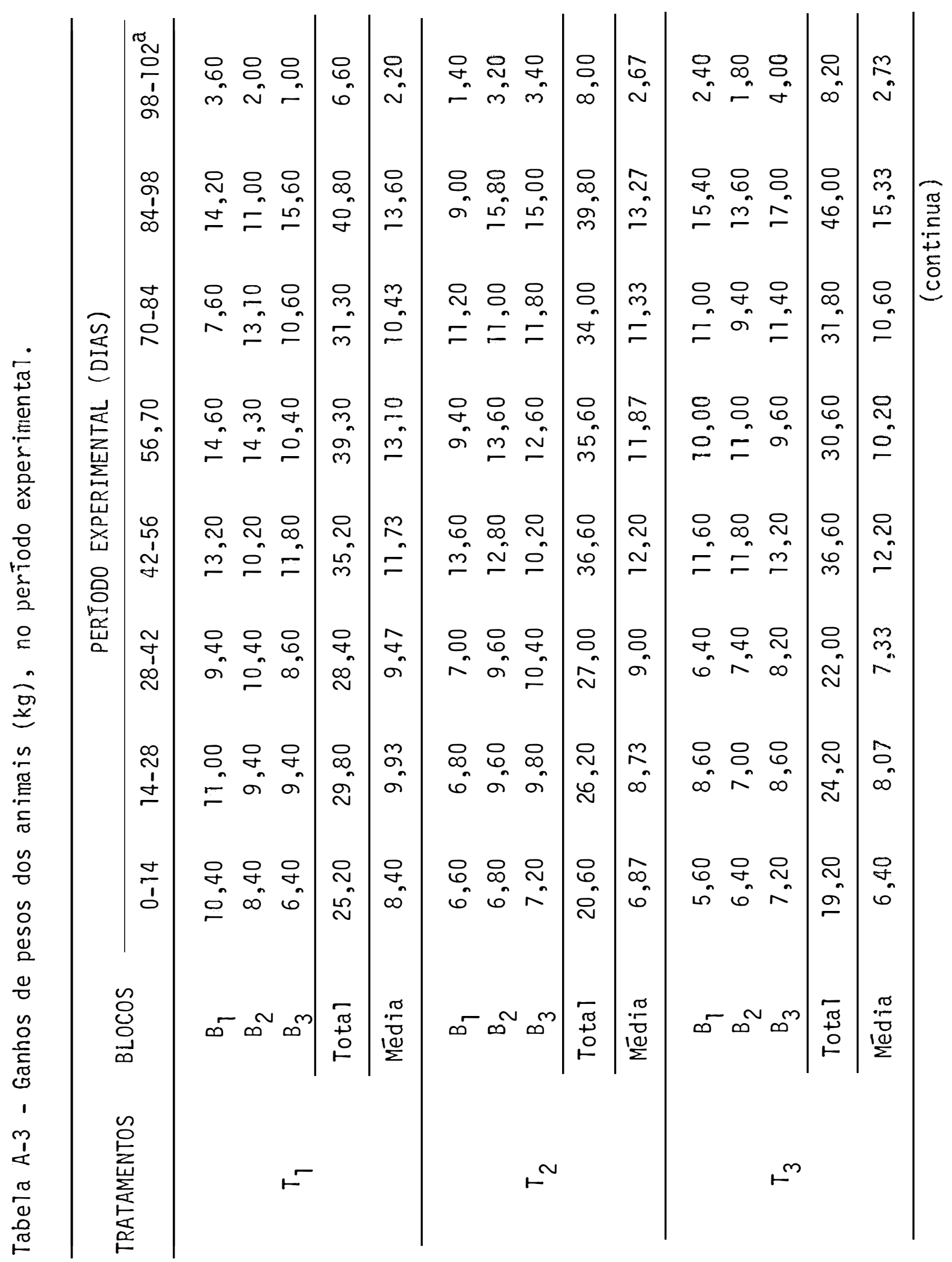


145.

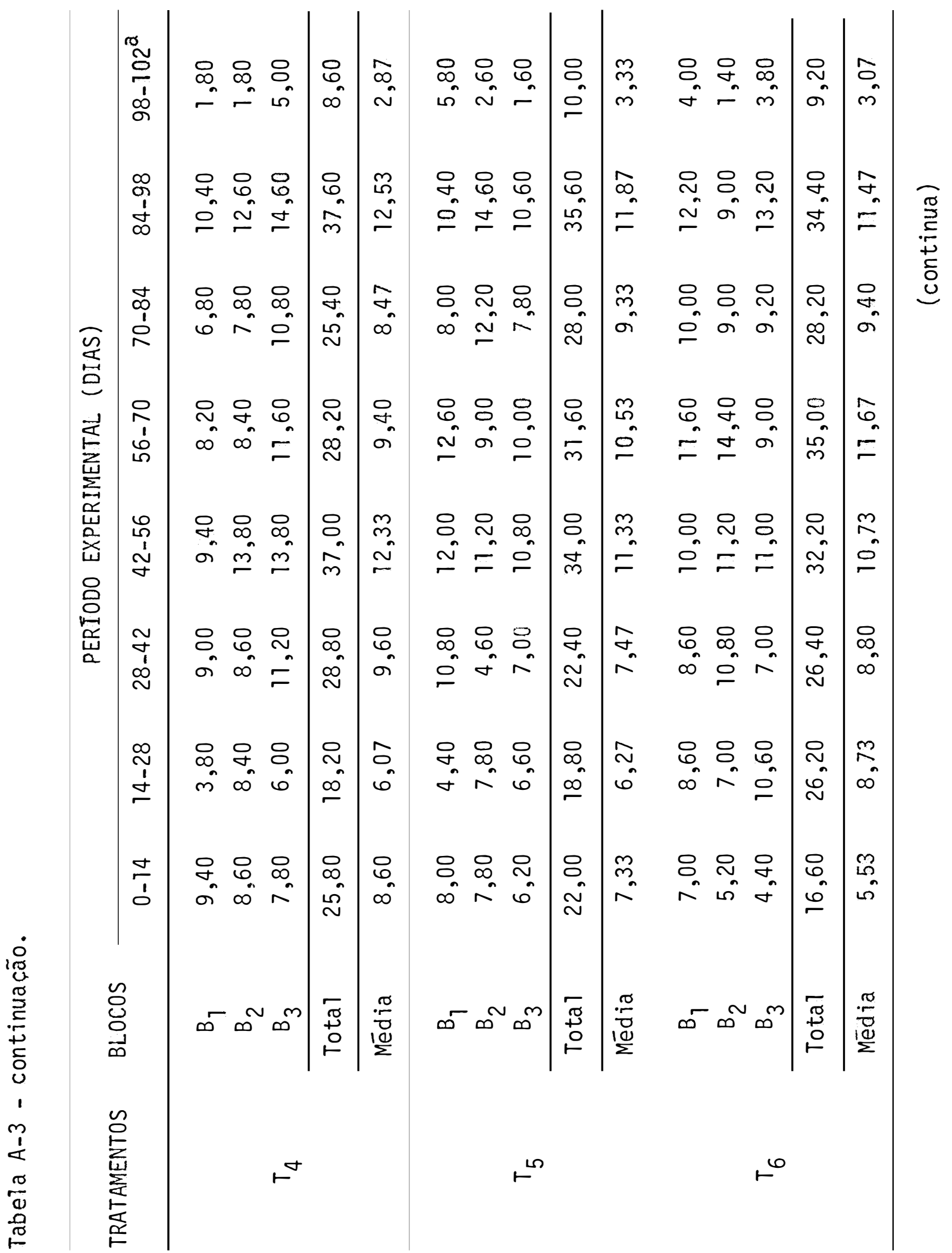


146.

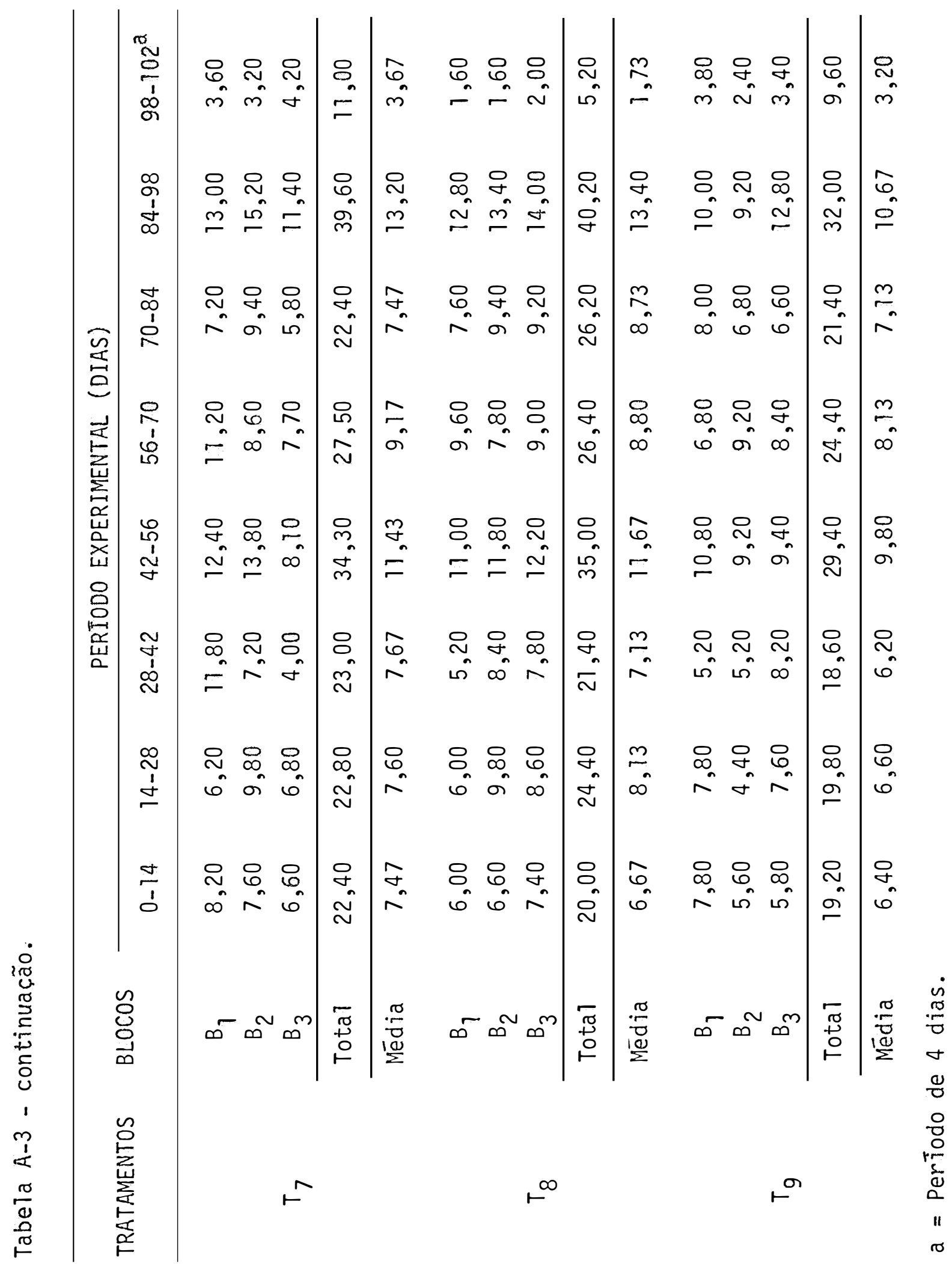




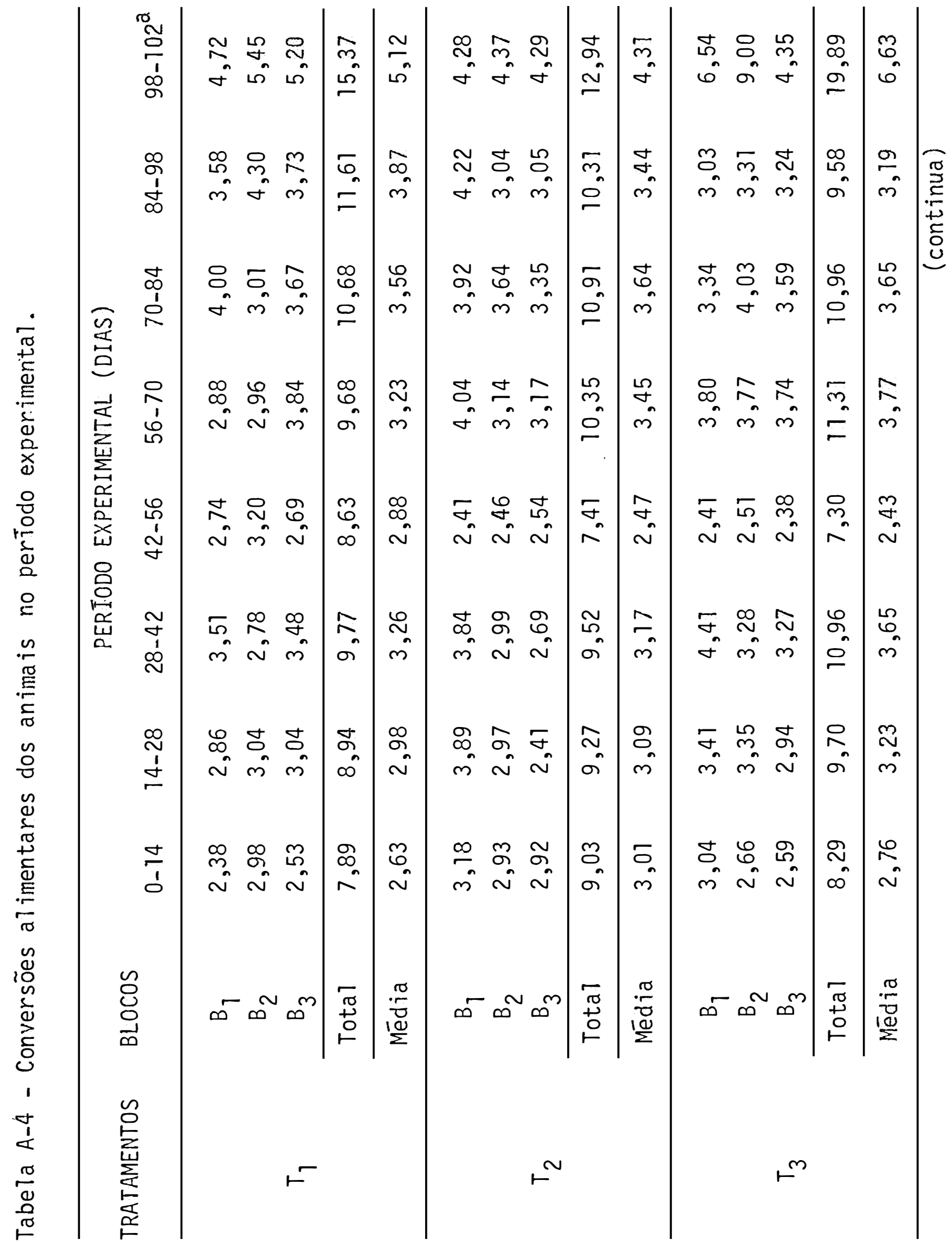


148.

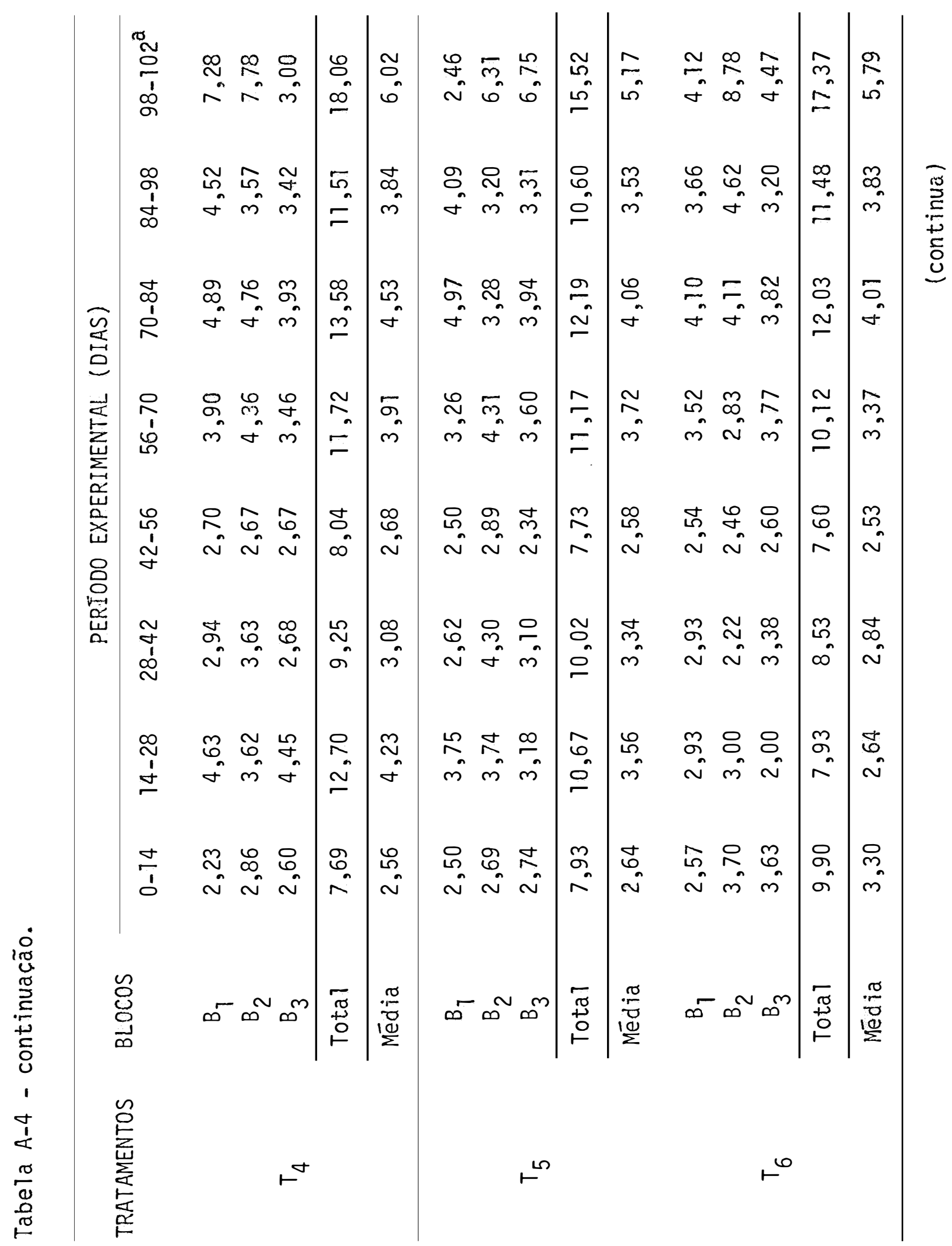




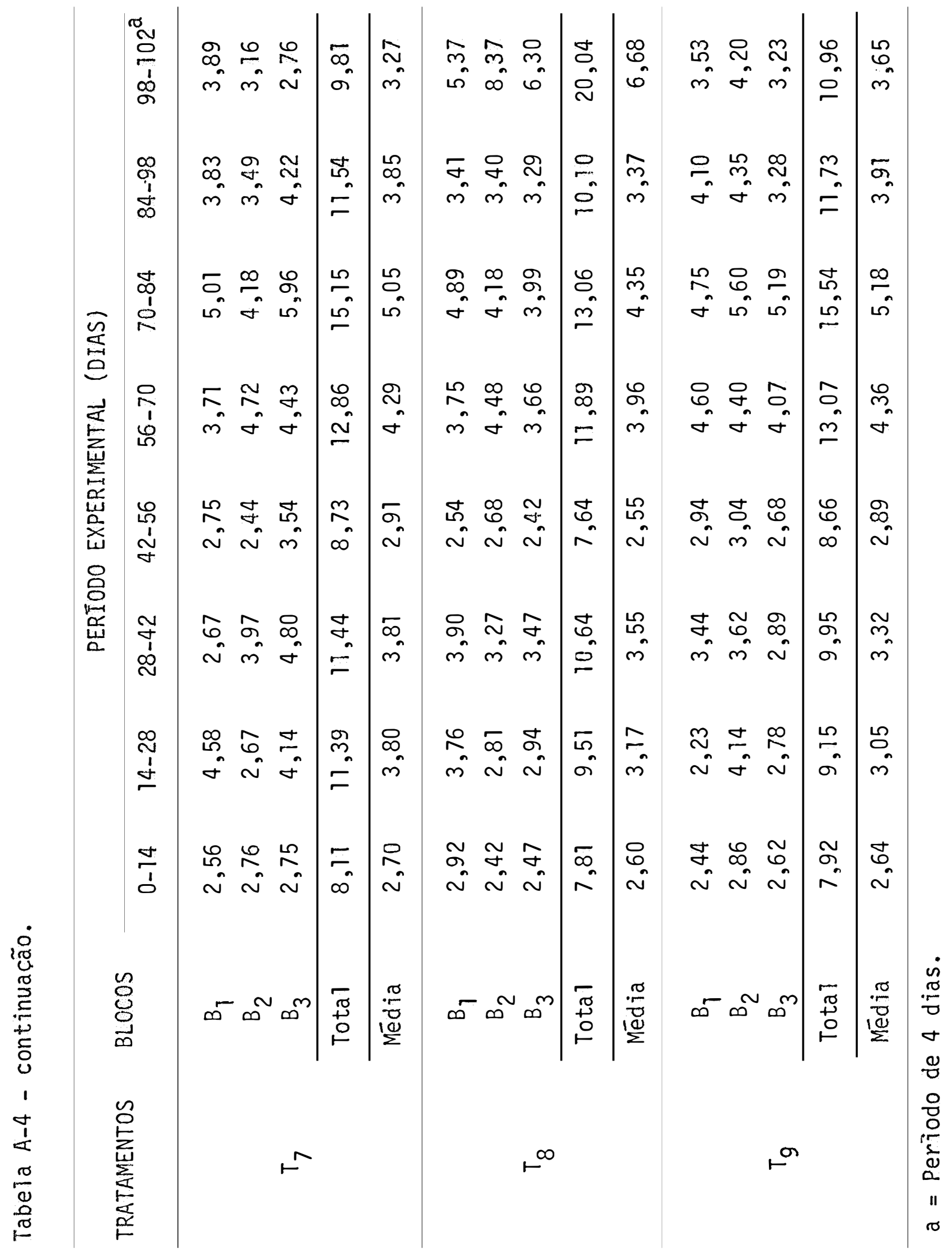


150.

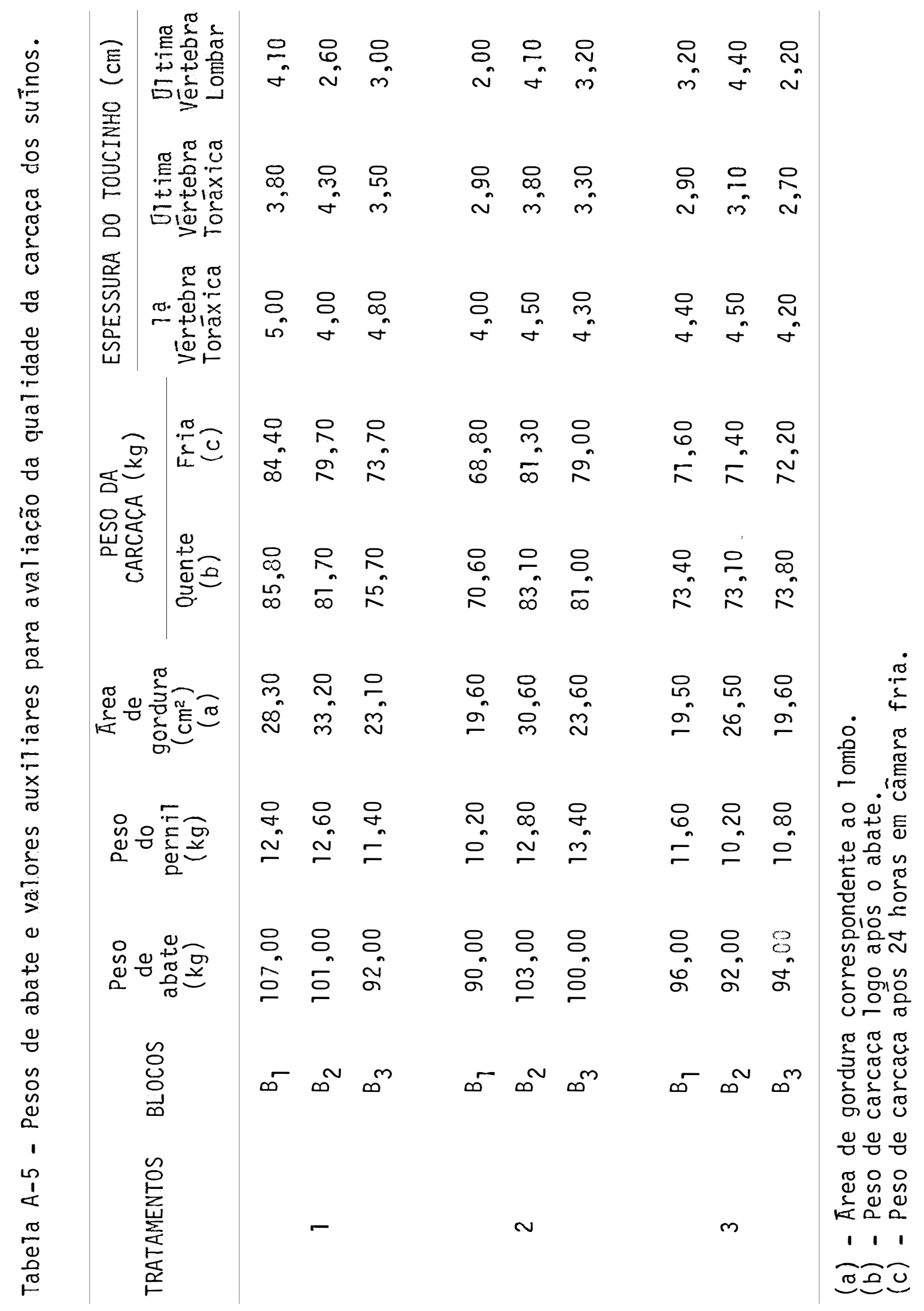


151.

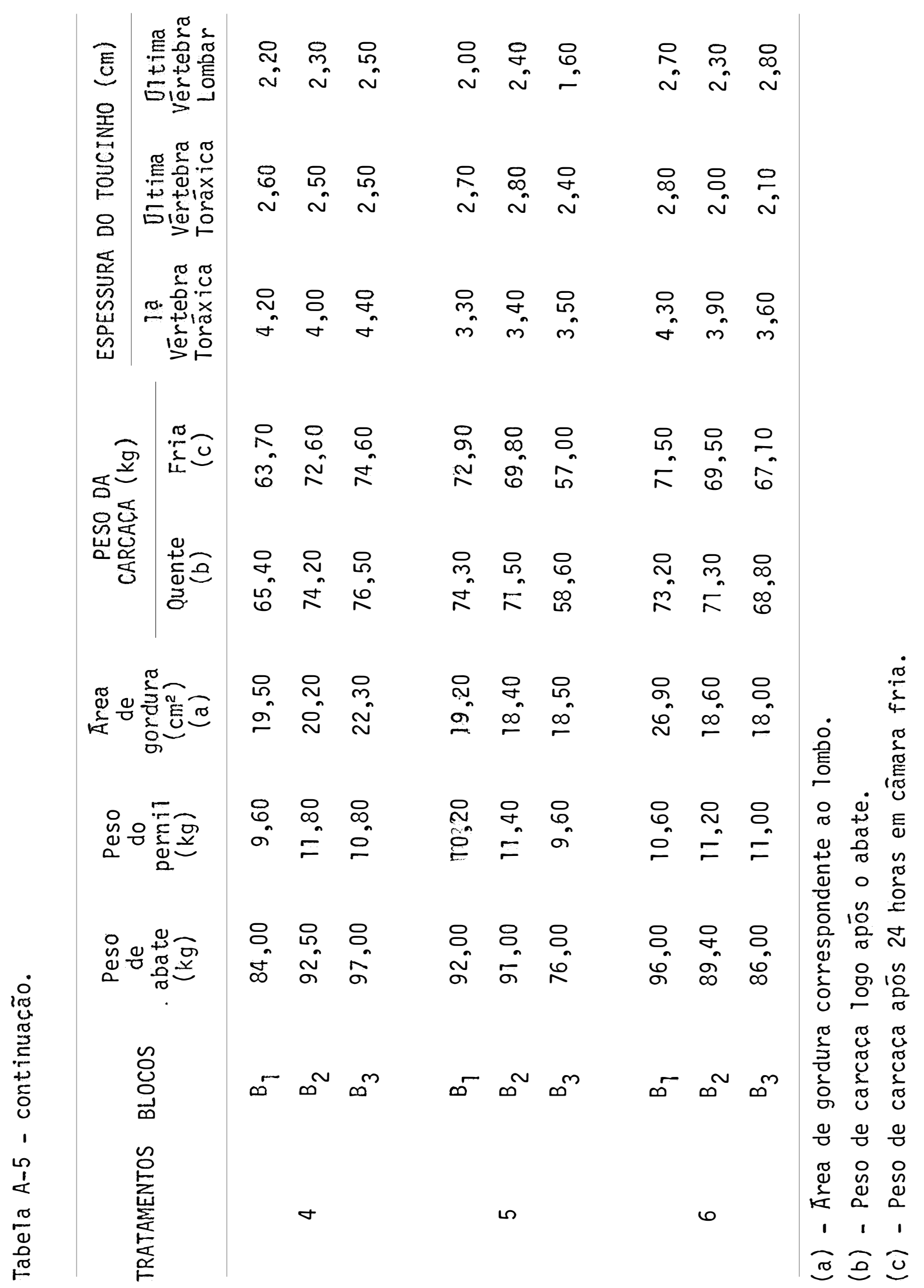


152.

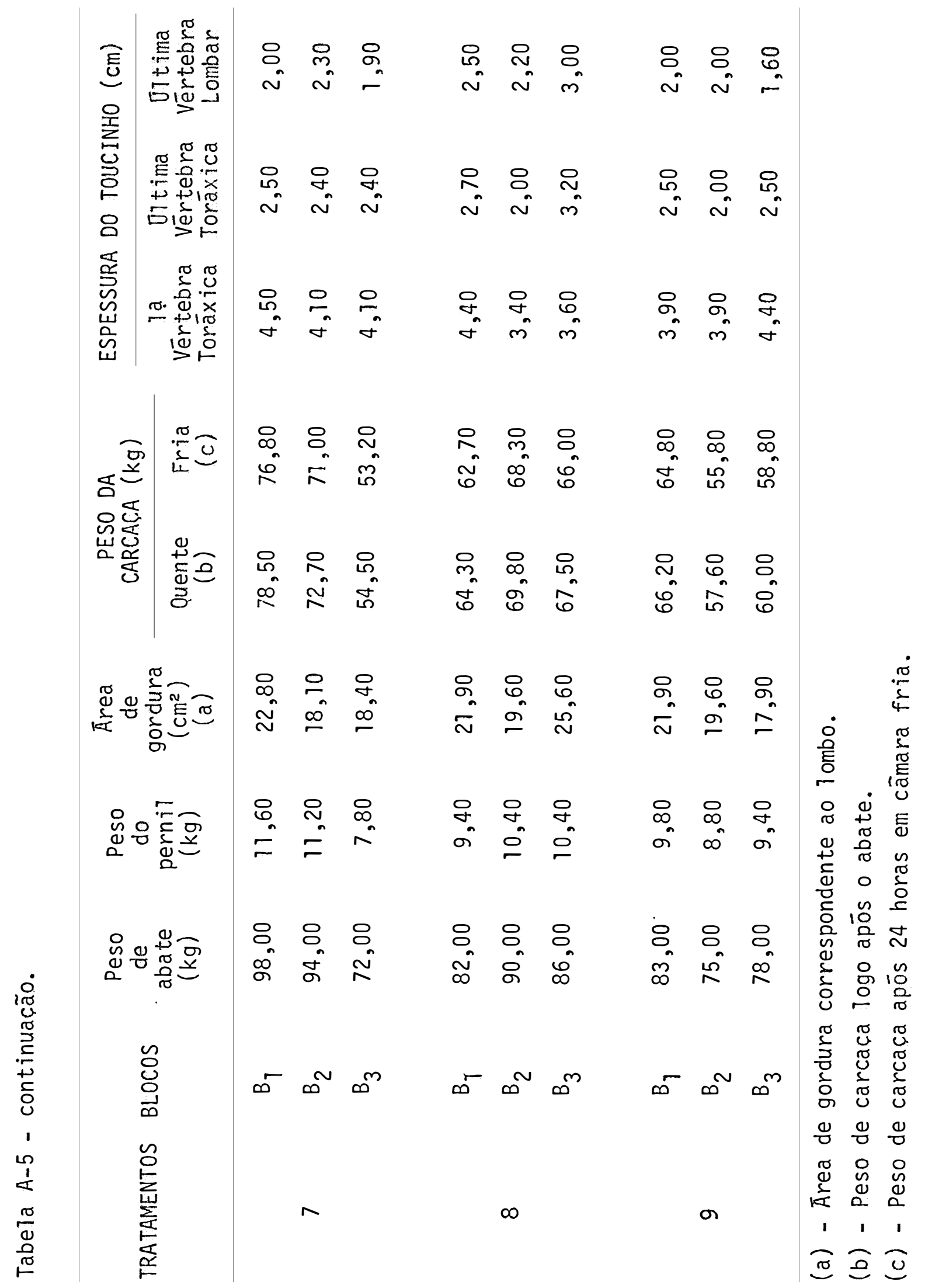

